\title{
HYDROGEOLOGY AND SOIL GAS AT J-FIELD, ABERDEEN PROVING GROUND, MARYLAND
}

By W. Brian Hughes

U.S. GEOLOGICAL SURVEY

Water-Resources Investigations Report 92-4087

Prepared in cooperation with the

U.S. ARMY

ABERDEEN PROVING GROUND SUPPORT ACITIVITY

ENVIRONMENTAL MANAGEMENT DIVISION

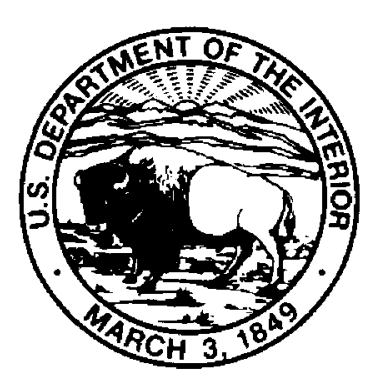

Towson, Maryland 


\section{U.S. DEPARTMENT OF THE INTERIOR \\ BRUCE BABBITT, Secretary \\ U.S. GEOLOGICAL SURVEY}

Robert M. Hirsch, Acting Director

District Chief

U.S. Geological Survey, WRD

208 Carroll Building

8600 La Salle Road

Towson, MD 21286
U.S. Geological Survey--ESIC

Open-File Reports Section

Box 25286, MS 517

Denver Federal Center

Denver, CO 80225 


\section{CONTENTS}

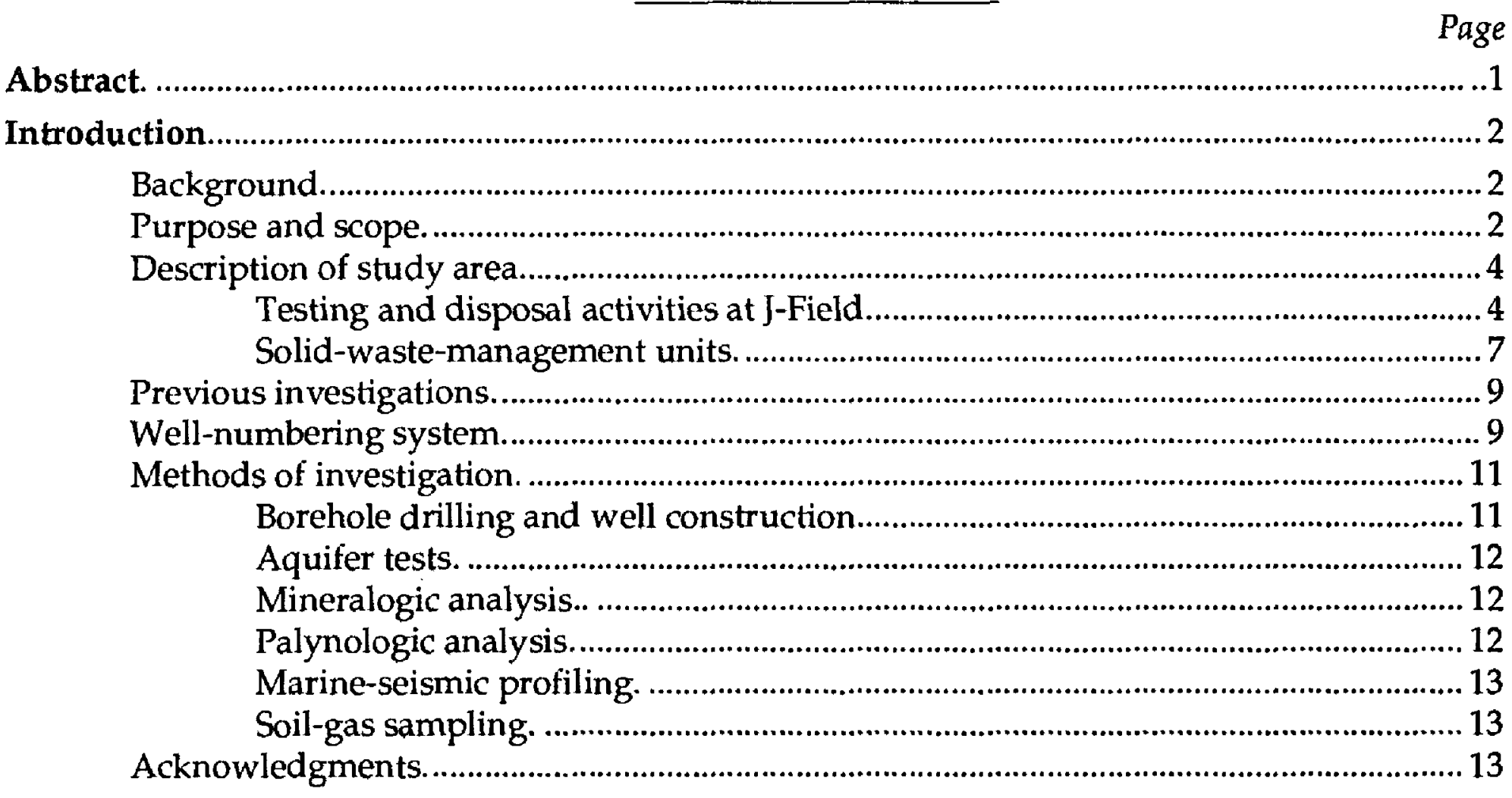

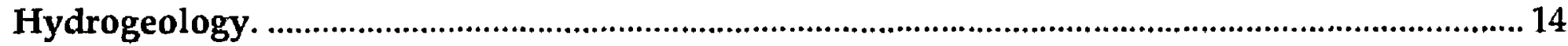

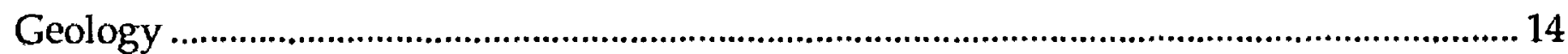

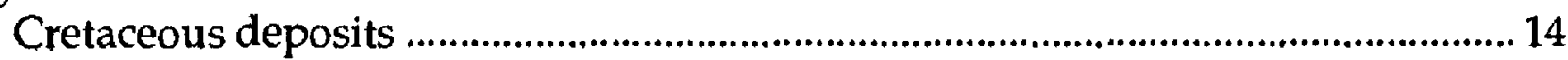

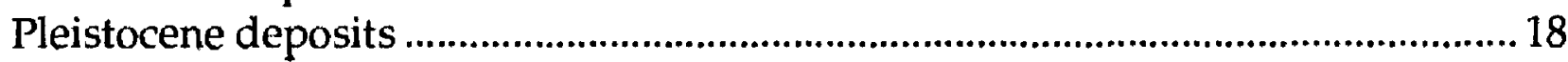

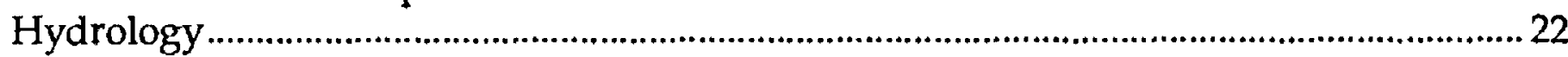

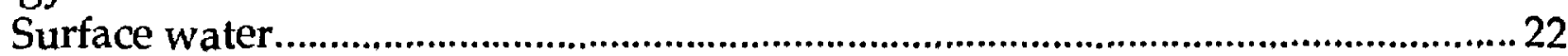

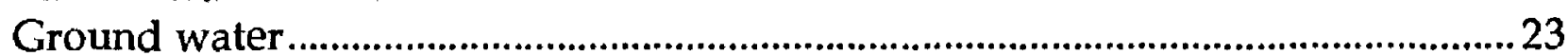

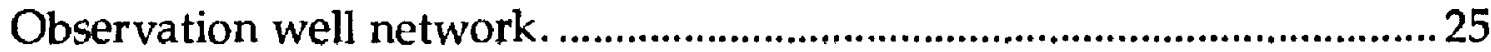

Hydrogeologic units and hydraulic characteristics ....................................2 25

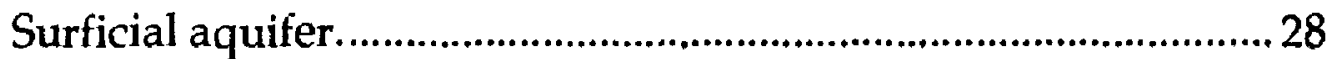

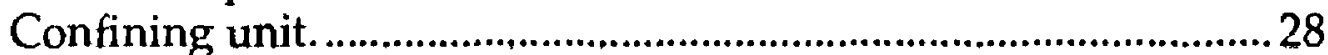

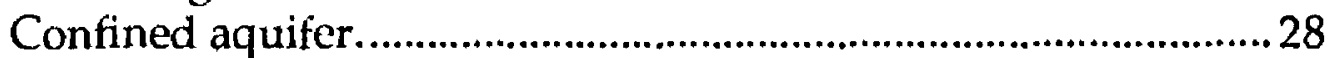

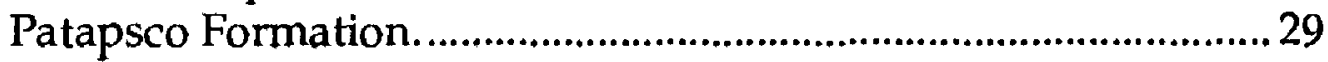

Head distribution and flow directions. ..................................................2 29

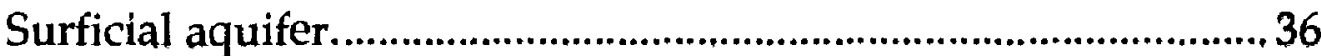

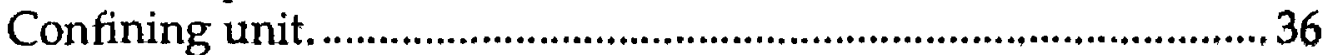

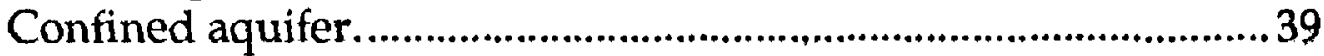

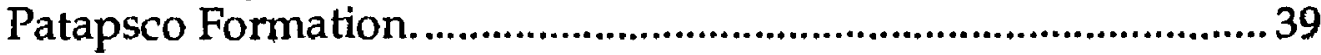

Seasonal and tide-induced fluctuations...................................................41

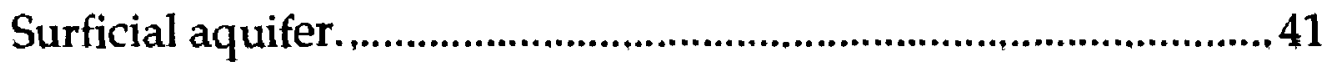

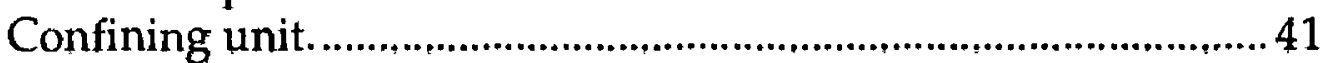

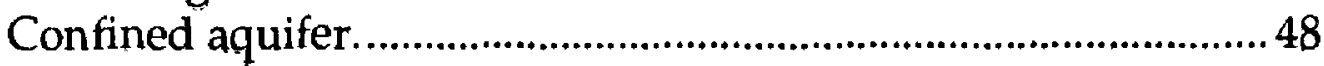

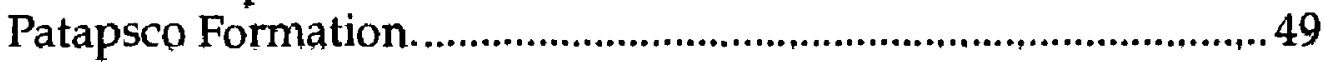




\section{CONTENTS--Continued}

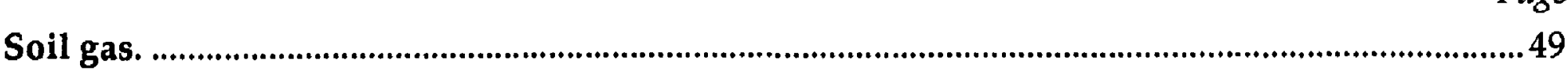

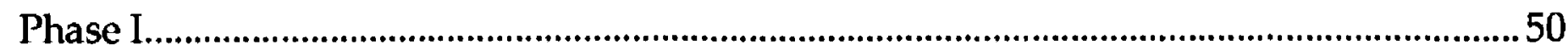

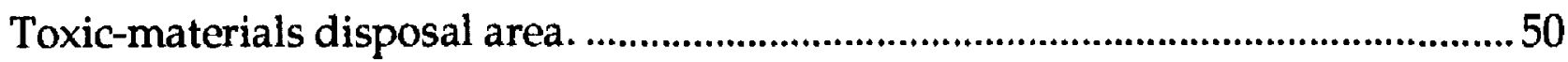

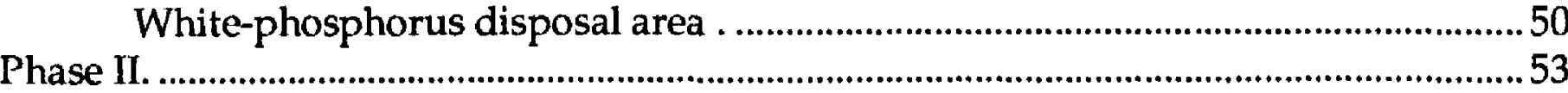

Toxic-materials disposal area. ................................................................................5 53

Dichloroethylene and trichloroethane. .......................................................53

Trichloroethylene and tetrachloroethylene................................................53

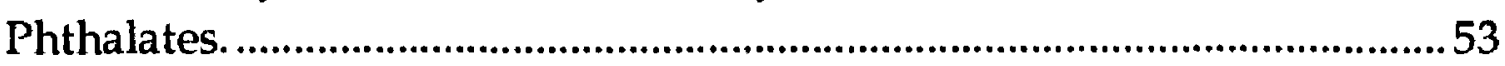

Heavy aromatic hydrocarbons..................................................................5 56

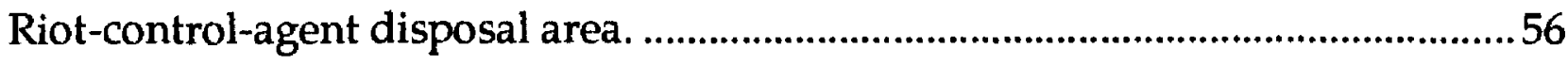

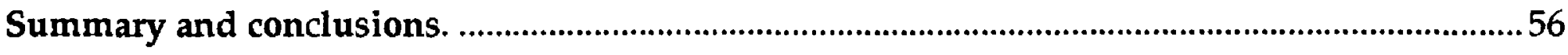

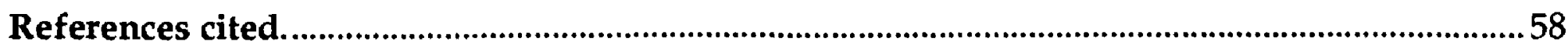

\section{ILLUSTRATIONS}

Figures 1-5. Maps showing:

1. Location of J-Field study area..................................................................................... 3

2. Location of woods, marshes, ponds, and open areas in the

J-Field study area. .................................................................................................5

3. Topography of the study area. .............................................................................. 6

4. Location of solid-waste-management units in J-Field. .....................................8

5. Location of wells drilled during previous investigations at J-Field................ 10

6. Diagram showing construction of typical observation well at J-Field. ....................12

7. Schematic diagram showing geologic units and generalized

direction of ground-water flow in the upper Chesapeake Bay area.................. 15

8. Map showing location of geologic sections. ................................................................ 16

9-10. Geologic sections:

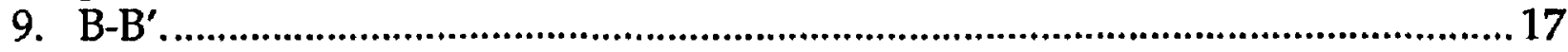

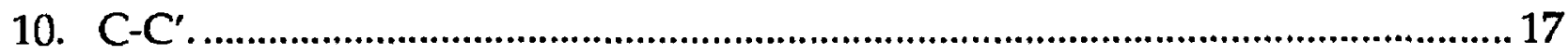

11. Map showing estimated extent of paleochannel deposits, locations of seismic lines, and location of geologic section $D-D^{\prime}$.

12. Geologic section $D-D^{\prime}$ and equivalent seismic profiles from the Gunpowder River.

13. Schematic diagram showing hydrogeologic units and generalized direction of ground-water flow at J-Field. 


\section{ILLUSTRATIONS--Continued}

Figure 14-23. Maps showing:

14. Location of U.S. Geological Survey well clusters and individual well sites

15. Thickness of the surficial aquifer.

16. Altitude of the top of the confining unit.............................................................31

17. Thickness of the confining unit.

18. Altitude of the top of the confined aquifer.

19. Thickness of the confined aquifer.

20. Altitude of the top of the Patapsco Formation. ...............................................35

21. Hydraulic head and direction of ground-water flow in the surficial aquifer, November 1989

22. Hydraulic head and direction of ground-water flow in the confining unit, November 1989

23. Hydraulic head and direction of ground-water flow in the confined aquifer, November 1989

24-29. Graphs showing daily precipitation and water-level altitudes in wells at U.S. Geological Survey:

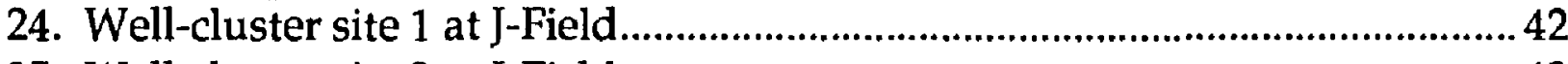

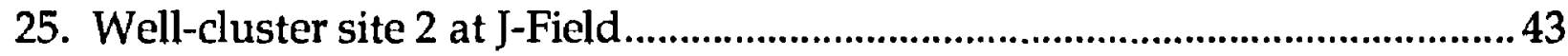

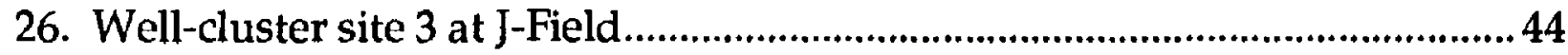

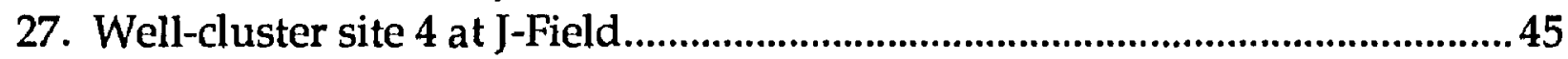

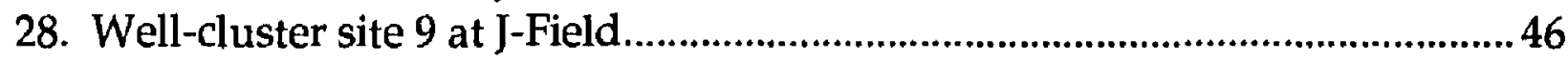

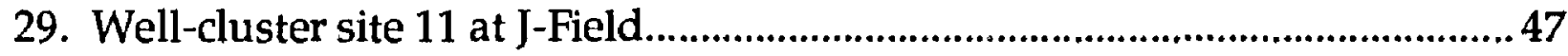

30-31. Hydrographs showing:

30. Tidal fluctuations in the Chesapeake Bay and water-level altitudes in wells $\mathrm{TH} 3, \mathrm{TH} 7$, and $\mathrm{TH} 8$.

31. Water-level altitudes in wells (JF 91, 111, 41, 11,31, 21) screened in in the confined aquifer. Data collected at 15-minute intervals, May 8 to 10, 1991.

32-35. Maps showing:

32. Locations of soil-gas collectors and results of phase I soil-gas analyses at the toxic-materials disposal area:

A. Trichloroethylene relative-flux values;

B. Tetrachloroethylene relative-flux values;

C. Alkane relative-flux values.

D. Combined hydrocarbon relative-flux values;

E. Simple aromatic relative-flux values

33. Locations of soil-gas collectors and results of phase I soil-gas analyses at the white-phosphorus disposal area:

A. Trichloroethylene relative-flux values;

B. Tetrachloroethylene relative-flux values;

C. Simple aromatic relative-flux values;

D. Combined hydrocarbon relative-flux values 


\section{ILLUSTRATIONS--Continued}

32-35. Maps showing:--Continued

34. Locations of soil-gas collectors and results of phase II soil-gas analyses at the toxic-materials disposal area:
A. Combined dichloroethylene and trichloroethane relative-flux values;
B. Combined trichloroethylene and tetrachloroethylene relative-flux values;
C. Phthalate relative-flux values;
D. Heavy aromatic hydrocarbon relative-flux values.

35. Locations of soil-gas collectors and results of phase II soil-gas analyses at the riot-control-agent disposal area:

A. Combined dichloroethylene and trichloroethane relative-flux values;

B. Combined trichloroethylene and tetrachloroethylene relative-flux values;

C. Phthalate relative-flux values;

D. Heavy aromatic hydrocarbon relative-flux values. .55

\section{TABLES}

Table 1. Summary of U.S. Army disposal activities at J-Field..........................................................

2. Relative percentages of minerals in core samples. .......................................................... 19

3. Percentages of major elements present in core samples................................................... 19

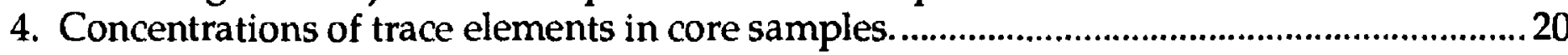

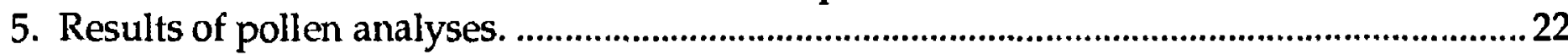

6. Well-construction data for observation wells installed at J-Field. .....................................27

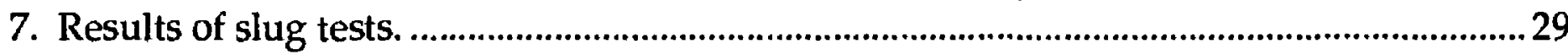

8. Lithologic logs for well-cluster and borehole sites............................................................60 


\section{CONVERSION FACTORS AND VERTICAL DATUM}

\section{Multiply}

inch (in.)

foot $(\mathrm{ft})$

foot per day $(\mathrm{ft} / \mathrm{d})$

mile

mile per hour ( $\mathrm{mi} / \mathrm{hr})$

square inch $\left(\mathrm{in}^{2}\right)$

square foot $\left(\mathrm{ft}^{2}\right)$

\begin{tabular}{c} 
By \\
25.4 \\
0.3048 \\
0.3048 \\
1.609 \\
1.609 \\
6.4516 \\
0.0929 \\
\hline
\end{tabular}

\section{To obtain}

millimeter

meter

meter per day

kilometer

kilometer per hour

square centimeter

square meter

Sea level: In this report, "sea level" refers to the National Geodetic Vertical Datum of 1929--a geodetic datum derived from a general adjustment of the first-order level nets of the United States and Canada, formerly called Sea Level Datum of 1929.

The standard unit for hydraulic conductivity is cubic foot per day per square foot $\left[\left(\mathrm{ft}^{3} / \mathrm{d}\right) / \mathrm{ft}^{2}\right]$. This mathematical expression reduces to foot per day $(\mathrm{ft} / \mathrm{d})$. 


\title{
HYDROGEOLOGY AND SOIL GAS AT J-FIELD, ABERDEEN PROVING GROUND, MARYLAND
}

\author{
By W. Brian Hughes
}

\begin{abstract}
Disposal of chemical warfare agents, munitions, and industrial chemicals in J-Field, Aberdeen Proving Ground, Maryland, has contaminated soil, ground water, and surface water. Seven exploratory borings and 38 observation wells were drilled to define the hydrogeologic framework at J-Field and to determine the type, extent, and movement of ground-water contaminants. The geologic units beneath J-Field consist of the Coastal Plain sediments of the Patapsco Formation (Potomac Group), of Cretaceous age, and the Talbot Formation (Columbia Group), of Pleistocene age. The Patapsco Formation contains several laterally discontinuous aquifers and confining units. The Pleistocene deposits are divided into three hydrogeologic units-a surficial aquifer, a confining unit, and a confined aquifer. Water in the surficial aquifer flows laterally from topographically high areas to discharge areas in marshes and streams, and vertically to the underlying confined aquifer. In offshore areas, water flows from the deeper confined aquifers upward toward discharge areas in the Gunpowder River and Chesapeake Bay.

Analyses of soil-gas samples indicated high relative-flux values of chlorinated solvents, phthalates, and hydrocarbons at the toxic-materials disposal area, white-phosphorus disposal area, and riot-control-agent disposal area. The highest flux values were located downgradient of the toxic materials and white-phosphorus disposal areas, indicating that ground-water contaminants are moving from source areas beneath the disposal pits toward discharge points in the marshes and estuaries. Elevated relative-flux values measured upgradient and downgradient of the riot-controlagent disposal area possibly result from soil or ground-water contamination.
\end{abstract}




\section{INTRODUCTION}

J-Field is located in the Edgewood Area of Aberdeen Proving Ground (APG), Harford County, Maryland, and has been used since World War I for testing munitions. Since World War II, chemical-warfare agents, high-explosive munitions, and industrial chemicals have been tested and disposed of at J-Field (fig. 1). These materials were disposed of by open-pit burning and by high-explosive demolition. Soil and ground-water contamination has resulted from spills of disposal materials and from the migration of unburned chemicals and fuels into the subsurface. Discharge of contaminants from ground water and overland by soil runoff has contaminated surface water in the marshes and estuaries surrounding J-Field. Significant migration of contaminants to the surface-water system creates the potential for adverse effects on wildlife and aquatic populations in the area.

\section{Background}

In 1977-78, soil and ground-water contamination at J-Field was identified during an environmental survey of the Edgewood Area conducted by the U.S. Army Toxic and Hazardous Materials Agency (USATHAMA) (Nemeth and others, 1983). This investigation resulted in the U.S. Environmental Protection Agency (USEPA) issuing a Resource Conservation and Recovery Act (RCRA) permit (MD3-21-002-1355) in 1986. The permit required a hydrogeologic assessment (HGA) to be conducted at J-Field. In May 1987, at the request of the Environmental Management Office of APG, U.S. Department of Defense, the U.S. Geological Survey (USGS) began an investigation to collect the data needed for an HGA of J-Field, the purpose of which was to determine the hydrogeologic framework and to characterize the extent and migration of contaminants in the vicinity of solid-wastemanagement units (SWMU's). The datacollection phase requires an observation-well network to determine directions and rates of ground-water flow, as well as to determine the concentrations and spatial distributions of various chemical constituents in the groundwater system. The data-collection phase also includes soil, sediment, and surface-water sampling to provide information on the concentrations and spatial distribution of chemical constituents in these media.

In 1990, the entire Edgewood Area of APG was added to the National Priority List, placing it under the regulations and guidelines of the Comprehensive Environmental Response, Compensation, and Liability Act of 1980 (CERCLA), also known as Superfund. The current (1991) USGS study at J-Field is part of the Remedial Investigation and Feasibility Study that is required under CERCLA. The purpose of this study is to determine the type and extent of contaminants at J-Field, the hydrogeologic factors controlling migration of the contaminants, and the migration pathways. These data will provide input for a groundwater-flow model that will be used to simulate the effects of proposed remedial actions.

The data for this investigation are being collected in two phases. Data collection has been completed for phase I. The objectives of phase I were to define the hydrogeologic framework and determine the types and extent of contaminants in soil, surface water, and ground water. At this time, data from the chemical analyses are incomplete and are not presented in this report. Data collection for phase II will be used to further define the extent of contaminants by sampling areas where data gaps were identified during analysis of phase I data.

\section{Purpose and Scope}

This report presents the results of the hydrogeologic investigation and soil-gas analyses at J-Field. This is an interim report containing the available data collected during the first phase of the study and interpretations of these data.

During the first phase of the hydrogeologic investigation, 7 exploratory boreholes were drilled and 38 observation wells were constructed in borings at 14 locations. Lithologic descriptions were made of the sediments 


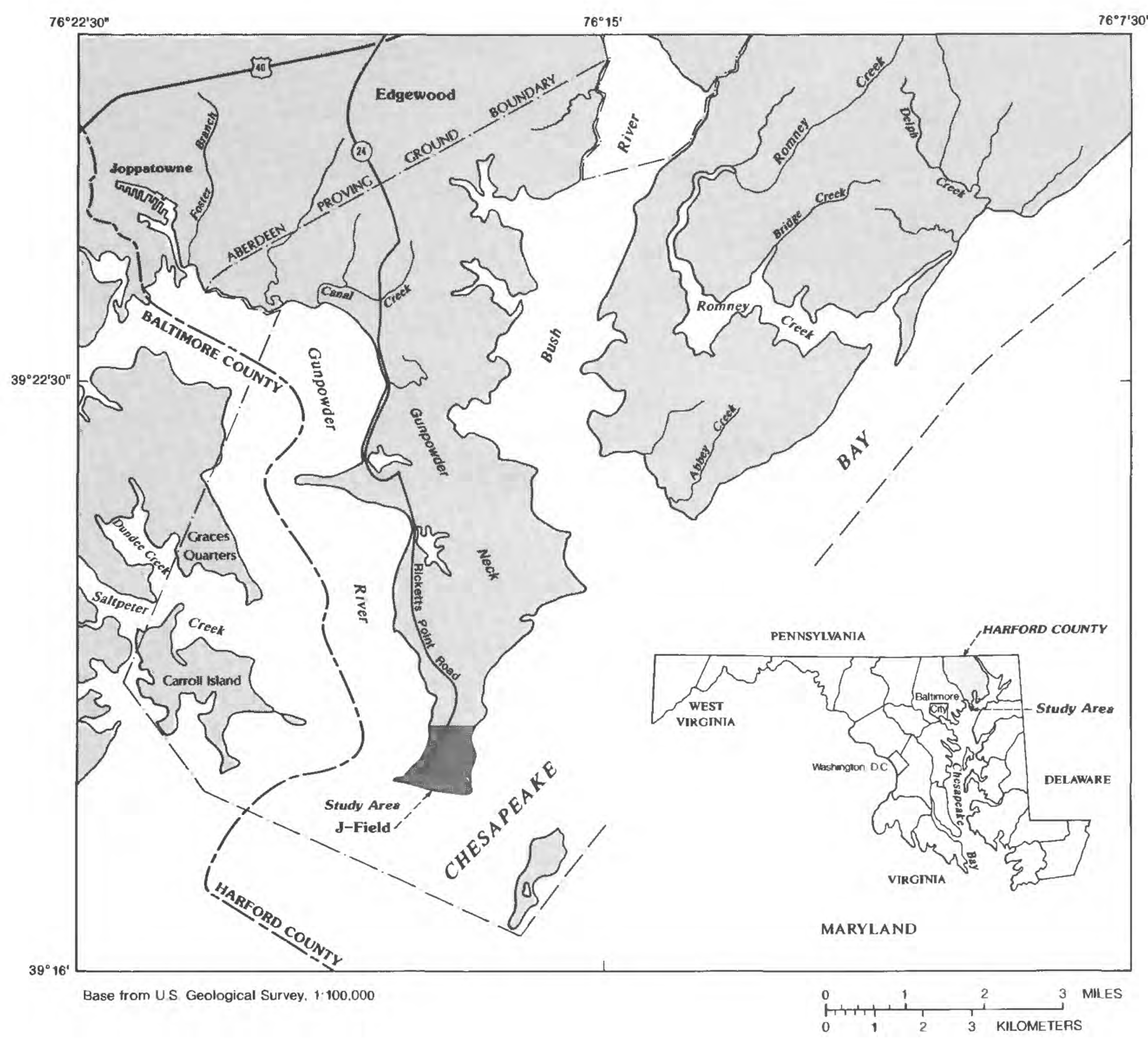

Figure 1.--Location of J-Field study area. 
encountered at each site during drilling and the boreholes were logged using natural-gamma and electric geophysical probes. Selected core samples were analyzed to determine the mineralogy, major elements, trace elements, and pollen content. Geologic sections, lithologicthickness maps, and maps showing the altitude of the tops of the hydrogeologic units were constructed to determine the hydrogeologic framework at J-Field. Approximately $7 \mathrm{mi}$ of single-channel, marine-seismic-reflection data were collected in the estuaries surrounding J-Field and the Gunpowder Neck Peninsula. The marine-seismic data were analyzed in conjunction with the borehole data to map the geometry and extent of the offshore geologic units.

Beginning in 1987, water levels were measured monthly in the 20 wells drilled during previous investigations. The frequency of water-level measurements was reduced to four times a year in 1989, when the 38 USGS wells were completed. Water-level recorders were installed on 5 wells installed during previous investigations in 1987 and on 18 of the wells installed for this study in 1990.

Soil-gas collection tubes were installed during two phases at 134 sites in the areas immediately surrounding the SWMU's. Data from the analyses of the soil-gas collectors were used to draw relative-flux contour maps for selected organic compounds. The first phase of soil-gas data collection was used to identify potential areas of soil and ground-water contamination at the toxic-materials and whitephosphorus disposal areas and to aid in the location of observation wells. The second phase of soil-gas data collection was used to identify areas of soil and ground-water contamination at the riot-control-agent disposal area and to further define the extent of contamination at the toxic-materials disposal area.

\section{Description of Study Area}

J-Field is located at the southernmost end of the Gunpowder Neck Peninsula (fig. 1). The topography is relatively flat. Uplands are located along the western side of the study area approximately $15 \mathrm{ft}$ above sea level and slope gently toward either the shores of the surrounding estuaries or toward marsh areas (fig. 2). At some locations along the shore, wave erosion has produced short, steep cliffs 2 to $10 \mathrm{ft}$ high. Tidal estuaries surround J-Field on three sides: the Gunpowder River on the west and the Chesapeake Bay to the south and east. J-Field contains open fields, second-growth hardwood forest, and nontidal marsh (fig. 3 ).

\section{Testing and Disposal Activities at J-Field}

J-Field has been used since World War I to test high-explosive and chemical munitions. Detailed records of the location and nature of the tests are not available and a summary of the quantities of chemicals released on J-Field is not possible. Nemeth (1989) suggests that, because the chemical agent tests were on such a small scale, there is little possibility of residual environmental contamination by these materials.

During 1940-70, open-pit burning at J-Field was used extensively to dispose of many types of chemical agents, high explosives, and chemical wastes (table 1). Although no records were kept of the quantities and types of chemicals and agents that were disposed of in this manner at $\mathrm{J}$-Field, they probably included various nerve agents, adamsite, riot-control agents, and mustards. In addition, munitions containing these agents, white phosphorus, and high explosives also were disposed of at J-Field. Chemical wastes were primarily those generated from the industrial production of chemical warfare agents at APG and probably consisted of organic solvents. Other materials disposed at J-Field were napalm, liquid-smoke materials, and agent-contaminated storage or manufacturing materials (Nemeth and others, 1983).

The typical procedure for open-pit burning was to place wood in the disposal pit, to add the agents, munitions, and other chemicals, and then to flood the pit with a flammable hydrocarbon fuel, such as fuel oil. The fuel was ignited and containers were opened simultaneously by an explosive charge. 


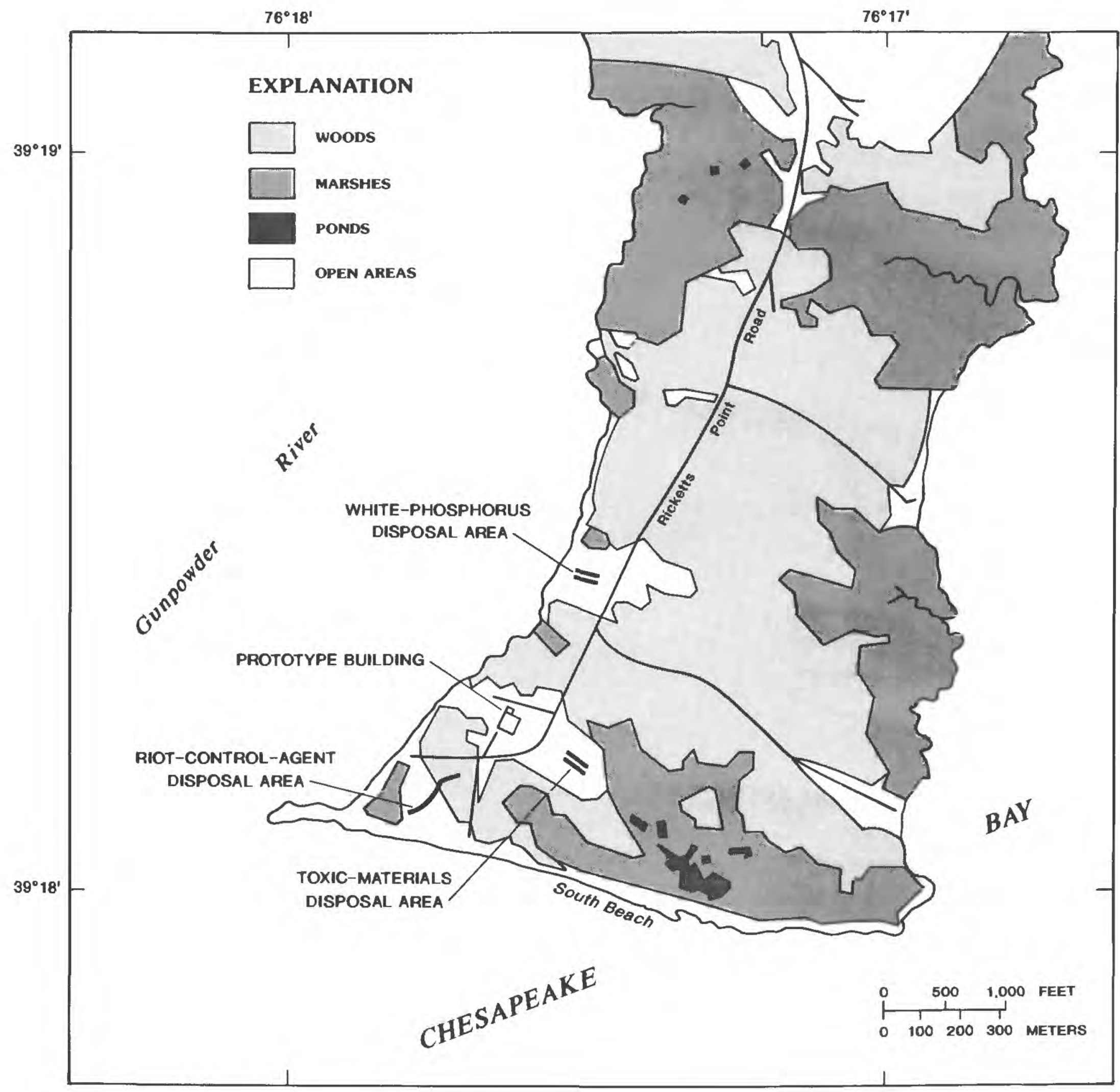

Figure 2.--Location of woods, marshes, ponds, and open areas in the J-Field study area. 


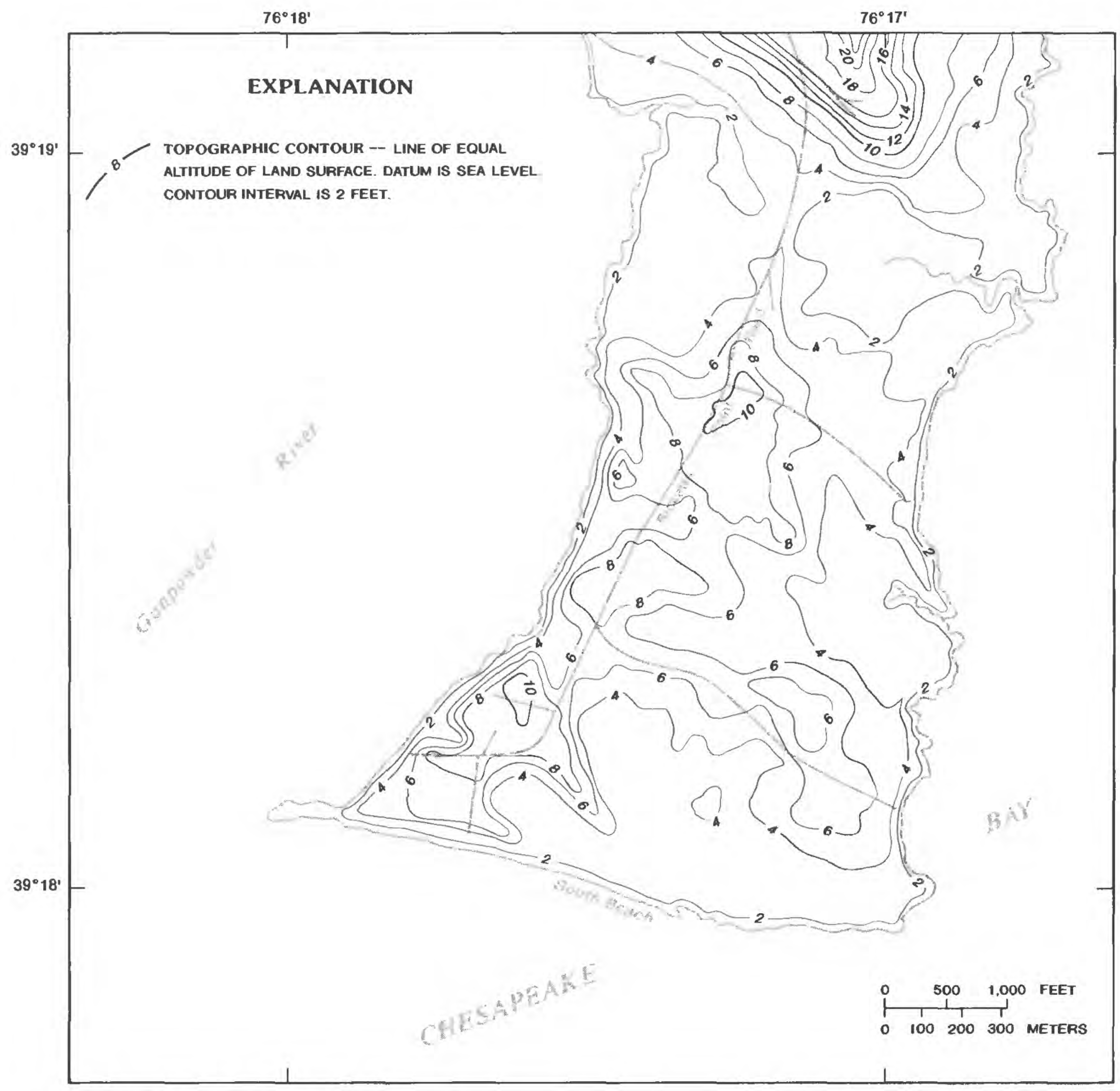

Base from Post Engineer Division. Aberdeen Proving Ground. 1:24,000

Figure 3.--Topography of the study area. 
After the burn was completed, the remaining materials were moved to the adjacent reburn pit, where the process was repeated. After the second burn was completed, any remaining debris was pushed into the adjacent marsh. Some of the liquid materials, such as fuels, organic solvents, and chemical-warfare agents, probably infiltrated into the soil and could have caused soil and ground-water contamination (Nemeth, 1989).

Since about 1970, unexploded ordnance (UXO) discovered during excavations at APG and laboratory chemicals from small-scale testing have been disposed at J-Field. The disposals are conducted by detonating the UXO or laboratory vial with enough high explosive to destroy the chemicals in the resulting fireball.

\section{Solid-Waste-Management Units}

Disposal of hazardous materials were primarily conducted in three SWMU's at J-Field: the toxic-materials disposal area, riot-controlagent disposal area, and white-phosphorus disposal area (fig. 4; table 1). At the toxic materials and white-phosphorus disposal areas, there are two parallel disposal pits approximately $15 \mathrm{ft}$ apart. Each pit is $10 \mathrm{ft}$ deep and approximately $200 \mathrm{ft}$ long by $15 \mathrm{ft}$ wide. Remnants of older pits extend approximately $100 \mathrm{ft}$ into the marsh southeast of the existing pits at the toxicmaterials disposal area. The riot-control-agent disposal area contains a single pit approximately $500 \mathrm{ft}$ long. All of the pits were originally designed so that precipitation that collected in them would drain into the adjacent marsh or river. Since the 1970's, the pits at the toxicmaterials and white-phosphorus disposal areas have been blocked by mounds of soil to prevent drainage from the pits. Water that collects in the pit at the riot-control-agent disposal area drains into the Gunpowder River.

The areas immediately surrounding the pits are clear of trees and brush (fig. 2) and are usually mowed once a year. The area to the east of the toxic-materials disposal area is where unburned materials and soil were pushed out of the disposal pits and into the marsh (the "push-
Table 1.--Summary of U.S. Army disposal activities at J-Field

\begin{tabular}{|c|c|c|c|}
\hline $\begin{array}{l}\text { Solid-waste } \\
\text { management } \\
\text { unit }\end{array}$ & $\begin{array}{l}\text { Material } \\
\text { handled }\end{array}$ & $\begin{array}{l}\text { Period } \\
\text { used }\end{array}$ & $\begin{array}{l}\text { Disposal } \\
\text { practice }\end{array}$ \\
\hline $\begin{array}{l}\text { Toxic-materials } \\
\text { disposal area }\end{array}$ & $\begin{array}{l}\text { High explosives, } \\
\text { nerve agents, } \\
\text { mustards, } \\
\text { smoke } \\
\text { materials, } \\
\text { solvents }\end{array}$ & $\begin{array}{l}1940-80 ; \text { still used } \\
\text { for emergency } \\
\text { emergency } \\
\text { disposal }\end{array}$ & $\begin{array}{l}\text { Open-pit } \\
\text { burning; } \\
\text { detonation }\end{array}$ \\
\hline $\begin{array}{l}\text { White- } \\
\text { phosphorus } \\
\text { disposal area }\end{array}$ & $\begin{array}{l}\text { White } \\
\text { phosphorus, } \\
\text { material } \\
\text { contaminated } \\
\text { with white } \\
\text { phosphorus }\end{array}$ & $\begin{array}{l}\text { 1940-80; still used } \\
\text { for emergency } \\
\text { disposal }\end{array}$ & $\begin{array}{l}\text { Open-pit } \\
\text { burning; } \\
\text { detonation }\end{array}$ \\
\hline $\begin{array}{l}\text { Riot-control- } \\
\text { agent disposal } \\
\text { area }\end{array}$ & $\begin{array}{l}\text { Riot-control } \\
\text { agents }\end{array}$ & $1940-80$ & $\begin{array}{l}\text { Open-pit } \\
\text { burning }\end{array}$ \\
\hline $\begin{array}{l}\text { Prototype } \\
\text { building }\end{array}$ & $\begin{array}{l}\text { Chemical } \\
\text { storage }\end{array}$ & $1940-80$ & None \\
\hline South Beach & Explosives & $1950-80$ & Detonation \\
\hline
\end{tabular}

out" area). The area southeast of the toxicmaterials disposal area contains numerous craters ranging from 5 to $20 \mathrm{ft}$ in diameter and from 5 to $10 \mathrm{ft}$ in depth. These small craters were probably used for burning or demolition (Gary Nemeth, U.S. Army Environmental Hygiene Agency, oral commun., 1988).

The prototype building is a three-story tall, steel-reinforced, open concrete structure that was probably used to store chemicals. Although no records of such use are known to exist, the numerous circular stains on the concrete floor of the building probably resulted from the rusting of storage drums. The prototype building was designed to simulate typical German construction practices during World War II and was used to test the effectiveness of various weapons on such 


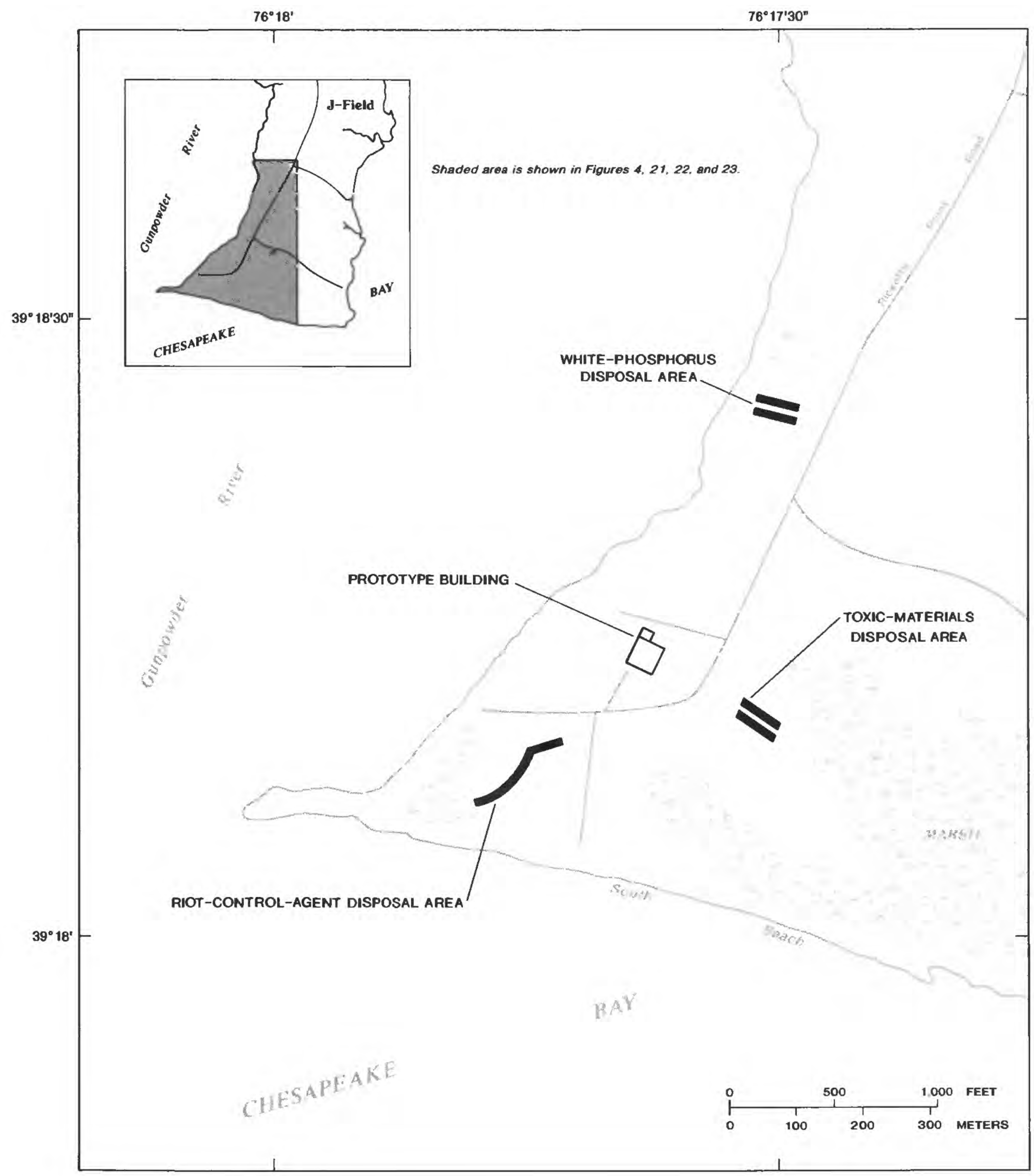

Figure 4.--Location of solid-waste-management units in J-Field. 
structures. A large open field surrounds the prototype building, and a sidewalk extends from the building down to the Gunpowder River. There are no pits or other obvious signs of disposal activities in the immediate vicinity of the prototype building.

The South Beach demolition area was used primarily for the detonation of high-explosive munitions. Because of the high rates of shoreline erosion in this part of J-Field, the South Beach demolition area is now offshore in the Chesapeake Bay. Its presence is marked only by the abundant fragments of munitions that can be observed at low tide. More detailed descriptions of the SWMU's can be found in Nemeth and others (1983) and Nemeth (1989).

\section{Previous Investigations}

The first environmental survey of J-Field was conducted during $1977-78$ by USATHAMA (Nemeth and others, 1983). The study involved conducting a records search, collecting hydrogeologic data, and sampling soil, sediment, ground water, and surface water for chemical analyses. Wells installed for the study were screened approximately $15 \mathrm{ft}$ below land surface (fig. 5). Nemeth and others (1983) concluded that deposits of interbedded sand and clay encountered during test-hole drilling are part of the Cretaceous Potomac Group. Water levels measured in observation wells indicated that lateral ground-water flow was from the upland areas toward the adjacent rivers or marsh, and that the water table generally followed the configuration of the land surface. Soil, borehole sediment, and surface-water samples collected during the study did not contain any contaminants. Ground-water samples contained low concentrations of volatile organic compounds. On the basis of low or undetectable concentrations, Nemeth and others (1983) concluded that the concentrations of contaminants at J-Field were not a threat to the environment and that future monitoring was not necessary.

A munitions-disposal study was conducted in 1983 by Princeton Aqua Science (1984) to evaluate the environmental effects of the disposal operations at J-Field. The study involved site inspections, interviews with appropriate site operations personnel, and field investigations. Nine observation wells (fig. 5) were installed. During drilling, sediment samples were collected and analyzed for chemical constituents. Borehole sediment samples at the toxic-materials disposal area were found to contain concentrations of arsenic, cadmium, lead, and mercury that were higher than those in adjacent areas. After the wells were completed, ground-water samples were collected and analyzed for chemical constituents. Ground-water samples collected from wells at the toxic-materials disposal area exceeded the 1983 USEPA primary drinking-water regulations for nitrates, coliform bacteria, and gross-beta radiation. USEPA secondary drinking-water regulations for chloride, iron, manganese, and sulfate also were exceeded. At the whitephosphorus disposal area, the primary drinkingwater regulation for coliform bacteria concentrations was exceeded and the secondary regulations for iron and sulfate were exceeded. The study concluded that the burning operations were not adversely affecting ground-water quality, however, and the disposal practices did not need to be substantially altered (Princeton Aqua Science, 1984).

The RCRA Facility Assessment (Nemeth, 1989) contains the most comprehensive information available on the disposal of chemicals in the study area. The report presents a review and summary of previous work at J-Field and recommends continued investigation at the toxicmaterials disposal area, white-phosphorus disposal area, riot-control-agent disposal area, prototype building, and South Beach area.

\section{Well-Numbering System}

Wells constructed for the Princeton Aqua Science study are numbered P1 to P9, and the wells constructed for the USATHAMA study are numbered TH1 to TH11 (fig. 5). Seven exploratory boreholes were drilled for the USGS study and are numbered B1 to B7. Observation wells were constructed in exploratory boreholes B6 and B7 and are numbered JF1 and JF2. 


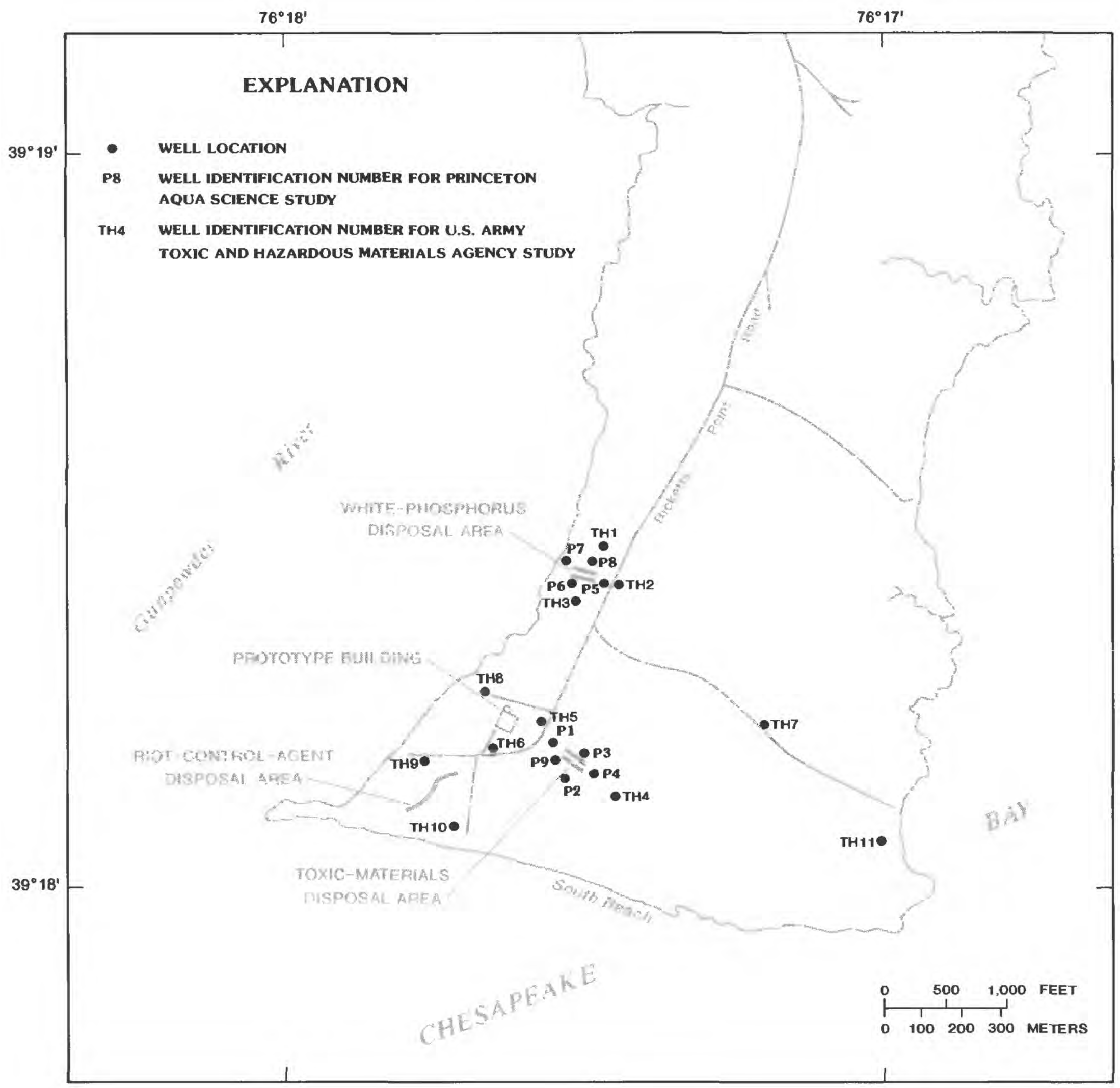

Figure 5.--Location of wells drilled during previous investigations at J-Field. 
Groups of 3 observation wells were constructed at 12 sites in J-Field. These are referred to as USGS well-cluster sites 1 to 12 . The numbers of the individual wells at the cluster sites begin with the prefix JF, followed by the cluster-site number and a number that indicates the relative depth of the well. This last number is 1 for the deepest well at each site, 2 for the intermediate depth well, and 3 for the shallowest well. For example, the deepest well at USGS well-cluster site 9 is JF91, the intermediate-depth well is JF92, and the shallowest well is JF93.

\section{Methods of Investigation}

Techniques used to define the hydrogeologic framework included making geologic borings, installing observation wells, conducting aquifer tests, analyzing geologic materials for their mineral and pollen content, and collecting marine-seismic data. Soil-gas sampling and analysis was used to map the types and extent of soil contamination and to give an indication of areas where ground water is contaminated.

\section{Borehole Drilling and Well Construction}

Seven exploratory boreholes were drilled to a depth of approximately $300 \mathrm{ft}$ below land surface to define the subsurface hydrogeologic framework. The wells were drilled with the mud-rotary technique, and drill cuttings were collected from the mud returning at the top of the borehole by means of a sieve. Split-spoon samples were collected when formation changes were determined from the well cuttings or from changes in the drill-rig response, such as a change in the penetration rate. The boreholes were logged using natural-gamma and electric geophysical probes. After completion of the drilling, five exploratory boreholes were filled to land surface with cement grout. Observation wells were constructed in two of the boreholes.

Thirty-six observation wells were installed in shallow 10-in.-diameter boreholes that were drilled with a continuous-flight hollow-stem auger rig. Undisturbed core samples were continuously collected as each 5 -ft section was drilled. Samples of the core were collected at selected intervals to determine the mineralogy and palynology of the geologic sediments.

Because the auger flights served as a temporary well casing, drilling mud was not used.

All the wells were constructed using 4-in.o.d.(outside diameter) polyvinyl chloride (PVC) well casing (fig. 6). Well screens were made of 4in.-o.d. wire-wrapped stainless steel. Stainless steel was used as a screen material because of concerns for the resistance of PVC screen in contact with various organic compounds that might be present in the aquifers. The casing and well screen were threaded so that no glues or solvents were used in the well construction. A filter pack of medium-sized quartz sand was installed by tremie pipe from the bottom of the borehole to $1 \mathrm{ft}$ above the top of the well screen. A 2-ft-thick layer of bentonite clay pellets was added to prevent grout penetration into the filter pack. Cement grout containing 5-percent bentonite was then added through a tremie pipe, filling the annular space between the borehole and casing from the bentonite seal to land surface. If the grout subsided more than a few feet below land surface after drying, more of the cement-bentonite mixture was added to bring it close to land surface. A square steel protective casing with sides 6 in. in length was placed around the well casing and embedded in a bentonite slurry. The bentonite prevents water from leaking around the well casing but is not destroyed by frost heaving. A 4-ft cement pad was placed around all the finished wells.

The wells were developed with an air-lift system until either clean water was pumped from the well or, for extremely low-yielding wells, three well volumes of water were removed. Water levels in wells screened in the confining unit were lowered to the screen and pumping had to be stopped to allow the water levels in the wells to recover. Development of these wells may not have been as complete as for the wells with higher yields. The purged water was sampled for volatile organic compounds and then taken to the Edgewood sewage-treatment facility for disposal. 


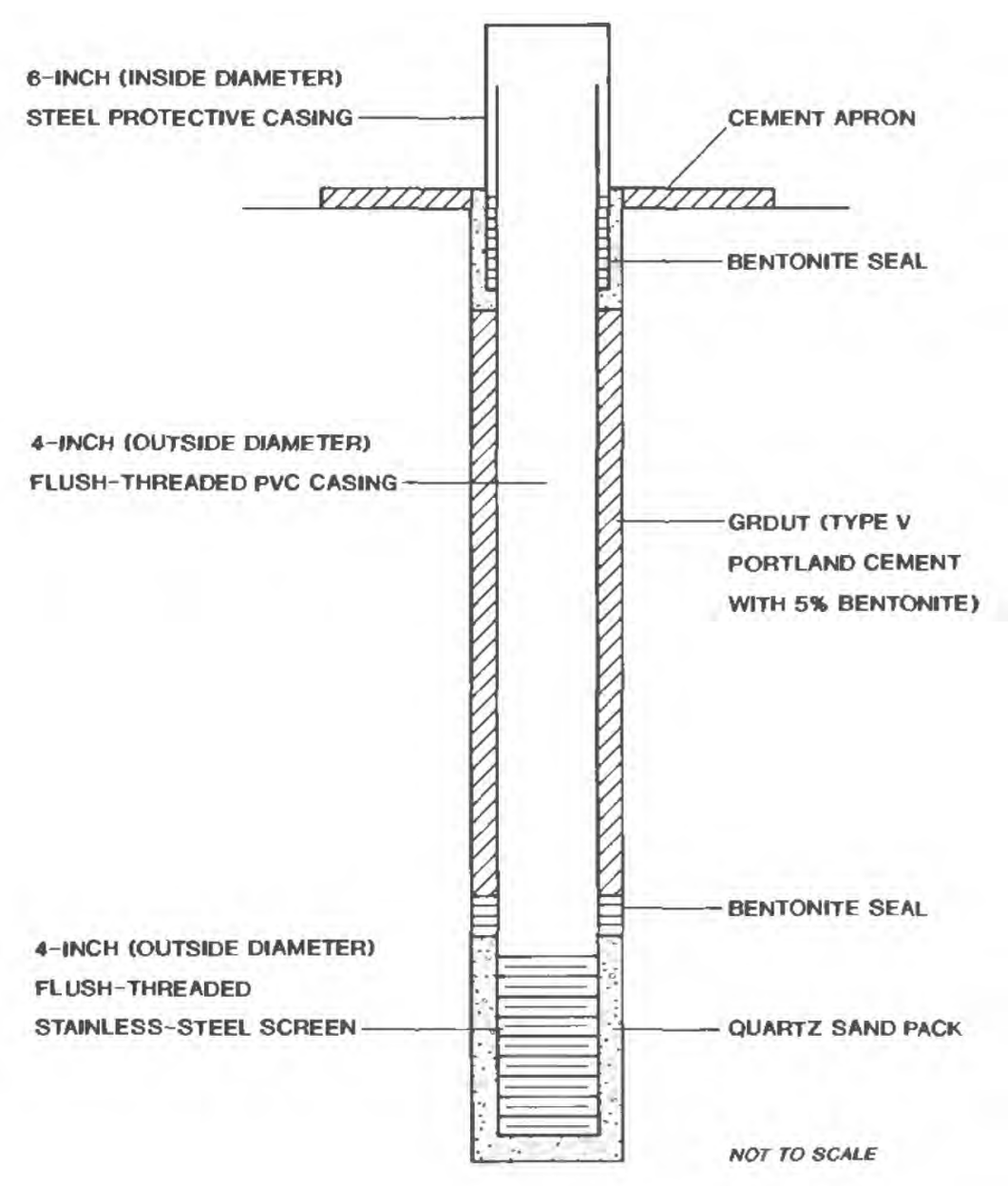

Figure 6.-- Construction of typical observation well at J-Field.

\section{Aquifer Tests}

Slug tests were conducted on 12 of the wells constructed for this investigation. A Teflon ${ }^{1}$ slug was used to displace water in the well and a pressure transducer was used to measure changes in water levels for the tests. A programmable data logger was used to collect the data and was equipped with a printer. Initial water-level measurements were made with a graduated steel tape and were used to calibrate the pressure transducer and data logger to $0.01 \mathrm{ft}$. During the test, changes in water levels were recorded more often at the beginning of the tests and less often toward the end. A typical test began with five measurements per second for the first 6 seconds and ended with one measurement every 10 minutes. The data were analyzed with a straight-line method (Hvorslev, 1951) and a curve-matching technique (Cooper and others, 1967).

\section{Mineralogic Analysis}

The mineralogy of core samples collected at selected intervals during drilling was analyzed using X-ray diffraction techniques by the Branch of Geochemistry, Geologic Division, USGS, Denver, Colo. The samples were split at the laboratory to obtain a representative sample and were ground to pass a 200-mesh sieve. A solution made by mixing the powdered sample with water was pipetted onto a glass microscope slide and allowed to dry. The finished slides were placed on a diffractometer and scanned from 4 to 70 degrees $2-\theta$, using nickel-filtered copper $\mathrm{K}-\alpha$ radiation. A semiquantitative analysis of the mineralogy was obtained by evaluating the peak heights on the resulting diffractogram. The results are presented as relative percentages of total minerals detected.

\section{Palynologic Analysis}

An analysis of the pollen preserved in the stratigraphic record can give an indication of the climate at the time of deposition and the geologic age of the unit. Six of the selected core samples were analyzed for their pollen content at the Department of Geography and Environmental Engineering, Johns Hopkins University, Baltimore, Md. Representative samples from each lithologic unit were examined to determine the types and relative amounts of pollen. All samples were treated with hydrochloric acid, hydrofluoric acid, and acetylyzed with a combination of sulfuric acid and acetic anhydride. Samples were then washed with glacial acetic acid, water, and ethanol, and stored in tertiary butyl alcohol. Identifications and counts were made under 400X magnification (G.S. Brush, Johns Hopkins University, written commun., 1989). The results are reported as the percentage of pollen present.
1. Use of brand names in this report is for identification purposes only and does not constitute endorsement by the U.S. Geological Survey. 


\section{Marine-Seismic Profiling}

Marine-seismic profiles were run in the estuaries surrounding J-Field to determine the geometry of the geologic units in offshore areas. The subbottom-profiling system was manufactured by Ferranti-Ocean Research Equipment and consists of a transmitter (Model $5430 \mathrm{a}$ ), a receiver (Model 5210a), and an array of four transducers (Model 3610a). The transmitter and receiver control the outgoing voltage to the transducers and amplify and filter the returning signal. The filters are used to select the frequency range that provides the sharpest and clearest record with the least amount of interference. The transducers function as both the transmitter and receiver of the acoustic pulse. The transducers provide output frequencies of $3.5,4,7$, and $14 \mathrm{khz}$ (kilohertz) and can function in two modes: two transducers transmit and two receive, or four transducers transmit and four receive. A thermal graphic recorder manufactured by EPC (Model 8700) was used to produce a continuous profile of the reflecting horizons and also generated the pulse interval for firing the transducers. A gasoline-powered electric generator was used to provide the alternating current for the electronic equipment. A four-channel, reel-to-reel tape recorder was used for recording unfiltered returning signals for playback and signal processing.

A long-range navigation (loran) system was used to position the seismic lines geographically. Loran is a land-based radio-navigation system that gives geographic location in either loran coordinates or latitude and longitude. The loran unit is self-calibrating and is generally accurate to about $100 \mathrm{ft}$. As the seismic lines were run, the loran coordinates were periodically recorded on the graphic record so that the lines could be plotted on a map.

An 18-ft-long outboard-powered workboat was used for the seismic study. The surveys were made at a speed of 3 to 5 miles per hour $(\mathrm{mi} / \mathrm{hr})$ with the transducer unit lowered alongside the boat. Although other frequencies were available, $3.5 \mathrm{kHz}$ was used almost exclusively because reflections were sharper and less interference was generated on the record at this frequency. The frequency that provides the best record is site-dependent and is determined by trial and error in the field.

\section{Soil-Gas Sampling}

Analyses of soil gas can provide a relative measure of the areal distribution of contaminants and can aid in determining locations for well drilling and soil sampling. Soil gas was collected using Petrex collection tubes and was analyzed by Northeast Research, Inc., Farmington, Conn. An individual Petrex tube consists of a 6-in.-long open-ended glass tube that contains a carboncoated steel wire. The tubes were buried in the soil at a depth of approximately $10 \mathrm{in}$., with the open end at the bottom. Volatile organic compounds were trapped in the tube as they diffused upward through the soil and were sorbed onto the carbon-coated wire. At selected time intervals, calibration tubes were pulled from the soil and sent to the laboratory for analysis. When the calibration tubes contained a sufficiently high concentration of volatile organics, all the tubes were removed and sent to the laboratory. The concentrations of volatile organics were identified by mass spectrometry and are expressed as ion counts or relative-flux values.

The Petrex static-collection technique provides a time-averaged semiquantitative value for the organic compounds present in the soil gas. The values are reported as ion counts or relative fluxes and are only comparable to values measured during the same sampling interval. The source for the volatile organics could be located in either the unsaturated or saturated zone, and could result from a surface spill or from migration of contaminated ground water.

\section{Acknowledgments}

Many people contributed to this investigation. Thanks are given to U.S. Army personnel, including: John Wrobel of the Directorate of Safety Health and Environment, for logistical support; SGT Bert Rhodes and LT Gary Grimm of the Technical Escort Unit for their help during drilling; Mark Fisher and SGT Rick Bolding of the Technical Escort Unit for help with daily field operations; and Ken Deptol of the Combat Safety Testing Agency for keeping us out of danger. John Bush, Eddie Woods, and 
Will Sanders of the U.S. Army Corps of Engineers deserve thanks not only for installing the observation wells, but also for assisting in removing stuck vehicles, fabricating field equipment, and for always being available to solve problems. The author is grateful to Dr. Grace Brush of Johns Hopkins University for identifying and interpreting pollen samples, and to Mark Hatheway of Northeast Research, Inc., for assisting with the soil-gas analyses.

\section{HYDROGEOLOGY}

The regional flow system in the upper Chesapeake Bay region consists of recharge on the eastern and western shores of the Chesapeake Bay with lateral flow toward, and discharge into, the Bay (Otton and Mandle, 1984) (fig. 7). On the western shore, precipitation recharges the Cretaceous deposits and ground water generally flows downdip toward the east. On the Eastern Shore, Pleistocene units are recharged by precipitation, and ground water flows vertically downward through Tertiary and Cretaceous deposits. Some of the water recharged on the Eastern Shore flows eastward toward the Atlantic Ocean; some flows westward toward the Chesapeake Bay. On both sides of the Bay, ground water following the shortest flowpaths flows from upland areas and discharges into adjacent marshes, streams, and estuaries. Following intermediate flowpaths, ground water recharged on the eastern and western shores flows laterally and discharges upward into the Chesapeake Bay. The longest flowpath is followed by ground water that infiltrates on the western shore and flows downdip beneath the Chesapeake Bay toward the Atlantic Ocean.

\section{Geology}

J-Field is located within the Coastal Plain physiographic province of Maryland, which is underlain by gently dipping, unconsolidated sedimentary rocks. Metamorphic rocks similar to those that crop out at the Fall Line in the Piedmont physiographic province underlie the Coastal Plain sediments. Estimates of the depth to bedrock in the study area range from $350 \mathrm{ft}$ (Owens, 1969) to $800 \mathrm{ft}$ (Otton and Mandle, 1984) below sea level. The Coastal Plain sediments that overlie the metamorphic basement consist of the Patapsco Formation of the Potomac Group of Cretaceous age, an interbedded sand and clay unit of fluvial origin, and the Talbot Formation of Pleistocene age, a complex of fluvial, estuarine, and marginal marine deposits composed of sand, gravel, and silty clay (Owens, 1969).

\section{Cretaceous Deposits}

The Cretaceous deposits in the study area consist of interbedded, fine- grained quartz sand and massive clay. Geologic sections that define the hydrogeologic framework at J-Field are shown in figures 8,9 , and 10 . In the western part of the study area, the top of the Cretaceous deposits is found at a depth of approximately $110 \mathrm{ft}$ below land surface (fig. 9). In the eastern part of the study area, the deposits are significantly deeper, almost $160 \mathrm{ft}$ below land surface (fig. 10). This configuration of the upper surface of the Cretaceous deposits was formed by erosion during a lower stand of sea level in the Pleistocene epoch. The depth of erosion of the Cretaceous deposits, and the presence of Pleistocene fluvial sediments overlying the Cretaceous deposits, indicates that a major stream channel, such as the ancestral Susquehanna River channel, was located beneath the present-day study area. Pleistocene erosional channels in Cretaceous and Tertiary sediments are a common feature of the Chesapeake Bay region (Kerhin and others, 1988).

The Cretaceous sediments in the study area belong to the Patapsco Formation of the Potomac Group. In the Baltimore type area, this unit is further divided into the Patuxent Formation, Arundel Clay, and Patapsco Formation, all of early Cretaceous age (Owens, 1969). The Cretaceous deposits that were encountered in boreholes at J-Field are most likely part of the Patapsco Formation. A pollen sample taken from the Cretaceous deposits at nearby Graces Quarters (fig. 1) contained an early Cretaceous pollen assemblage (G.S. Brush, Johns Hopkins University, written commun., 1989). The presence of angiosperm pollen in the sample 


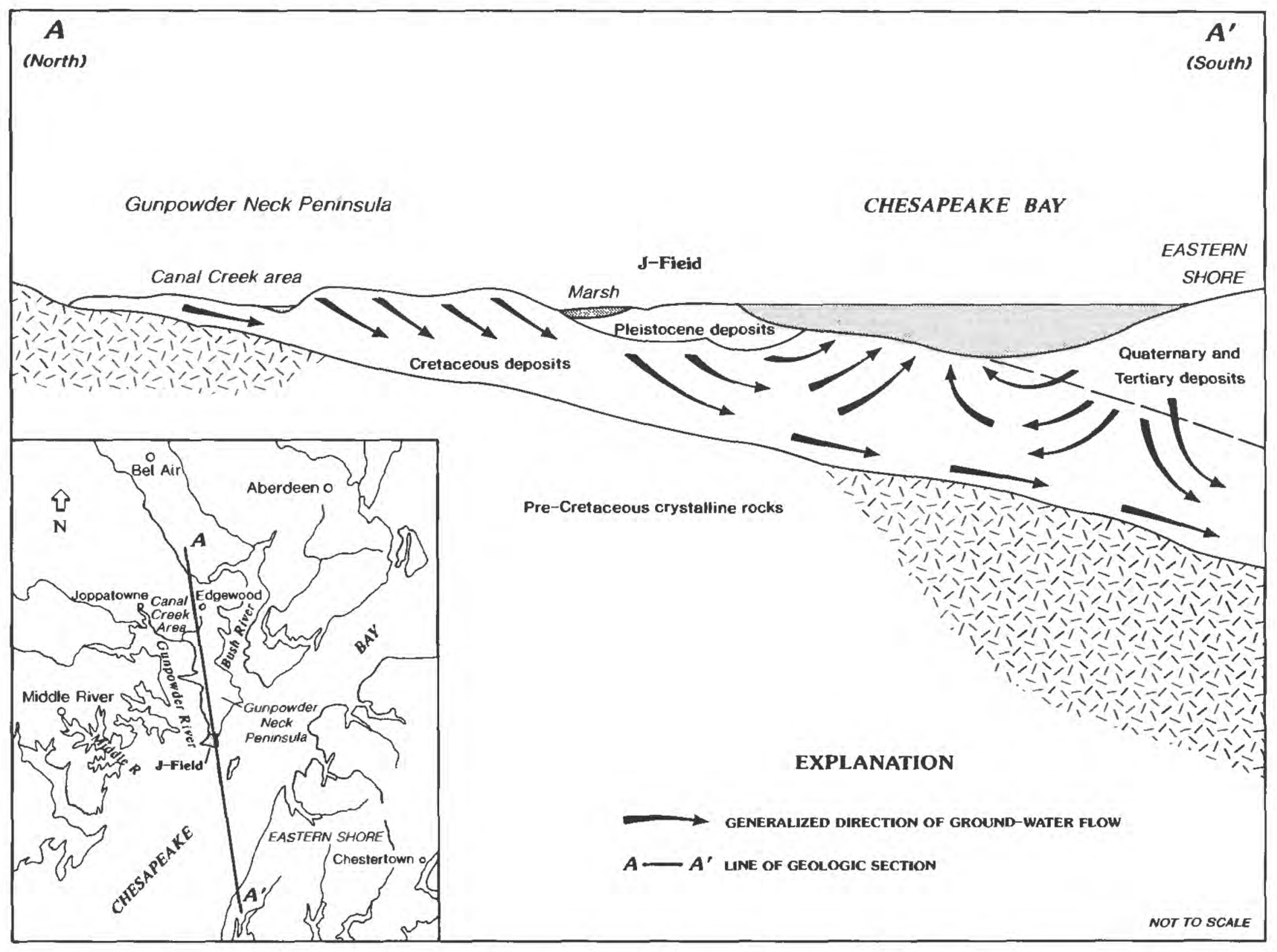

Figure 7.--Geologic units and generalized directions of ground-water flow in the upper Chesapeake Bay area. 


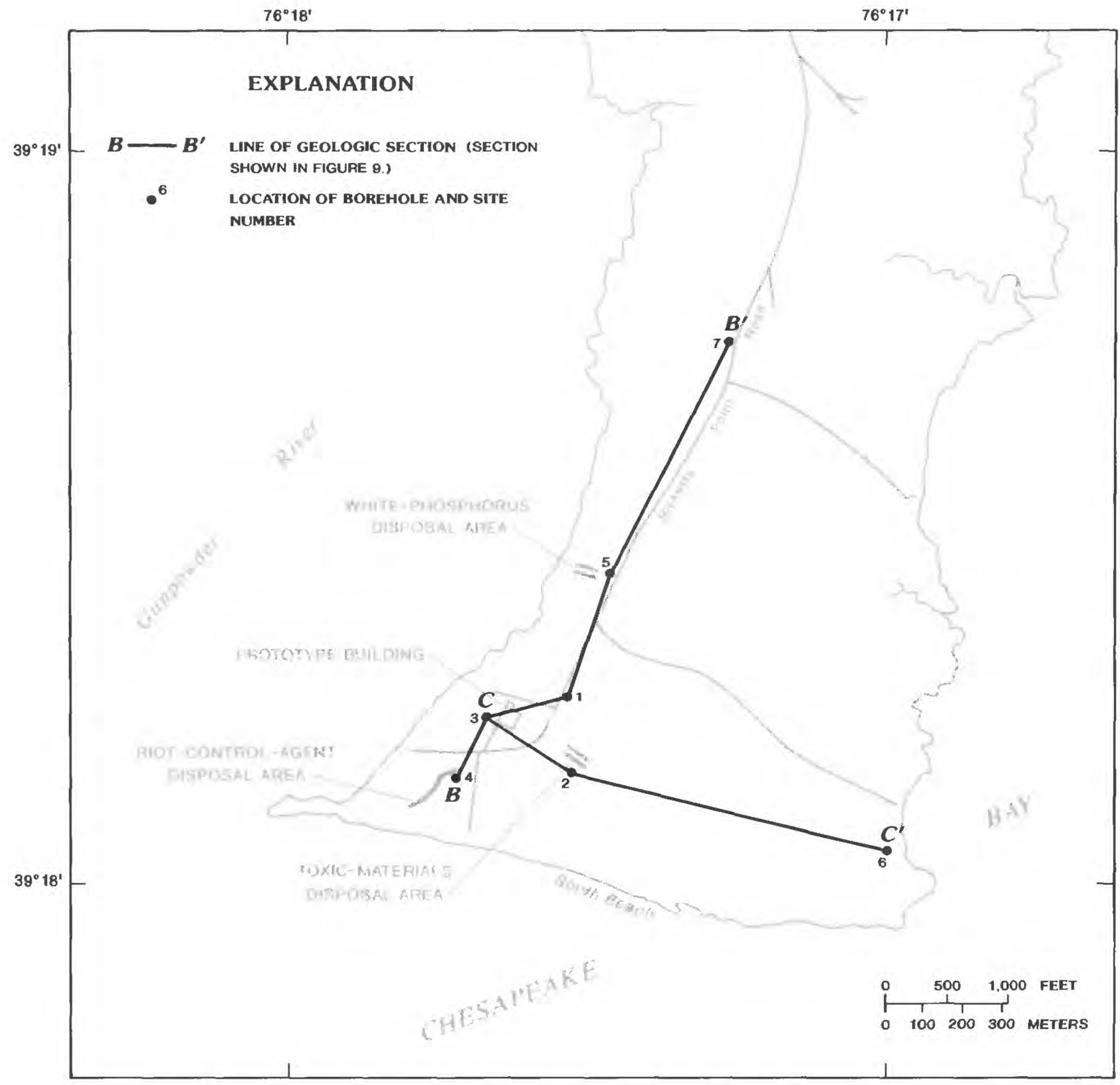

Figure 8.--Location of geologic sections. 


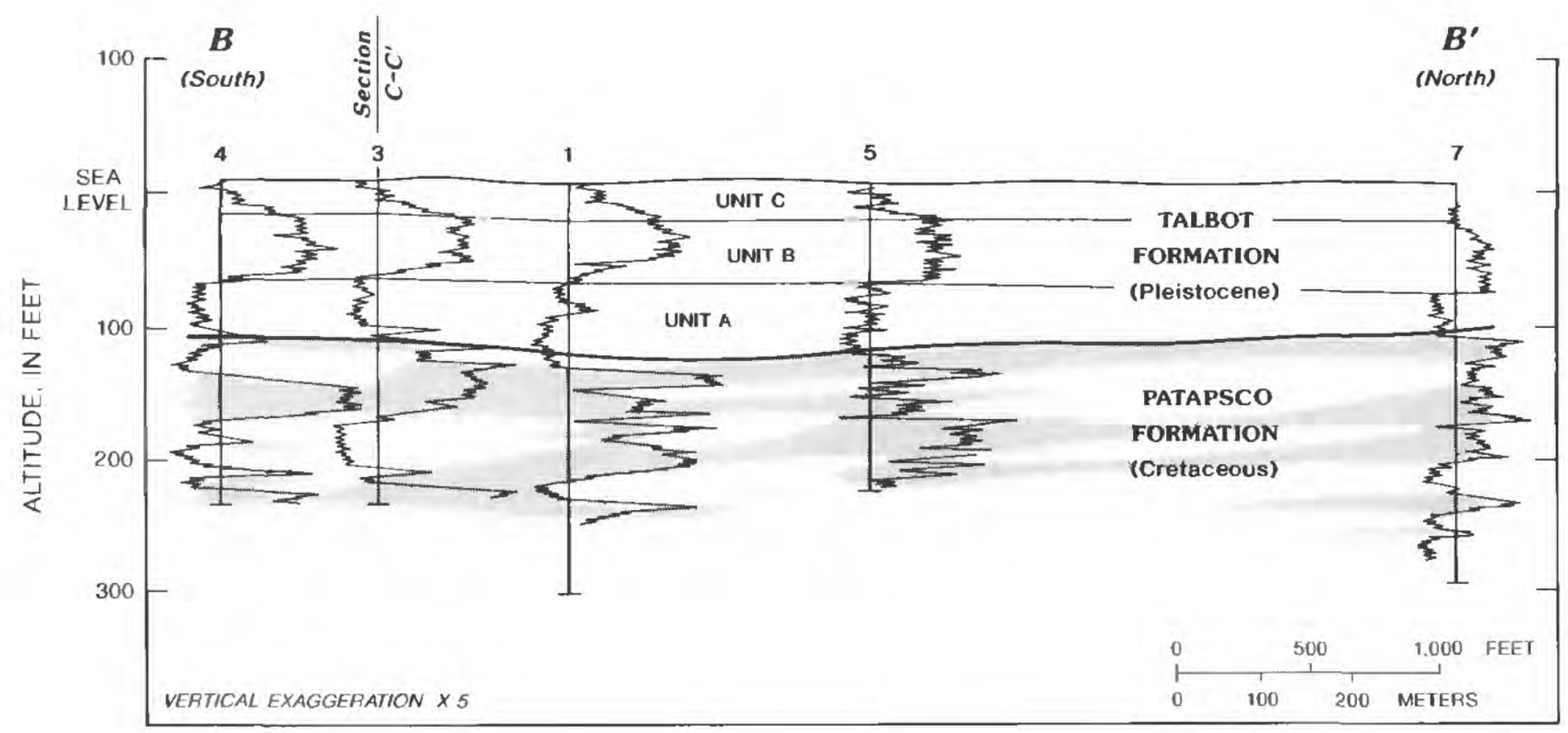

Figure 9.--Geologic section B-B'.

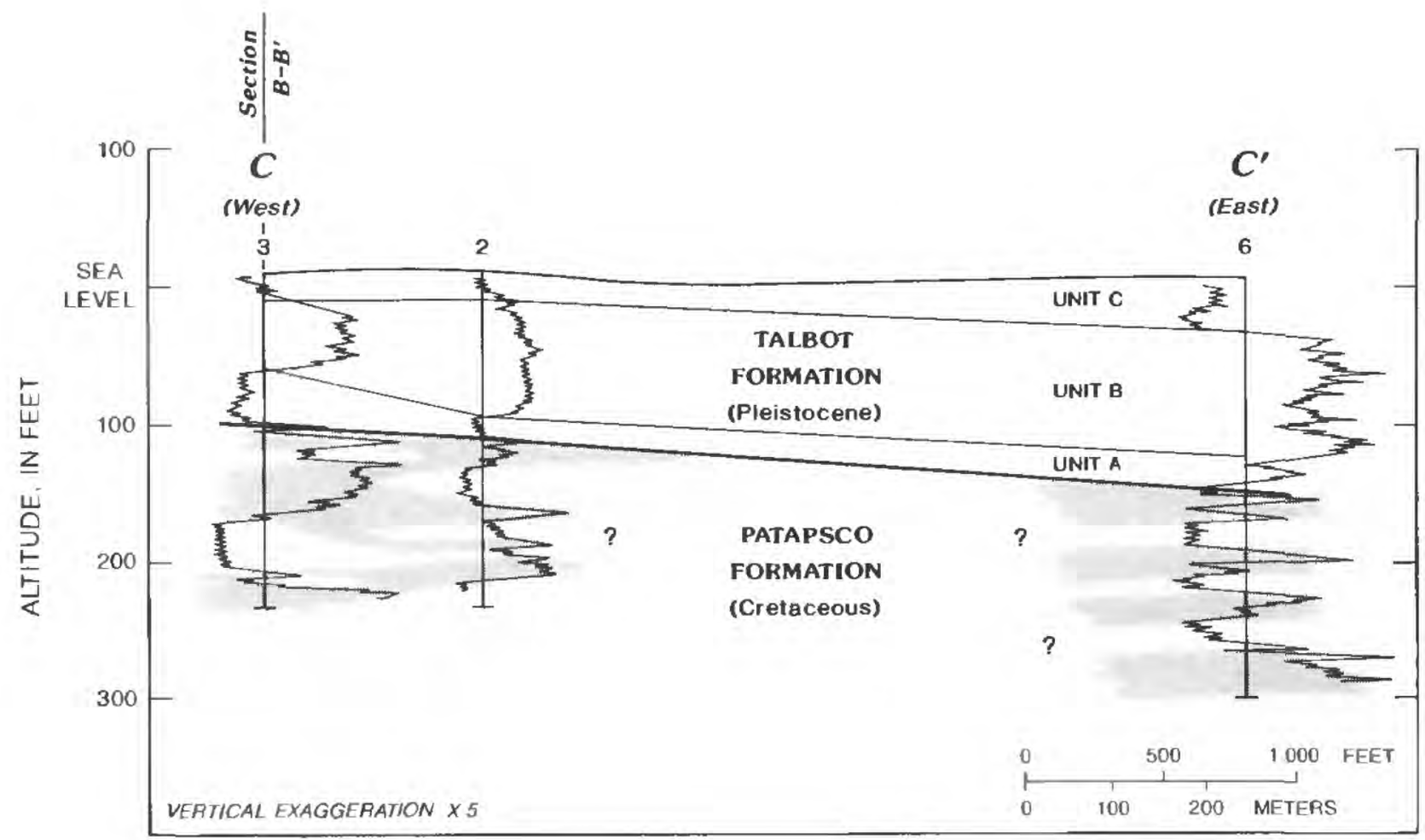

EXPLANATION

(for Sections B-B' and C-C')

EXPLORATORY BOREHOLE

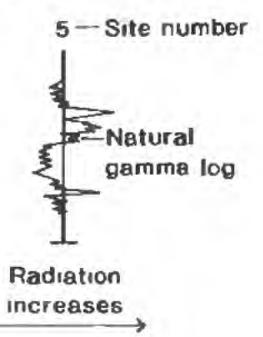

\section{TALBOT FORMATION \\ (Columbia Group)}

UNIT C - Interbedded sand and clay

UNIT B - Silty clay

UNIT A - Send and gravel

LITHOLOGIC CONTACT
PATAPSCO FORMATION

(Potomac Group)

Sand

Clay

Figure 10.--Geologic section C-C'. 
indicates that the sample came from the Patapsco Formation (Brenner, 1963). The general stratigraphic sequence described by Owens (1969) for the Potomac Group in outcrop areas is that of gravel at the base, clay in the middle, and interbedded sand and clay at the top.

Interpretations of natural gamma logs of the Patapsco Formation indicate that the thickness of the sand beds range from 2 to $30 \mathrm{ft}$ and the thickness of the clay beds range from 5 to $45 \mathrm{ft}$ (figs. 9 and 10). Split-spoon samples from the sand beds contained fine-grained, rounded, quartz sand, with colors that ranged from white to brownishgray. The clay beds are strongly colored and some are mottled. The colors include reddishbrown, olive-brown, red, and dark brown. Fine laminations are present in some of the clay beds. Lithologic logs of the exploratory boreholes and observation wells are listed in table 8 at the end of the report.

The sediments that make up the Potomac Group were deposited in a complex river system consisting of channels, flood plains, and cutoffmeander swamps (Minard and others, 1980). At J-Field, the individual beds within the Patapsco Formation are, for the most part, laterally discontinuous and variable in thickness (figs. 9 and 10). The discontinuous nature of the individual beds is typical of alluvial sediments. Owens (1969) gave the following evidence for an alluvial origin of the lower Cretaceous deposits in Harford County: (1) extensive cross-stratification, (2) erratic distribution of lithofacies, (3) presence of channel-fill sediments, and (4) wide range in bed thickness.

Two samples collected from cores in the Patapsco Formation were analyzed for mineralogy (table 2), major elements (table 3), and trace elements (table 4). A sample collected from exploratory borehole B4 at a depth of $161 \mathrm{ft}$ consisted of mottled red and brown clay. A sample collected from the same borehole at a depth of $241 \mathrm{ft}$ was composed of silty and sandy clay. The mineralogy of the two samples from the Patapsco Formation was dominated by quartz (table 2). The next most common minerals for the sample collected at a depth of
$161 \mathrm{ft}$ were kaolinite and illite; those for the sample from a depth of $241 \mathrm{ft}$ were pyrite and marcasite. Hematite and goethite are present in the sample from a depth of $161 \mathrm{ft}$ and could be an oxidized equivalent of the pyrite and marcasite in the sample from a depth of $241 \mathrm{ft}$. The conditions that prevailed during and since deposition control the oxidation state of the minerals in the sediments.

The most common major elements in the core samples from the Patapsco Formation are aluminum, iron, and potassium (table 3 ). The sample from a depth of $161 \mathrm{ft}$ contains higher concentrations of aluminum and potassium than do other samples because of the higher percentage of clay minerals at this interval that contain these elements. The higher concentration of iron in the sample from a depth of $241 \mathrm{ft}$ resulted from the greater concentration of iron-bearing minerals in that sample, when compared to other samples. The elemental analysis for the sample from a depth of $241 \mathrm{ft}$ shows elevated concentrations of cobalt, nickel, and arsenic (table 4).

These elements commonly replace the iron in marcasite and pyrite, forming minerals such as arsenopyrite (FeAsS), cobaltite ((Co,Fe)AsS), and niccolite (NiAs) (Hurlbut and Klein, 1977).

\section{Pleistocene Deposits}

Paleochannel deposits of Pleistocene age consisting of gravel, sand, and clay are present in many areas of the Chesapeake Bay region (Hack, 1957; Hansen, 1966; Colman and Mixon, 1988). These deposits typically consist of fluvial sediments, such as sand and gravel, overlain by much finer grained silty sand and clay of estuarine origin. The deposits are found in channels that were eroded during low stands of sea level that resulted from the accumulation of glacial ice on land areas. Fluvial and estuarine sediments were deposited in the channels during periods of rising sea level in interglacial periods. The Chesapeake Bay is an example of this cycle of erosion and sedimentation. The valley that forms the Chesapeake Bay was eroded during the Wisconsin glaciation and subsequently flooded during the Holocene (Kerhin and others, 1988). 
Table 2.--Relative percentages of minerals in core samples

[Values are percentages of minerals detected; depths are feet below land surface; --, not detected; <, less than; A, B, and C refer to units within the Talbot Formation; K = Patapsco Formation; ]

\begin{tabular}{|c|c|c|c|c|c|c|c|c|c|c|c|c|c|c|}
\hline $\begin{array}{l}\text { Well } \\
\text { no. }\end{array}$ & $\begin{array}{l}\text { Depth } \\
\text { (feet) }\end{array}$ & $\begin{array}{l}\text { Lithologic } \\
\text { unit }\end{array}$ & Quartz & Illite & Kaolinite & $\begin{array}{l}\text { Montmoril } \\
\text { lonite }\end{array}$ & Plagioclase & Feldspar & Hematite & Geothite & Gypsum & Pyrite & Aragonite & Marcasite \\
\hline JF41 & 1 & C & 98 & $<1$ & - & - & 1 & - & - & - & - & - & - & - \\
\hline JF41 & 3 & C & 85 & 2 & 2 & 1 & 5 & 3 & - & - & - & - & - & - \\
\hline JF91 & 4 & C & 92 & 2 & - & - & 3 & 3 & - & - & - & - & - & - \\
\hline JF91 & 11 & C & 95 & $<1$ & $<1$ & - & 2 & - & - & - & - & - & - & - \\
\hline JF41 & 18 & c & 85 & 4 & 4 & -- & 5 & 2 & - & - & - & - & - & - \\
\hline JF91 & 45 & B & 60 & 4 & 4 & - & 4 & - & - & - & 1 & 6 & 20 & - \\
\hline JF41 & 55 & B & 65 & 8 & 10 & 2 & 6 & 3 & - & - & - & 6 & - & - \\
\hline JF41 & 78 & A & 93 & 1 & 1 & $<1$ & 2 & - & - & - & - & 2 & - & - \\
\hline B4 & 102 & A & 95 & $<1$ & $<1$ & - & 2 & 1 & - & - & - & - & - & - \\
\hline B4 & 161 & $\mathbf{K}$ & 70 & 8 & 10 & - & $<1$ & - & 7 & 4 & - & - & - & - \\
\hline B4 & 241 & $\mathbf{K}$ & 65 & $<1$ & 1 & -. & - & - & - & - & - & 20 & - & 12 \\
\hline
\end{tabular}

\section{Table 3.--Percentage of major elements present in core samples}

IValues are reported as percentage of total sample; depths are feet below land surface; $A, B$, and C refer to units within the Talbot Formation; $\mathrm{Al}=$ aluminum; $\mathrm{K}=$ Patapsco Formation; $\mathrm{Ca}=$ calcium; $\mathrm{Fe}=$ iron; $\mathrm{K}=$ potassium; $\mathrm{Mg}=$ magnesium; $\mathrm{Na}$ = sodium; $\mathrm{P}=$ phosphorus; $\mathrm{Ti}=$ titanium $]$

\begin{tabular}{|c|c|c|c|c|c|c|c|c|c|c|}
\hline $\begin{array}{l}\text { Well } \\
\text { no. }\end{array}$ & $\begin{array}{l}\text { Depth } \\
\text { (feet) }\end{array}$ & $\begin{array}{l}\text { Lithologic } \\
\text { unit }\end{array}$ & $\mathrm{Al}$ & $\mathrm{Ca}$ & $\mathbf{F e}$ & K & $\mathrm{Mg}$ & $\mathrm{Na}$ & $\mathbf{P}$ & $\mathrm{Ti}$ \\
\hline JF41 & 1 & C & 1.68 & 0.07 & 0.84 & 0.46 & 0.12 & 0.24 & 0.01 & 0.19 \\
\hline JF41 & 3 & C & 5.27 & .19 & 2.55 & 1.29 & .40 & .53 & .03 & .34 \\
\hline JF91 & 4 & $c$ & 6.61 & .08 & 1.92 & 1.46 & .34 & .27 & .01 & .30 \\
\hline JF41 & 10 & C & 2.03 & .07 & .84 & .55 & .16 & .29 & .01 & .16 \\
\hline JP91 & 11 & C & 1.51 & .07 & .57 & .44 & .13 & .26 & .01 & .18 \\
\hline JF41 & 18 & c & 5.54 & .09 & 1.96 & 1.53 & .50 & .50 & .02 & .30 \\
\hline JP91 & 45 & B & 5.57 & 6.38 & 4.25 & 1.62 & .56 & .48 & .04 & .26 \\
\hline JF41 & 55 & B & 6.53 & .57 & 4.07 & 1.90 & .66 & .49 & .04 & .35 \\
\hline JF41 & 78 & A & 2.46 & .17 & 2.01 & .75 & .26 & .25 & .01 & .19 \\
\hline JF91 & 88 & A & 2.75 & .28 & 1.33 & .82 & .25 & .27 & .01 & .18 \\
\hline B4 & 102 & A & 1.39 & .10 & 1.08 & .43 & .14 & .29 & .01 & .08 \\
\hline B4 & 161 & K & 8.39 & .06 & 6.64 & 1.63 & .25 & .09 & .07 & .37 \\
\hline B4 & 241 & K & 3.51 & .07 & 12.40 & .72 & .14 & .09 & .01 & .21 \\
\hline
\end{tabular}




\section{Table 4.--Concentrations of trace elements in core sample}

[Concentrations are in parts per million; depths are feet below land surface; $<$, less than; $\mathrm{A}, \mathrm{B}$, and $\mathrm{C}$ refer to units within the Talbot Formation; $\mathrm{K}=$ Patapsco Formation; $\mathrm{As}=$ arsenic; $\mathrm{Ba}=$ barium; $\mathrm{Be}=$ beryllium; $\mathrm{Ce}=$ cerium; $\mathrm{Co}=\mathrm{cobalt} ; \mathrm{Cr}=$ chromium; $\mathrm{Cu}=$ copper; $\mathrm{Ga}=$ gallium; $\mathrm{La}=$ lanthanum; $\mathrm{Li}=$ lithium; $\mathrm{Mn}=$ manganese; $\mathrm{Mo}=$ molybdenum; $\mathrm{Nb}=$ niobium; $\mathrm{Nd}=$ neodymium; $\mathrm{Ni}=$ nickle; $\mathrm{Pb}=$ lead; $\mathrm{Sc}=$ scandium; $\mathrm{Sr}=$ strontium; $\mathrm{Th}=$ thorium; $\mathrm{V}=$ vanadium; $\mathrm{Y}=\mathrm{yttrium} ; \mathrm{Yb}=$ ytterbium; $\mathrm{Zn}=$ zinc]

\begin{tabular}{|c|c|c|c|c|c|c|c|c|c|c|c|c|c|c|c|c|c|c|c|c|c|c|c|c|c|}
\hline $\begin{array}{l}\text { Well } \\
\text { no. }\end{array}$ & $\begin{array}{l}\text { Depth } \\
\text { (feet) }\end{array}$ & $\begin{array}{l}\text { Lithoiogic } \\
\text { unit }\end{array}$ & As & $\mathbf{B a}$ & $\mathbf{B e}$ & Ce & Co & $\mathrm{Cr}$ & $C_{\mathbf{u}}$ & $\mathrm{Ga}$ & $\mathbf{L a}$ & Li & $\mathbf{M n}$ & Mo & $\mathbf{N b}$ & Nd & $\mathbf{N i}$ & $\mathbf{P b}$ & Sc & Sr & Th & $\mathbf{V}$ & $\mathbf{Y}$ & $\mathbf{Y b}$ & $\mathrm{Zn}_{\mathrm{n}}$ \\
\hline JF4I & 1 & C & $<10$ & 108 & $<1$ & 47 & 5 & 20 & 5 & $<4$ & 21 & 19 & 66 & $<2$ & 5 & 22 & 9 & 6 & 3 & 27 & 5 & 22 & 7 & 1 & 16 \\
\hline $\mathrm{JF} 4 \mathrm{I}$ & 3 & C & $<10$ & 292 & 1 & 63 & 8 & 65 & 14 & 12 & 32 & 37 & 131 & $<2$ & 10 & 31 & 19 & 15 & 10 & 67 & 10 & 71 & 14 & 2 & 49 \\
\hline JFO1 & 4 & c & 10 & 315 & 1 & 75 & 6 & 90 & 18 & 17 & 37 & 58 & 50 & $<2$ & 9 & 34 & 16 & 18 & 13 & 59 & 13 & 93 & 15 & 2 & 46 \\
\hline JF4I & 10 & C & $<10$ & 123 & $<1$ & 45 & 5 & 24 & 7 & 5 & 20 & 25 & 65 & $<2$ & $<4$ & 18 & 10 & 6 & 3 & 31 & 4 & 23 & 7 & 1 & 26 \\
\hline JF91 & 11 & $c$ & $<10$ & 106 & $<1$ & 50 & 3 & 16 & 4 & $<4$ & 22 & 20 & 48 & $<2$ & 5 & 22 & 7 & 6 & 2 & 26 & 4 & 18 & 7 & $<1$ & 22 \\
\hline JF4l & 18 & C & $<10$ & 320 & 2 & 76 & 15 & 70 & 18 & 13 & 37 & 53 & 149 & $<2$ & 9 & 37 & 30 & 15 & 10 & 62 & 10 & 77 & 20 & 3 & 83 \\
\hline JF9l & 45 & B & $<10$ & 211 & 2 & 69 & 16 & 69 & 17 & 15 & 36 & 52 & 1,070 & $<2$ & 7 & 35 & 29 & 16 & 11 & 266 & 10 & 75 & 20 & 3 & 77 \\
\hline JF41 & 55 & B & 10 & 107 & 2 & 83 & 19 & 88 & 19 & 16 & 40 & 60 & 1,030 & $<2$ & 9 & 41 & 37 & 17 & 13 & 94 & 12 & 92 & 24 & 3 & 92 \\
\hline JF41 & 78 & A & 10 & 155 & $<1$ & 35 & 12 & 40 & 9 & 6 & 15 & 25 & 466 & $<2$ & 5 & 16 & 16 & 8 & 5 & 40 & 5 & 37 & 9 & 1 & 38 \\
\hline JF91 & 88 & A & 10 & 196 & 1 & 38 & 10 & 39 & 13 & 7 & 18 & 24 & 158 & $<2$ & 5 & 16 & 15 & 10 & 5 & 45 & 4 & 44 & 9 & 1 & 53 \\
\hline B4 & 161 & $\mathbf{K}$ & 10 & 335 & 3 & 101 & 5 & 102 & 23 & 22 & 49 & 21 & 63 & $<2$ & 11 & 47 & 12 & 17 & 22 & 72 & 14 & 227 & 21 & 3 & 23 \\
\hline B4 & 241 & $\mathbf{K}$ & 480 & 19 & 1 & 42 & 311 & 50 & 28 & 9 & 19 & 18 & 64 & 7 & 7 & 20 & 774 & 46 & 7 & 35 & 8 & 63 & 12 & 2 & 4 \\
\hline
\end{tabular}

The Talbot Formation comprises the Pleistocene deposits in the study area. The Talbot Formation is a complex sequence of paleochannel deposits that can be divided into three lithologic units. From bottom to top, these units are basal sand and gravel (unit A), sandy and silty clay (unit B), and interbedded sand and clay (unit C) (figs. 9 and 10). The basal unit is 13 to $50 \mathrm{ft}$ thick and consists of gravelly sand within a matrix of clay and clayey sand. The gravel is well rounded and ranges in size from pebbles to small cobbles. The larger clasts are predominantly rock fragments of sandstone, granitic rock, or gneiss. In general, this unit (henceforth referred to as "unit A") is of fluvial origin, containing sediment derived from local sources in the Piedmont province or from the ancestral Susquehanna River basin. These basal deposits lie unconformably over fine sand or clay of the Patapsco Formation. The thickness of unit $A$ is about 35 to $50 \mathrm{ft}$ in the western part of the study area and thins considerably to the east, where it is only $15 \mathrm{ft}$ thick at exploratory borehole B6 (fig. 10).
Unit B lies conformably over the fluvial sediments of unit A and consists of olive-gray, silty, sandy clay. The sand is very fine grained and comprises less than 30 percent of the sample. Bivalve shells and shell fragments range from trace amounts in the upper part of the unit to as much as 70 percent of the sample in some sections near the base. Amounts of organic matter range from minor, chiefly composed of fine-grained organic particles, to abundant, where it represents 75 percent of the sample in some zones and is composed of leaves, stems, and large woody fragments. The fine-grained nature of the sediments and the abundance of bivalve shells indicate that unit $B$ is estuarine in origin.

Unit B is 50 to $107 \mathrm{ft}$ thick at the boreholes (figs. 9 and 10) but is as thin as $36 \mathrm{ft}$ in well cluster JF2 (table 8). The upper surface of unit B is fairly uniform, and its lower surface conforms to the top of unit A. As a result, unit B is thickest where the depth of erosion in the Patapsco Formation in greatest. 
Unit C consists primarily of a nonhomogeneous mixture of medium- to fine-grained sand and interbedded clay. The sand and clay beds are 2 to $10 \mathrm{ft}$ thick and are laterally discontinuous (table 8). The sand is red to gray, and the clay is dark to light gray. The total thickness of this unit is generally 30 to $40 \mathrm{ft}$ (figs. 9 and 10). This unit was probably deposited in an estuarine or marginal marine environment that prevailed during a high stand of sea level.

The Pleistocene deposits consist of an interglacial channel-fill sequence of fluvial, estuarine, and marginal-marine sediments that were deposited as a result of rising sea level. The gravel and sand of unit A is of fluvial origin, as shown by its coarse-grained texture. Owens (1969) observed extensive trough cross-stratification in the sand and gravel in similar deposits in Harford County, and noted that these deposits were restricted to distinct channels. Unit B is similar to deposits in the Sparrows Point area of Baltimore described by Bennett and Meyer (1952), who suggested that an ancestral Susquehanna River channel formed in the Sparrows Point area during a past glacial stage. During the subsequent interglacial stage, the channel was flooded by a rise in sea level, which caused the deposition of estuarine sediments in the channel. The channel-like geometry, abundant fossil-shell material, organic matter, and fine-grained character of the Sparrows Point sediments support this hypothesis. The lithology of unit $C$ and its stratigraphic position above the estuarine sediments indicate that this unit was deposited in a marginal marine to marine-nearshore environment. Unit $C$ was probably deposited during the late interglacial stage, as sea level continued to rise and much of the coastal plain was inundated.

Units $\mathrm{A}$ and $\mathrm{C}$ are predominantly quartz with minor amounts of clay minerals, plagioclase, and potassium feldspar (table 2). Unit B contains higher relative quantities of clay minerals than the other units. Aragonite comprises 20 percent of a sample from unit $B$ (JF91, $45 \mathrm{ft}$ deep) because of the large amount of shell material present in the sample. Results of the major-element analyses shown in table 3 show large variations in percentages of aluminum, potassium, calcium, and iron among lithologic units A, B, C, and $\mathrm{K}$. The trace-element contents (table 4) of manganese and strontium in unit B are significantly higher than they are in the other two units.

The types of pollen present in the samples indicate that the Pleistocene sediments were deposited during an interglacial period, probably mid-to-late interglacial (G.S. Brush, Johns Hopkins University, written commun., 1989). Results of the analyses of the pollen samples collected from units A and B of the Talbot Formation are presented in table 5 . Although the data are sparse, a greater concentration of pine pollen are found in the stratigraphically higher samples than in the stratigraphically lower samples (table 5). Less hickory, and other hard wood pollen also are found in the stratigraphically higher samples than in the stratigraphically lower samples. The abundance of hardwood species in the basal part of the sediments (JF81, unit A; B3) represents a warm interglacial climate, similar to the present climate (Sirkin and others, 1977). The abundant quantities of hickory, large amount of ragweed, and the small amount of pine pollen in unit $A$ indicate the climate was dry during the deposition of this unit. The shift to a predominance of pine species and the increase in black gum and walnut pollen in the upper part of unit $\mathrm{B}$ (sample JF61) indicates that the climate became cooler and wetter over time. A similar sequence of increases in pollen and decreases in oak and hickory pollen over time was observed in Pleistocene lake sediments in North Carolina by Whitehead (1967). Whitehead assigned the pinedominated zone to the Wisconsin stage and suggested that the oak and hickory zone represented the warm climate during the Sangamon interglacial.

Marine-seismic profiling was used in combination with the onshore borehole drilling to define the extent and geometry of the Pleistocene deposits adjacent to the study area (figs. 11 and 12). The channel-like geometry of the Pleistocene deposits can be seen in geologic section C-C' (fig. 12). Because a similar sequence 
Table 5.--Results of pollen analyses

$[-$, not detected $]$

\begin{tabular}{|c|c|c|c|c|}
\hline \multirow[b]{4}{*}{ Pollen type } & \multicolumn{2}{|c|}{ Stratigraphically } & \multirow{2}{*}{\multicolumn{2}{|c|}{ Stratigraphically }} \\
\hline & higher & & & \\
\hline & \multicolumn{4}{|c|}{ Percentage of pollen type } \\
\hline & $\begin{array}{l}\text { JF61 } \\
\text { (Unit B) }\end{array}$ & $\begin{array}{l}\text { JF81 } \\
\text { (Unit B) }\end{array}$ & $\begin{array}{l}\text { B3 } \\
\text { (Unit B) }\end{array}$ & $\begin{array}{c}\text { JF81 } \\
\text { (Unit A) }\end{array}$ \\
\hline Acer (maple) & 1.8 & 2.5 & 1.4 & 5.3 \\
\hline Alnus (alder) & - & 1.2 & - & - \\
\hline Ambrosia (ragweed) & - & - & 9.6 & 7.9 \\
\hline \multicolumn{5}{|l|}{ Amaranthaceae } \\
\hline (amaranth) & .9 & - & - & - \\
\hline Betula (birch) & 1.8 & - & 2.4 & - \\
\hline Carya (hickory) & 8.2 & 16.2 & 21.9 & 31.6 \\
\hline \multicolumn{5}{|l|}{ Cephalanthus } \\
\hline (buttonbush) & - & - & 1.4 & - \\
\hline Chenopodium (pigweed) & 1) - & 1.2 & 1.4 & - \\
\hline Comus (dogwood) & - & - & 1.4 & - \\
\hline Dryopteris (wood-ferm) & - & - & 5.5 & - \\
\hline Fagus (beech) & 2.7 & - & 4.1 & 7.9 \\
\hline Fraxinus (ash) & 9 & 1.2 & 1.4 & - \\
\hline Juglans (walnut) & 4.6 & 2.5 & 12.3 & 5.3 \\
\hline Juniperus (red cedar) & - & 2.5 & - & 1.3 \\
\hline Liquidambar (sweet gum) & n) - & - & 2.7 & 1.3 \\
\hline Lycopodium (club moss) & 1.8 & 1.2 & 2.7 & 2.6 \\
\hline Nyssa (black gum) & 11.0 & 13.7 & 2.7 & 6.6 \\
\hline Pinus (pine) & 41.3 & 22.5 & 8.2 & 7.9 \\
\hline Prunus (cherry) & 1.8 & 1.2 & - & - \\
\hline Quercus (oak) & 18.3 & 30.0 & 17.8 & 17.1 \\
\hline \multicolumn{5}{|l|}{ Sarracenia } \\
\hline (skunk cabbage) & - & - & - & 1.3 \\
\hline Selaginella (spikemoss) & - & - & 1.2 & - \\
\hline Small tricolpate grain & - & - & 2.5 & - \\
\hline Sparganium (bur reed) & - & - & - & 1.3 \\
\hline Stellaria (chickweed) & 1.8 & - & - & - \\
\hline Thalictrum (meadow rue) & e) - & 1.4 & - & - \\
\hline Tsuga (hemlock) & 9 & 1.4 & - & 2.6 \\
\hline Ulmus (elm) & .9 & 1.4 & - & - \\
\hline
\end{tabular}

of Pleistocene deposits with variations in thickness was observed in the upper part of all of the boreholes and observation wells drilled in the study area (table 8), the lateral extent of the paleochannel deposits could not be determined solely from the onshore boreholes. It was possible, however, to map the distribution and geometry of the paleochannel deposits adjacent to J-Field with the marine-seismic records (Hughes, 1991). Only the upper Pleistocene deposits could be seen on the record except at the margins of the paleochannel, where depth penetration was sufficient to record the base of the Pleistocene deposits (fig. 12). Although the seismic records could not be used to determine the total thickness of the Pleistocene deposits in offshore areas, they could be used to determine the lateral extent of these deposits (fig. 11).

The Pleistocene paleochannel in the J-Field area is about $7,000 \mathrm{ft}$ wide and has a maximum depth of approximately $180 \mathrm{ft}$ (fig. 12). The location of the southern boundary of the paleochannel is only approximate because of the poor resolution of the seismic record in that area. The paleochannel trends from northeast to southwest in the immediate area; the deepest part of the paleochannel is on the southern side.

\section{Hydrology}

A complex interplay of factors controls the surface-water and ground-water hydrology at J-Field. These include rainfall, evapotranspiration, tides, the hydrogeologic framework, and the horizontal and vertical hydraulic conductivities of hydrogeologic units. In this report, surface-water and ground-water hydrology are discussed in separate sections, although the two are interrelated. For example, ground water discharges into the marshes at J-Field, and ground-water levels rise and fall in response to tides in the estuaries.

\section{Surface Water}

J-Field is bordered on the east, west, and south by tidal estuaries and is bounded on the north by nontidal marsh (fig. 2). Extensive marshes also are located along the southern and eastern shores of J-Field. Sand beaches have formed on the southern and southeastern shores of J-Field as a result of wave action. The beaches act as dams, preventing surface water from the marsh from draining directly into the estuaries. Consequently, the water level in the marshes is generally about $2 \mathrm{ft}$ above the high-tide level in the estuaries. During storms and unusually high 


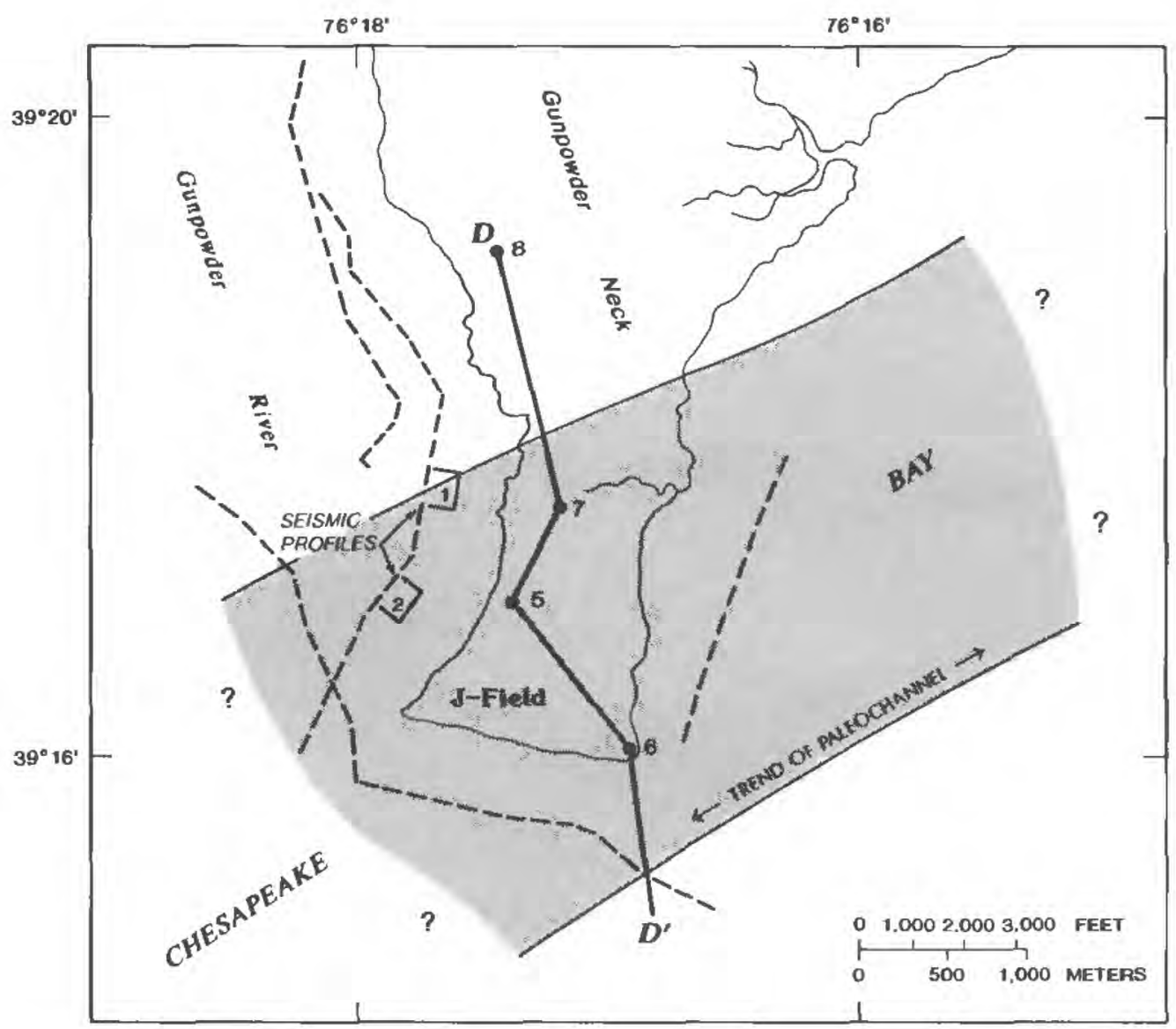

EXPLANATION

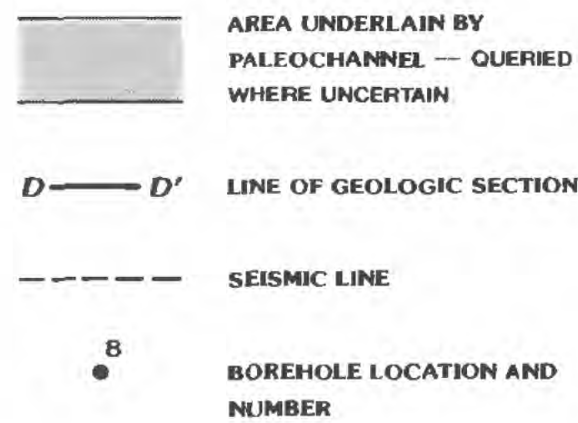

Figure 11.--Estimated extent of paleochannel deposits, locations of seismic lines, and location of geologic section D-D'.

tides, estuary water can flood the marshes, as is demonstrated by the abundant debris deposited in the marshes.

Several ponds, ranging in size from 50 to 600 $\mathrm{ft}$ in diameter are located in the marsh areas (fig. 2). When the water level in the marsh is high, the ponds are interconnected, separated only by mats of floating vegetation. The largest body of open water in the marsh is southeast of the toxicmaterials disposal area and has a maximum depth of approximately $5 \mathrm{ft}$. Two stream channels drain the eastern side of J-Field. The lower reaches of the streams are flooded by tides. The upper reaches, which are above the high-tide mark, do not contain flowing water except during storms.

The disposal pits at J-Field were originally designed so that precipitation that collected in them drained into the adjacent marsh or estuary. During the 1970's, drainage from the pits at the toxic-materials and white-phosphorus disposal areas was blocked, resulting in standing water 1 to $2 \mathrm{ft}$ deep in the pits during periods of greatest rainfall, generally from March through June. Water that collects in the pit at the riot-controlagent disposal area drains into the Gunpowder River.

\section{Ground Water}

Recharge to the ground-water-flow system at J-Field originates as precipitation. Infiltrating precipitation percolates downward through the unsaturated zone to the water table, which is located in the surficial aquifer (unit C, Talbot Formation) (fig. 13). Most of the water in the surficial aquifer flows laterally toward discharge areas in the adjacent marshes and estuaries. A small fraction of the water in the surficial aquifer percolates slowly downward through a confining unit (unit B, Talbot Formation) and eventually discharges into a confined aquifer (unit A, Talbot Formation). Lateral groundwater flow in the confining unit and the confined aquifer is slow and toward the adjacent estuaries. Ground-water flow in the Patapsco Formation is dominated by the regional flow system. In this flow system, ground water that was recharged on the eastern shore of the Chesapeake Bay 


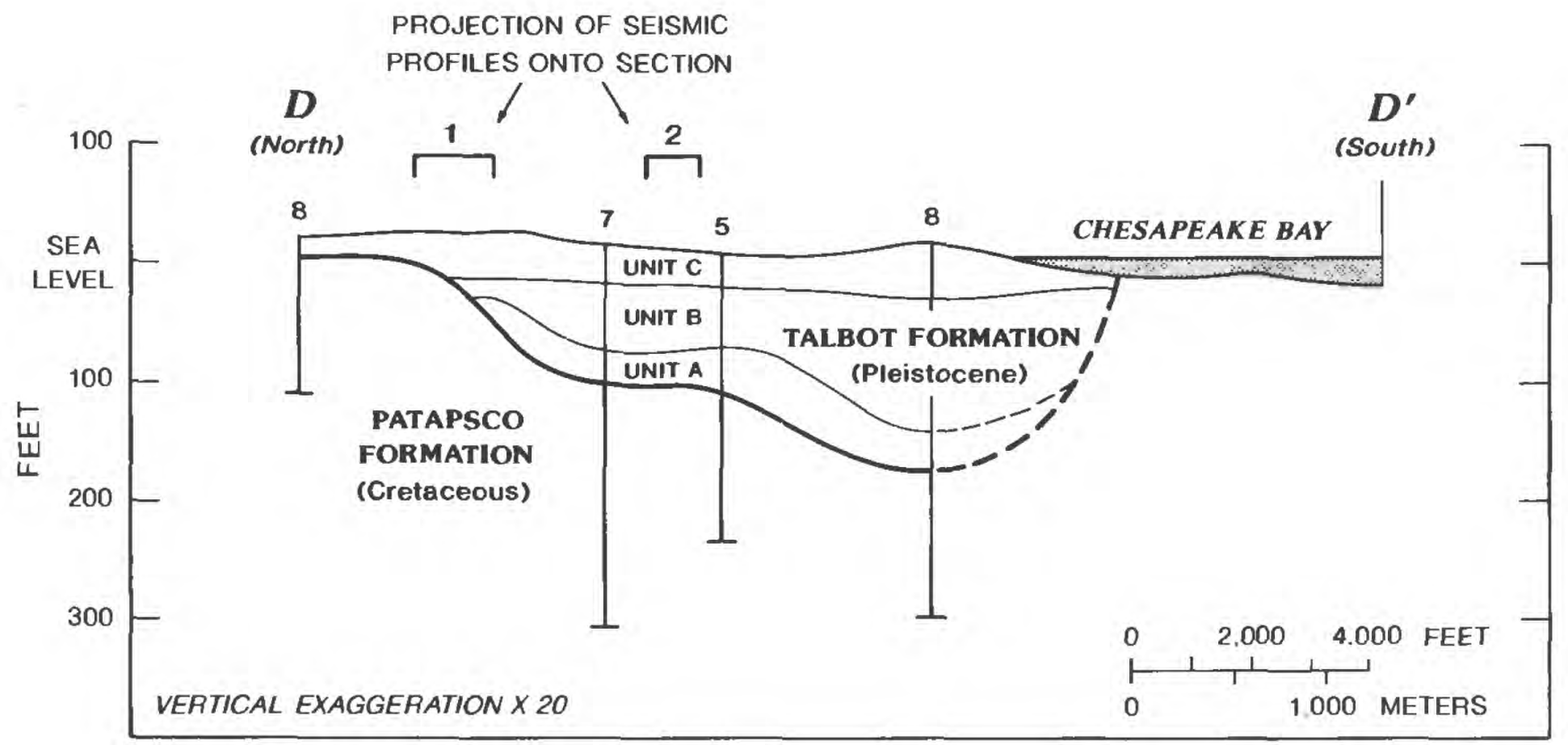

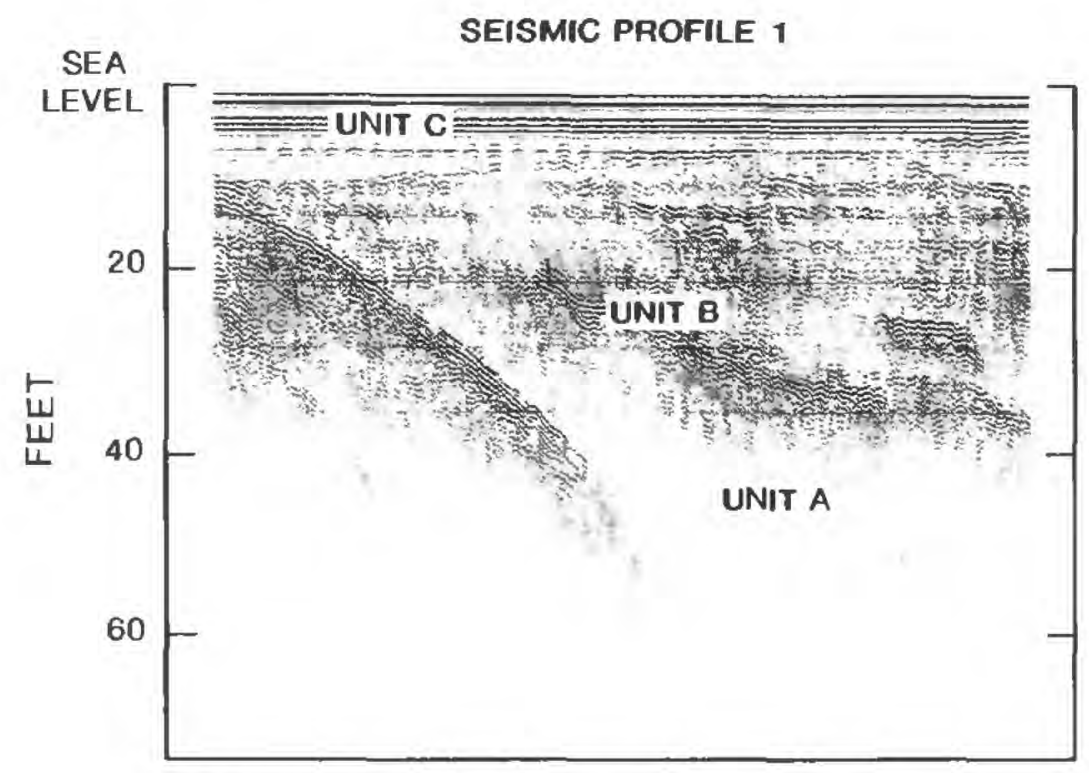

VERTICAL EXAGGERATION $\times 12$

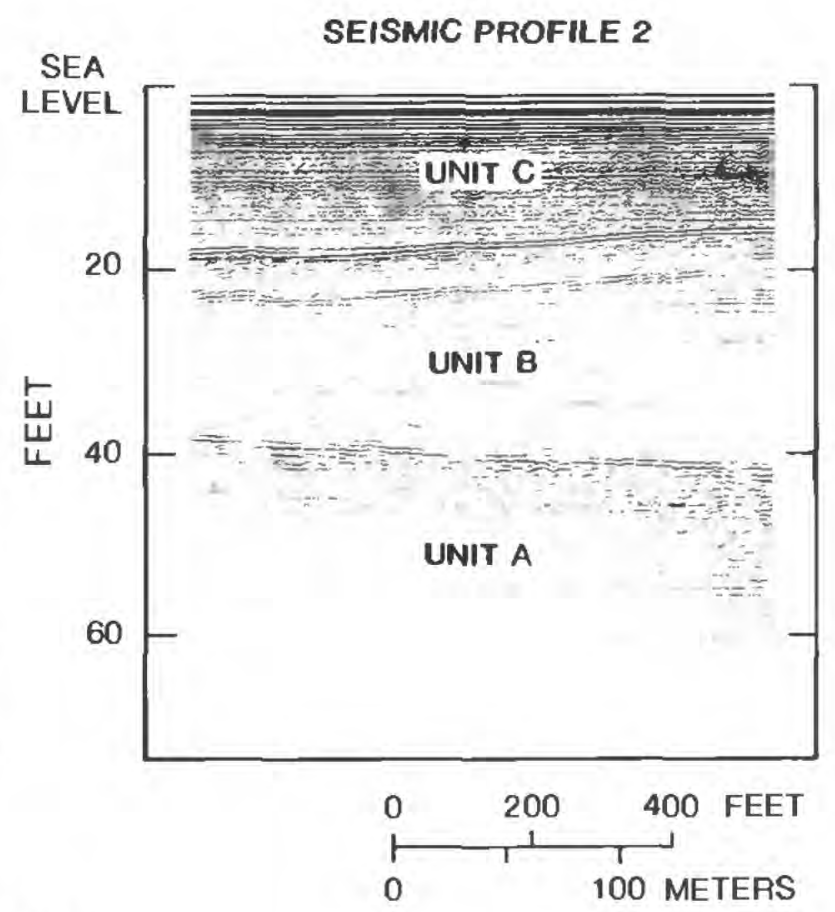

EXPLANATION

TALBOT FORMATION (Columbia Group)

UNIT c - Interbedded sand and clay

UNIT B - Silty clay

UNIT A - Sand and gravel

\section{PATAPSCO FORMATION}

(Potomac Group)

Interbedded fine sand and clay

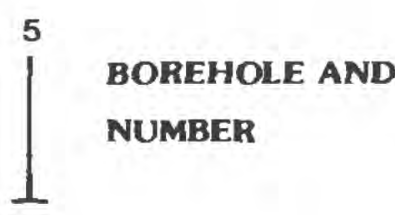

LITHOLOGIC CONTACT -- DASHED WHERE INFERRED

Figure 12.--Section D-D' and equivalent seismic profiles from the Gunpowder River. 


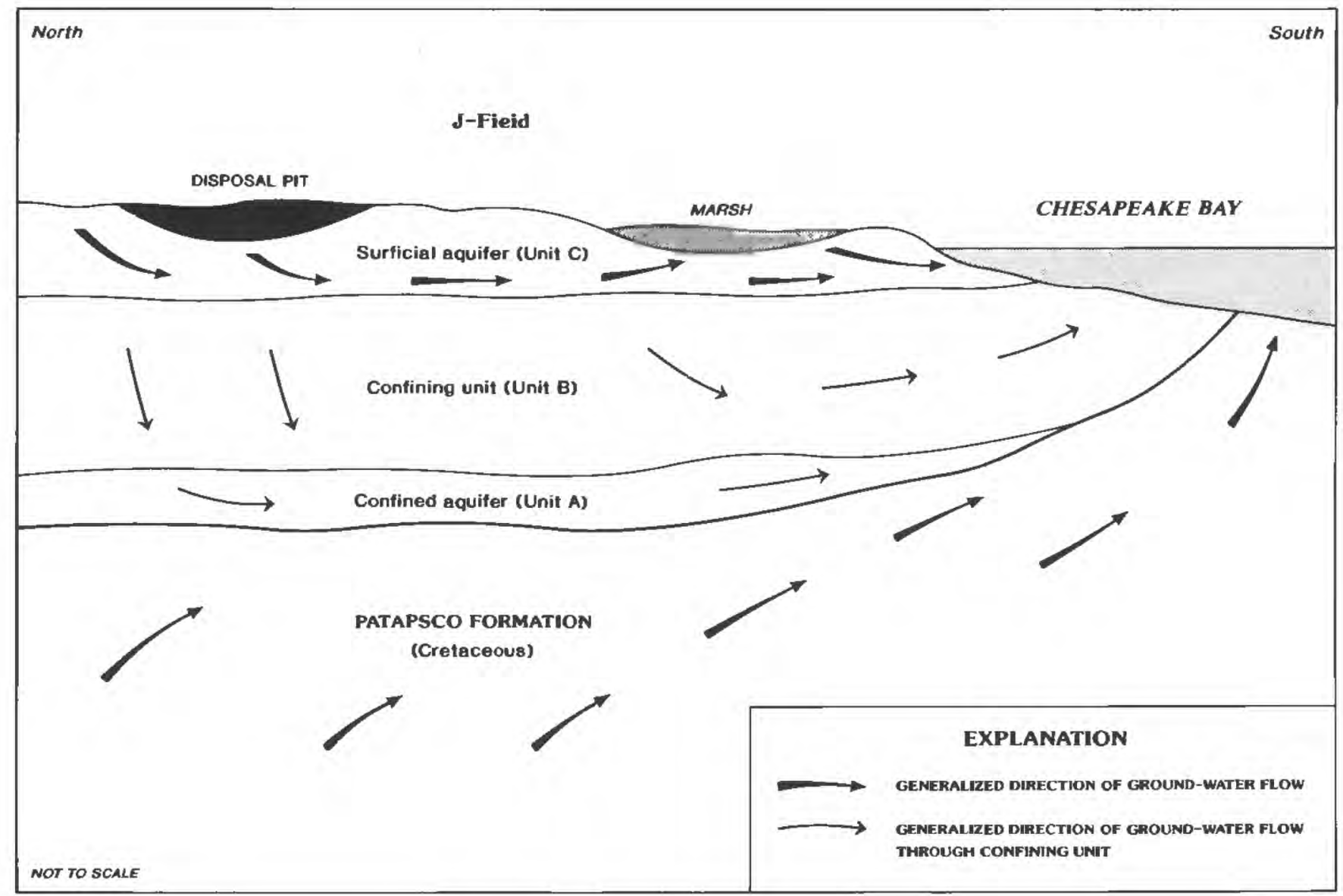

Figure 13.--Hydrogeologic units and generalized direction of ground-water flow at J-Field.

flows laterally through the Cretaceous deposits and eventually discharges into the Bay.

\section{Observation well network}

A total of 38 observation wells were installed for this investigation (fig. 14). Hydrogeologic data collected from the wells were used to characterize the aquifer and confining unit and the directions of groundwater flow. The wells also were used to collect ground-water samples that will be used to characterize the water quality in the aquifers and confining units beneath J-Field. The locations for the wells were selected on the basis of previous investigations conducted at J-Field, groundwater-flow directions (as determined by waterlevel measurements from existing wells), topography, and the results of the soil-gas sampling. Screen depths were chosen on the basis of data collected during exploratory borehole drilling. Twelve wells were screened in each of the three units of the Talbot Formation, and two wells were screened in the Patapsco Formation. Well-construction data are provided in table 6.
Wells were located in areas upgradient of the SWMU's to analyze background water quality, and downgradient of the SWMU's to determine the presence, extent, and type of ground-water contamination. Two wells were constructed in exploratory boreholes 6 and 7 (fig. 8) to analyze the water quality in the confined aquifers in the Patapsco Formation. The remaining wells were installed in the Talbot Formation. At the white-phosphorus disposal area, one well cluster was installed upgradient and three clusters downgradient (fig. 14); at the toxic-materials disposal area, one well cluster was installed upgradient and four downgradient; at the riot-control-agent disposal area, one well cluster was installed upgradient and one downgradient; and at the prototype building, a single well cluster was installed downgradient.

\section{Hydrogeologic units and hydraulic characteristics}

Four major hydrogeologic units were identified beneath J-Field. From the surface 


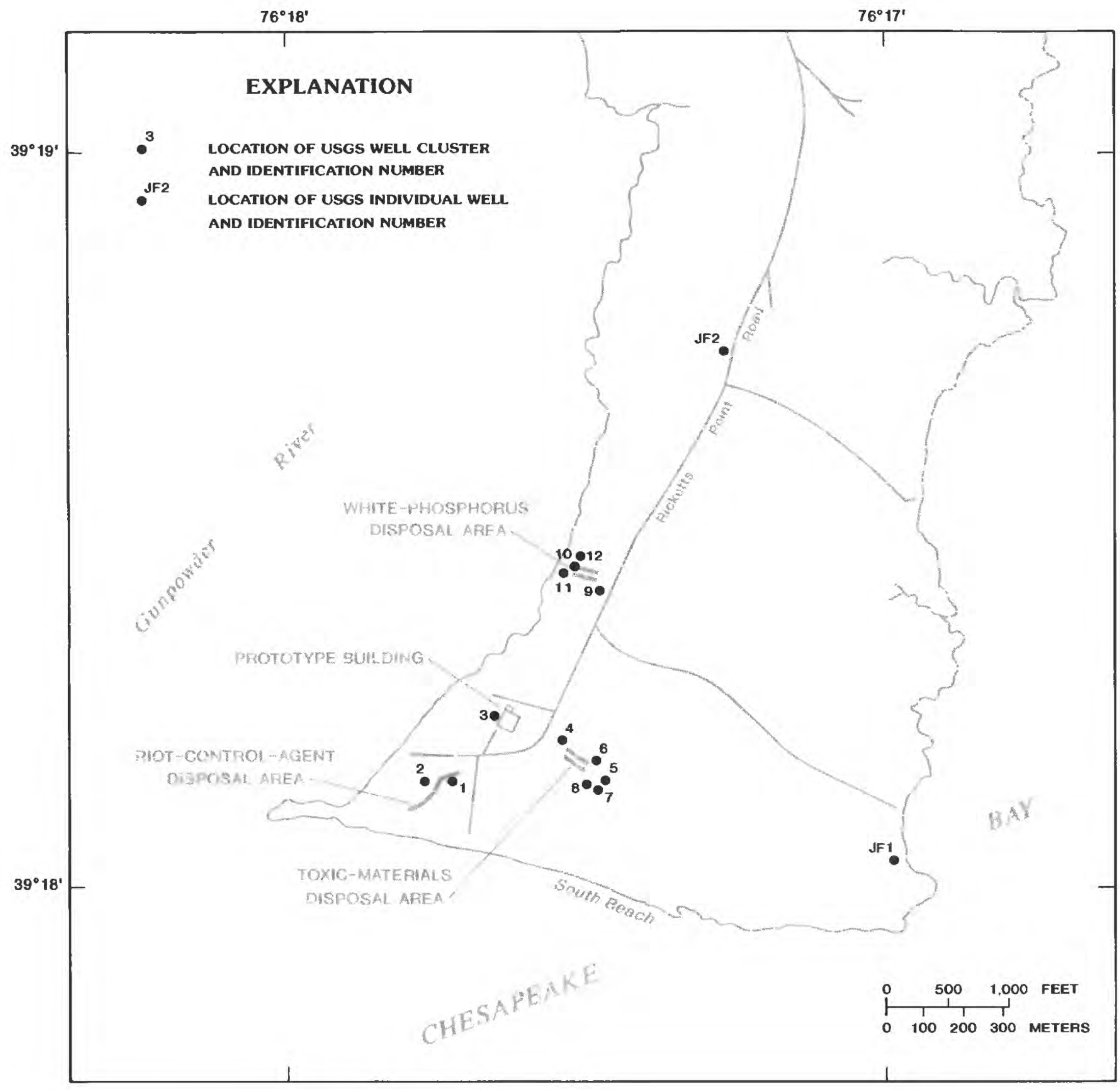

Figure 14.--Location of U.S. Geological Survey well clusters and individual well sites. 
Table 6. -Well-construction data for observation wells installed at J-Field

[U.S.Geological Survey (USGS) site identification number = latitude and longitude plus a 2-digit sequence number; --, data not available; ft A.S.L. = feet above sea level; ft B.L.S. = feet below land surface; HSA = well installed using hollow-stem auger; $M R=$ well installed using mud rotary; $C=$ surficial aquifer; $B=$ confining unit; $A=$ confined aquifer; $K=$ aquifers in Patapsco Formation]

\begin{tabular}{|c|c|c|c|c|c|c|c|c|}
\hline $\begin{array}{l}\text { Local } \\
\text { number }\end{array}$ & $\begin{array}{l}\text { USGS site } \\
\text { identification } \\
\text { number }\end{array}$ & $\begin{array}{l}\text { Maryland } \\
\text { permit number }\end{array}$ & $\begin{array}{l}\text { Altitude } \\
\text { land surface } \\
\text { (ft A.S.L.) }\end{array}$ & $\begin{array}{l}\text { Drilling } \\
\text { method }\end{array}$ & $\begin{array}{l}\text { Depth of } \\
\text { boring } \\
\text { (ft) }\end{array}$ & $\begin{array}{l}\text { Scree } \\
\text { inter } \\
\text { (ft B. }\end{array}$ & $\begin{array}{l}\text { ened } \\
\text { rval } \\
\text { L.S.) }\end{array}$ & $\begin{array}{l}\text { Unit } \\
\text { screened }\end{array}$ \\
\hline JFI & 391806076165301 & HA-88-1036 & 4.95 & MR & 190 & 185 & -190 & $\mathbf{K}$ \\
\hline JF2 & 391845076171401 & HA-88-1035 & - & MR & 300 & 208 & -213 & $\mathbf{K}$ \\
\hline JFL1 & 391809076174301 & HA-88-1037 & 7.42 & HSA & 90 & 85 & -90 & $\mathbf{A}$ \\
\hline JF12 & 391809076174302 & HA-88-1038 & 7.30 & HSA & 55 & 50 & -55 & B \\
\hline JF13 & 391809076174303 & HA-88-1039 & 7.18 & HSA & 25.5 & 20.5 & -25.5 & C \\
\hline JF21 & 391809076174601 & HA-88-1040 & 2.99 & HSA & 71 & 68 & -71 & A \\
\hline JF22 & 391809076174602 & HA-B8-1041 & 2.99 & HSA & 52.5 & 47.5 & -52.5 & B \\
\hline JF23 & 391809076174603 & HA-B8-1042 & 3.10 & HSA & 19 & 16 & -19 & C \\
\hline JF31 & 391814076173801 & HA-88-1043 & 7.67 & HSA & 81.3 & 73.8 & -78.8 & $\mathbf{A}$ \\
\hline JF32 & 391814076173802 & HA-88-1044 & 7.70 & HSA & 54.4 & 49.4 & -54.4 & B \\
\hline JF33 & 391814076173803 & HA-88-1045 & 7.79 & HSA & 20 & 15 & -20 & C \\
\hline JF41 & 391812076173101 & HA-88-1046 & 10.22 & HSA & 90 & 85 & -90 & A \\
\hline JF42 & 391812076173102 & HA-B8-1047 & 10.30 & HSA & 62 & 57 & -62 & B \\
\hline JF43 & 391812076173103 & HA-88-1048 & 10.63 & HSA & 35 & 30 & -35 & c \\
\hline JF51 & 391808076172701 & HA-88-1050 & 5.02 & HSA & 115 & 110 & -115 & A \\
\hline IF52 & 391808076172702 & HA-88-1049 & 5.27 & HSA & 65 & 60 & -65 & B \\
\hline IF53 & 391808076172703 & $\mathrm{HA}-88-1051$ & 5.10 & HSA & 19.2 & 14.2 & -19.2 & C \\
\hline JF61 & 391810076172801 & HA-88-1052 & 4.29 & HSA & 100 & 95 & -100 & $\mathbf{A}$ \\
\hline JF62 & 391810076172802 & HA-88-1053 & 4.08 & HSA & 65 & 60 & -65 & B \\
\hline JF63 & 391810076172803 & HA-88-1054 & 4.10 & HSA & 19 & 16 & -19 & C \\
\hline JF71 & 391807076172801 & HA-88-1055 & 7.26 & HSA & 125 & 120 & -125 & A \\
\hline JF72 & 391807076172802 & HA-88.1056 & 8.28 & HSA & 81 & 76 & -81 & B \\
\hline JF73 & 391807076172803 & HA-88-1057 & 7.48 & HSA & 18 & 15 & -18 & C \\
\hline JF81 & 391808076173001 & HA-88-1059 & 10.01 & HSA & 123 & 120 & -123 & $\mathbf{A}$ \\
\hline JF82 & 391808076173002 & HA-88-1058 & 10.39 & HSA & 75 & 70 & -75 & $B$ \\
\hline JF83 & 391808076173003 & HA-88-1060 & 10.42 & HSA & 20 & 15 & -20 & C \\
\hline JF91 & 391825076172601 & HA-88-1061 & 10.18 & HSA & 79 & 74 & -79 & A \\
\hline $\mathrm{JF} 92$ & 391825076172602 & HA-88-1062 & 10.60 & HSA & 55.5 & 50.5 & -55.5 & B \\
\hline JF93 & 391825076172603 & HA-88-1063 & 10.28 & HSA & 25 & 20 & -25 & C \\
\hline JF101 & 391826076173104 & HA-88-1064 & 5.36 & HSA & 76 & 73 & -76 & A \\
\hline JFIO2 & 391826076173105 & HA-88-1065 & 5.70 & HSA & 55 & 52 & -55 & B \\
\hline JFIO3 & 391826076173106 & HA-88-1066 & 5.41 & HSA & 28 & 25 & -28 & C \\
\hline JF111 & 391826076173101 & HA-88-1067 & 6.51 & HSA & 75 & 69.1 & -75 & $\mathbf{A}$ \\
\hline JF112 & 391826076173102 & HA-88-1068 & 6.19 & HSA & 50 & 47 & -50 & B \\
\hline $\mathrm{JF} 113$ & 391826076173200 & HA-88-1069 & 6.77 & HSA & 25 & 22 & -25 & C \\
\hline JF221 & 391827076173001 & HA-88-1070 & 4.16 & HSA & 70 & 67 & -70 & A \\
\hline JF122 & 391827076173002 & HA-88-1071 & 4.42 & HSA & 55 & 52 & -55 & B \\
\hline JF123 & 391827076173003 & HA-88-1072 & 4.15 & HSA & 28 & 25 & -28 & C \\
\hline
\end{tabular}


downward these are (1) the surficial aquifer, (2) the confining unit, (3) the confined aquifer, and (4) the confining units and confined aquifers in the Patapsco Formation. The focus of this investigation and report is the shallow (less than $150 \mathrm{ft}$ below land surface) ground-water-flow system.

Surficial aquifer.--The surficial aquifer is composed of interbedded sand and clay and is

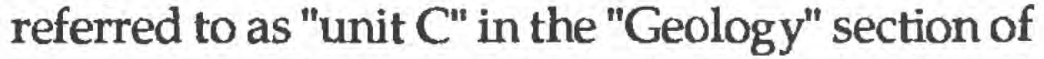
this report. The surficial aquifer is a complex of interfingering sand and clay beds.

The surficial aquifer is about 25 to $40 \mathrm{ft}$ thick and is thickest in the eastern part of the study area (fig. 15). Although, in theory, it is more accurate to describe the surficial aquifer as the saturated part of unit $C$, the entire thickness was mapped because water-level fluctuations are such that it would be difficult to define an average saturated thickness for the entire surficial aquifer. The thickness of the unsaturated zone in unit $\mathrm{C}$ is $0 \mathrm{ft}$ at the edge of the marshes and rivers to as much as $7 \mathrm{ft}$ on the uplands during the dry season.

Horizontal hydraulic conductivity was measured in three wells screened in sand beds in the surficial aquifer (table 7). The values of horizontal hydraulic conductivity ranged from 0.29 to $1.04 \mathrm{ft} / \mathrm{d}$, with a median value of $0.69 \mathrm{ft} / \mathrm{d}$. These values fell within the range described by Todd (1980) for silt to fine sand.

Confining unit.--The confining unit consists of homogeneous silty and sandy clay and is referred to as "unit B" in the "Geology" section of this report. Thin bedding is present in some of the lower parts of the unit and consists of 0.04- to 0.08 -in.-thick beds of clay and silt or clay and fine sand.

The top of the confining unit dips and increases in thickness toward the southeast (figs. 16 and 17). The top of the confining unit is approximately $25 \mathrm{ft}$ below sea level in the western part of the study area and dips to $35 \mathrm{ft}$ below sea level in the eastern part (fig. 16). The thickness of the confining unit increases from approximately $40 \mathrm{ft}$ in the west to $107 \mathrm{ft}$ in the east. This increase in thickness is caused by the filling of the paleochannel by the sediments that compose the confining unit. The confining unit thins toward the north and south margins and is not present outside of the paleochannel (fig. 12).

Slug tests were conducted on four wells screened in the middle of the confining unit (table 7). The values of horizontal hydraulic conductivity ranged from $<0.01$ to $0.20 \mathrm{ft} / \mathrm{d}$; the median value was $0.05 \mathrm{ft} / \mathrm{d}$. The values that were calculated by the Hvorslev (1951) and Cooper (1967) methods were close to each other for three of the wells. For well JF92, the Cooper method could not be used because the data did not fit any of the curves. The range of values of the calculated horizontal hydraulic onductivities falls between the values for silt and clay as given by Todd (1980).

\section{Confined aquifer.--The confined aquifer} consists of sand, gravel, and clay and is referred to as "unit A" in the "Geology" section of this report. The silt and clay content is the most variable component of the unit, with coarse sand and gravel being common at most sites. An exception was at the southeastern end of the toxic-materials disposal area, where the confined aquifer consists of interbedded fine sand and silty clay. The gravel that is common to all of the other sites in this unit was not encountered at these sites.

The top of the confined aquifer is approximately $60 \mathrm{ft}$ below sea level in the western part of the study area and dips to the southeast, where it is $142 \mathrm{ft}$ below sea level (fig. 18). This trend is similar to the trend in the upper surface of the confining unit. The confined aquifer is $50 \mathrm{ft}$ thick in the western part of J-Field and thins to approximately $15 \mathrm{ft}$ to the southeast (fig. 19). Less data were available to construct the confined aquifer-thickness map than were available for the other maps because the observation wells did not fully penetrate the unit and the thickness could only be measured at the seven borehole locations. The margins of the paleochannel that underlies J-Field mark the 
Table 7.--Results of slug tests

[--, could not be determined; $<$, less than]

\begin{tabular}{|c|c|c|c|c|c|}
\hline $\begin{array}{l}\text { Well } \\
\text { no. }\end{array}$ & $\begin{array}{l}\text { Length } \\
\text { of screen } \\
\text { (ft) }\end{array}$ & $\begin{array}{l}\text { Screen } \\
\text { opening } \\
\text { (in.) }\end{array}$ & $\begin{array}{l}\text { Hydraulic } \\
\text { Hvorslev } \\
\text { method } \\
\text { (ft/d) }\end{array}$ & $\begin{array}{l}\text { c conductivity } \\
\text { Cooper } \\
\text { method } \\
(\mathrm{ft} / \mathrm{d})\end{array}$ & $\begin{array}{l}\text { Hydrologic } \\
\text { unit }\end{array}$ \\
\hline JF3 & 5 & 0.001 & 0.70 & 1.04 & Surficial \\
\hline JF93 & 5 & .01 & .29 & - & aquifer \\
\hline JF113 & 3 & .01 & .69 & .58 & \\
\hline JF32 & 5 & .001 & .05 & .09 & Confining \\
\hline JF42 & 5 & .06 & $<.01$ & .02 & unit \\
\hline JF92 & 5 & .06 & .20 & - & \\
\hline JF31 & 5 & .001 & 13.6 & 51.8 & Confined \\
\hline JF41 & 5 & .01 & 272 & 932 & aquifer \\
\hline JF91 & 5 & .001 & 3.16 & 7.41 & \\
\hline JF111 & 5 & .01 & 111 & 508 & \\
\hline $\mathrm{JF} 2$ & 5 & .01 & .61 & .06 & $\begin{array}{l}\text { Patapsco } \\
\text { Formation }\end{array}$ \\
\hline
\end{tabular}

edge of the confined aquifer (fig. 12).

The horizontal hydraulic conductivity of the confined aquifer was measured by slug tests (table 7). The variation in the material comprising this aquifer is reflected in the range of values for horizontal hydraulic conductivity. In wells JF31 and JF91, the abundance of silt and clay in the aquifer resulted in horizontal hydraulic conductivity values of 3.16 to $51.8 \mathrm{ft} / \mathrm{d}$, with a median value of $10.5 \mathrm{ft} / \mathrm{d}$. Where the aquifer contained only minor amounts of fine materials, such as in wells JF41 and JF111, the horizontal hydraulic conductivities were much higher than in other wells--from 111 to $932 \mathrm{ft} / \mathrm{d}$, with a median value of $390 \mathrm{ft} / \mathrm{d}$.

\section{Patapsco Formation.--The Patapsco}

Formation extends laterally over a much greater area than do the Pleistocene units, and contains numerous discontinuous sand and clay beds. The degree of hydraulic connection between sand beds is high because of the discontinuous nature of the clay beds. For the purposes of this investigation, the Patapsco Formation is classified as a single hydrologic unit on the basis of the limited data available.

The altitude of the upper surface of the Patapsco Formation is shown in figure 20. The top of this unit ranges from $105 \mathrm{ft}$ in the east to $157 \mathrm{ft}$ below sea level in the western part of the study area. The upper surface of the Patapsco Formation represents the base of the Pleistocene paleochannel that was carved into the Cretaceous sediments. The deepest part of the channel that was identified is located to the southeast near well JF2. Approximately $120 \mathrm{ft}$ of Patapsco Formation was penetrated by the deepest borehole drilled at J-Field. The complete thickness of the unit in this area is not known but could be as much as $300 \mathrm{ft}$.

The horizontal hydraulic conductivity of the clay beds in the Patapsco Formation is almost certainly low. Most sand beds in the Patapsco are fine grained, suggesting a moderate-to-low hydraulic conductivity. The horizontal hydraulic conductivity of one sand unit in the Patapsco was measured in well JF2 as approximately $0.61 \mathrm{ft} / \mathrm{d}$ by Hvorslev's method (1951) and $0.06 \mathrm{ft} / \mathrm{d}$ with Cooper's method (1967). These values fall within the fine-sand to silt range given by Todd (1980). Horizontal hydraulic conductivities measured in the Patapsco in the Canal Creek Area of APG (fig. 1) ranged from 0.01 to $176 \mathrm{ft} / \mathrm{d}$, with a median value of $23 \mathrm{ft} / \mathrm{d}$ (Oliveros and Vroblesky, 1989).

\section{Head distribution and flow directions}

In general, horizontal ground-water flow is from topographically high areas to topographically low areas. In the study area, the low areas are marshs or estuaries. In the deeper aquifers, the direction of ground-water flow depends primarily on the level of the tide, but the net flow is probably away from J-Field and toward the estuaries. Vertical ground-water flow beneath $\mathrm{J}$ Field is downward, flowing from the surficial aquifer to the confined aquifer. The vertical flow is probably small compared to that of horizontal flow in the surficial aquifer because of the low hydraulic conductivity of the confining unit 


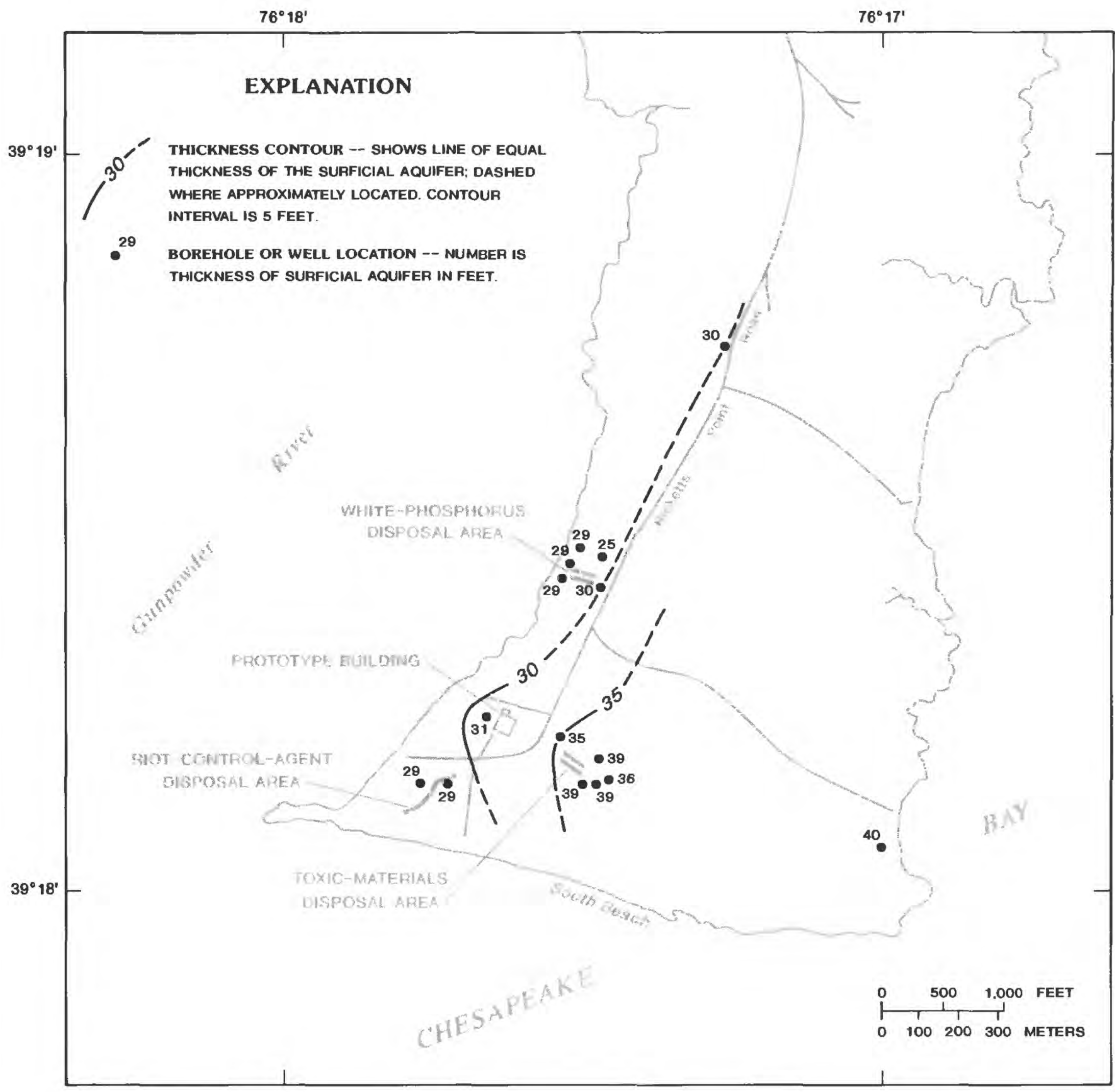

Figure 15.--Thickness of the surficial aquifer. 


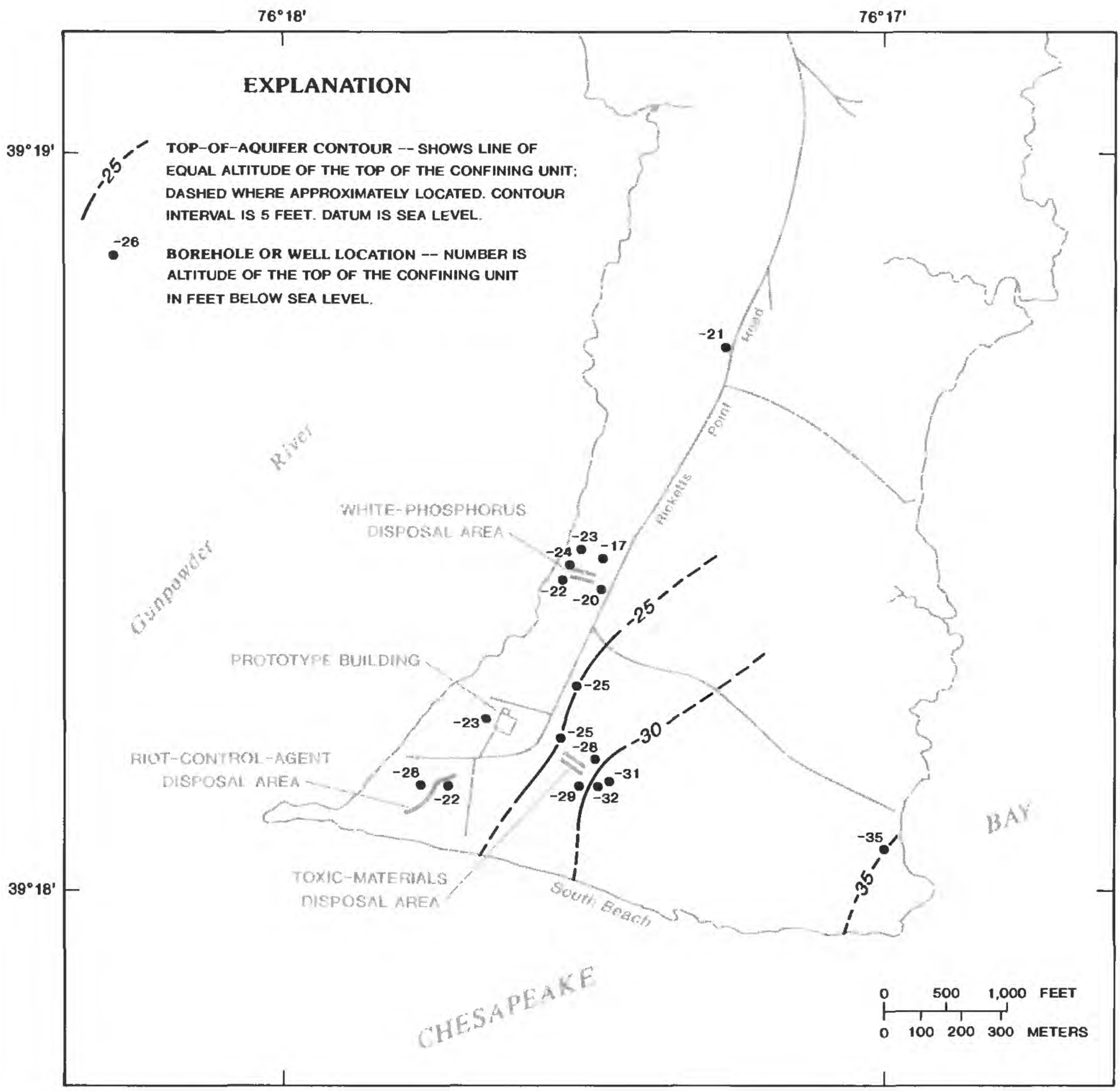

Figure 16.--Altitude of the top of the confining unit. 


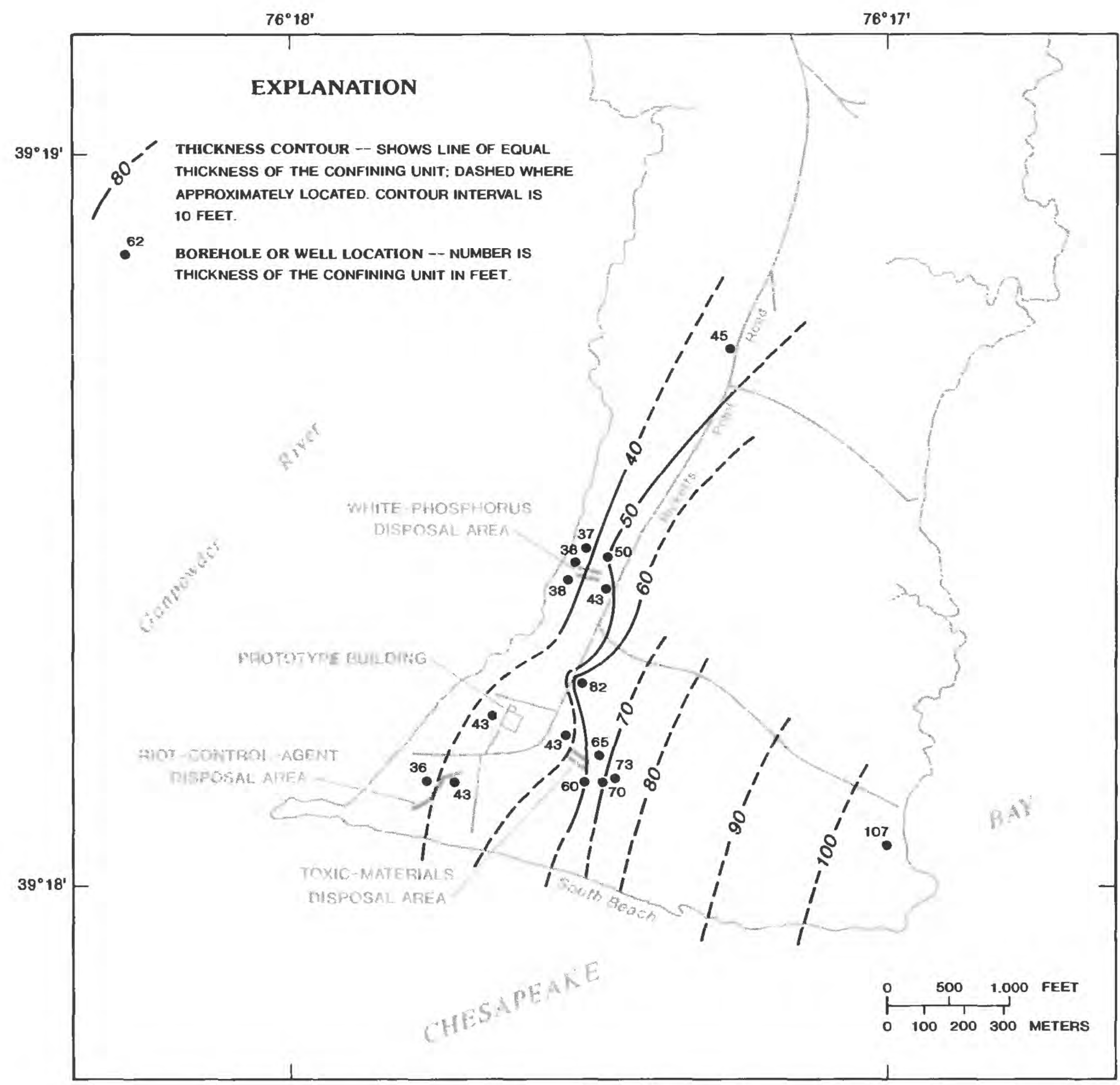

Figure 17.--Thickness of the confining unit. 


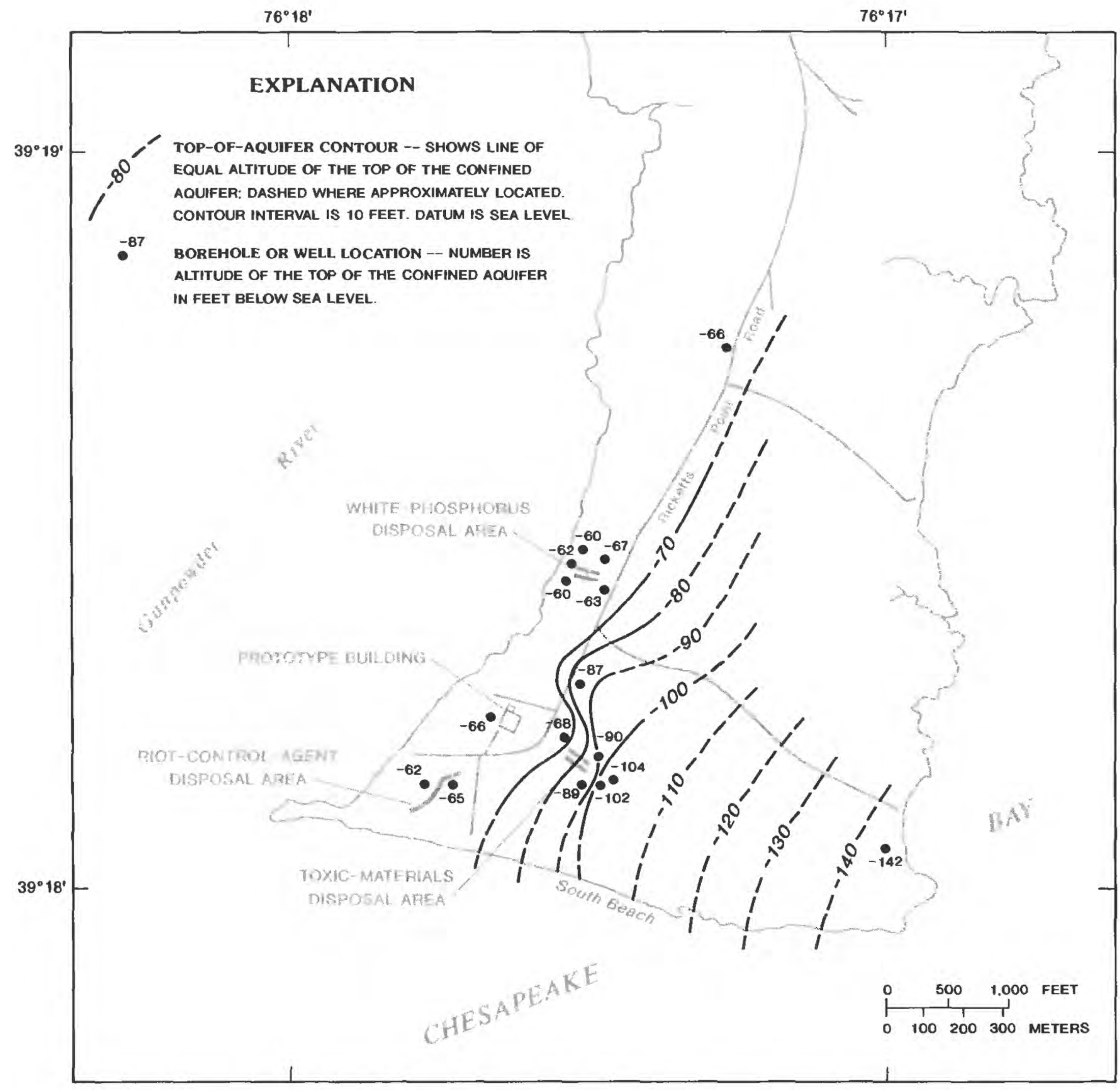

Figure 18.--Altitude of the top of the confined aquifer. 


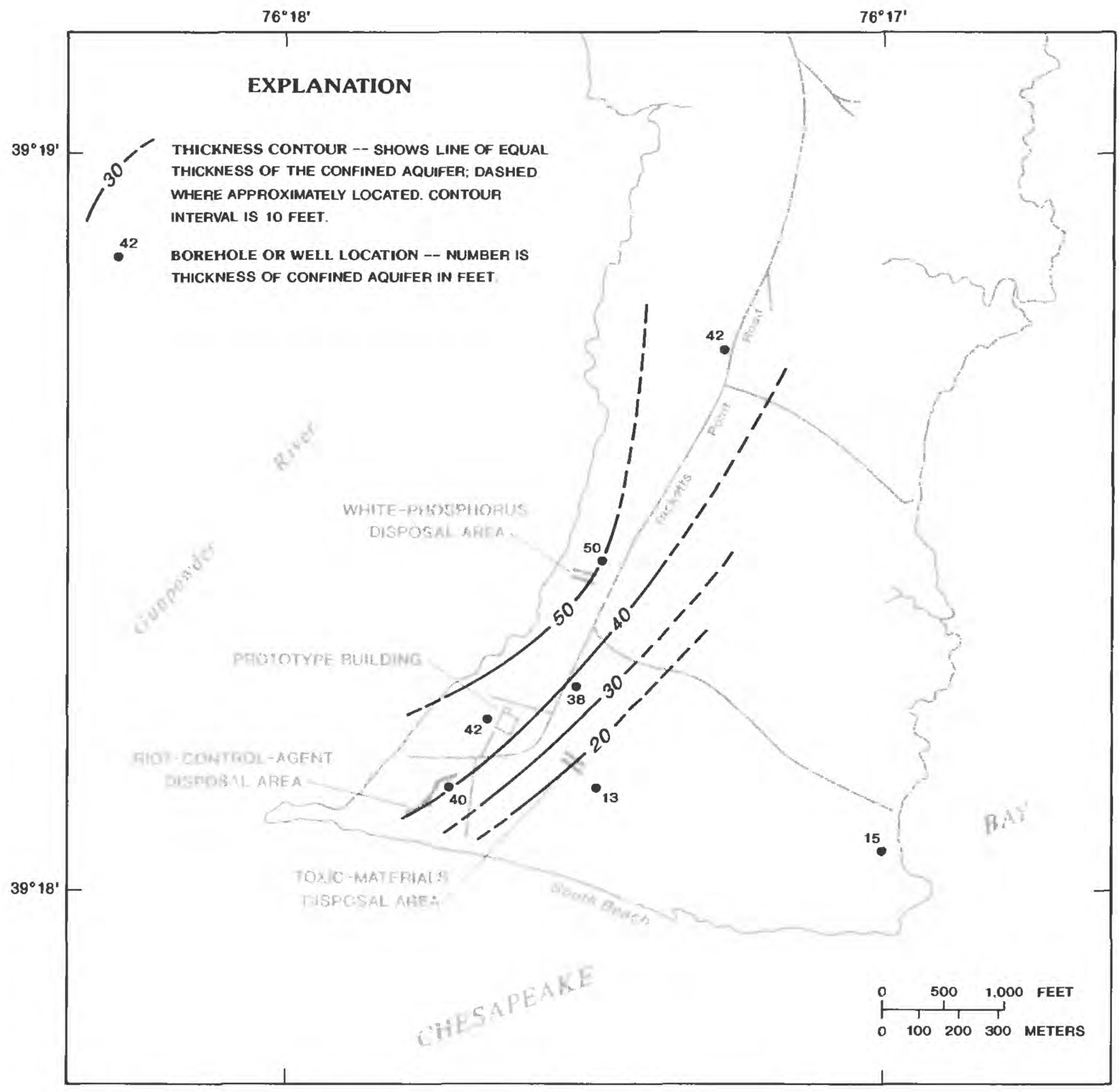

Figure 19.--Thickness of the confined aquifer. 


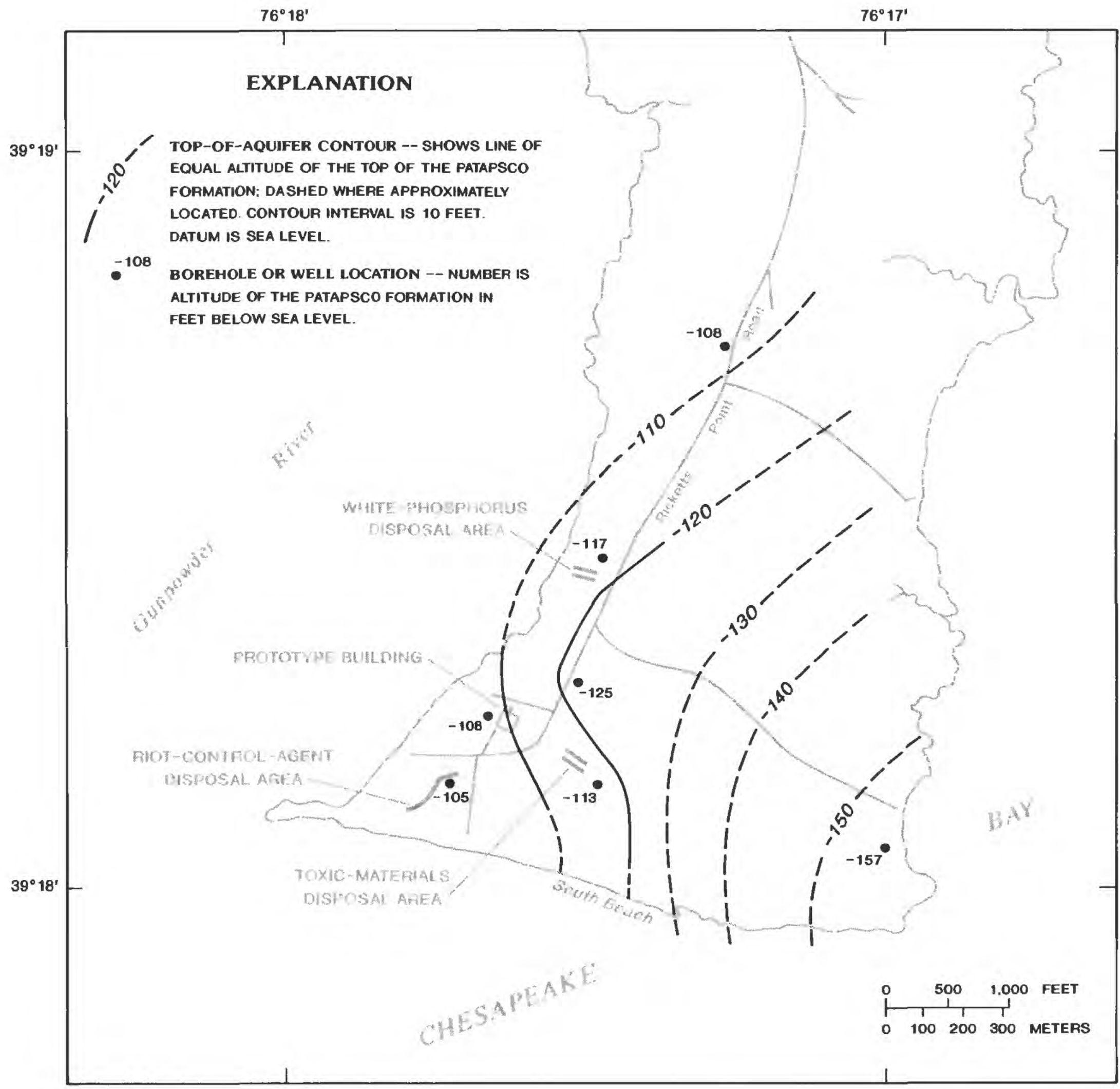

Figure 20.--Altitude of the top of the Patapsco Formation. 
In offshore areas, the direction of ground-water flow is vertically upward to the Chesapeake Bay or Gunpowder River.

Surficial aquifer--The hydraulic-head distribution and ground-water-flow directions in the surficial aquifer are shown in figure 21 . The configuration of the water table is usually a subdued representation of the land surface topography-that is, the highest water-level altitudes are associated with the highest land-surface elevations and vice versa (fig. 2). Ground-water altitudes ranged from more than $6 \mathrm{ft}$ to less than $2 \mathrm{ft}$ above sea level in November 1989. Ground water in the surficial aquifer flows from the uplands toward lowland discharge areas in adjacent marshes or estuaries (fig. 21). The surficial aquifer receives recharge primarily from rainfall. During drought conditions, however, groundwater levels can fall below surface-water levels, allowing minor amounts of surface water from the surrounding estuaries to enter the groundwater system. Water levels measured during September 1987 in some wells were slightly lower than sea level. Under these head conditions, estuary water could have flowed laterally into the surficial aquifer during high tides.

The steepest hydraulic gradients in the surficial aquifer were observed near the toxicmaterials disposal area and the white-phosphorus disposal area. Both of these disposal areas are located near the highest uplands in J-Field (fig. 3). The highest water-table altitudes are associated with the uplands at the eastern end of the white-phosphorus disposal area and at the western end of the toxic-materials disposal area (fig. 21). Ground-water flow is from these areas toward the marsh or river. Ground-water flow in the surficial aquifer at the riot-control-agent disposal area is from the upland at the northern end of the pit, toward the Gunpowder River and Chesapeake Bay (fig. 21).

The surficial aquifer consists of deposits of variable permeability (table 8 ). The vertical head gradient within the surficial aquifer is unknown because the wells were only screened at a single depth in this unit at each well cluster. It is likely that this gradient is not large. Wells constructed for the Princeton Aqua Science (1984) study were screened in more than one permeable zone within the surficial aquifer. Heads measured in the Princeton Aqua Science wells were similar to those in the wells that were screened in a single permeable zone.

The vertical head gradient between the surficial aquifer and the underlying confining unit is downward, indicating that some ground water is flowing from the surficial aquifer through the confining unit. Because the horizontal hydraulic conductivity of the confining unit is approximately one order of magnitude less than that of the surficial aquifer (table 7), the amount of vertical ground-water flow through the confining unit is probably much smaller than the amount of horizontal flow in the surficial aquifer.

Confining unit.--The hydraulic-head distribution and the ground-water-flow direction in the confining unit are similar to those in the surficial aquifer (fig. 22). The hydraulic heads in the confining unit, however, are about $2 \mathrm{ft}$ lower than those in the surficial aquifer. The cverall flow pattern is from the uplands toward the lowlands adjacent to the marshes or estuaries.

Recharge to the confining unit comes primarily from the overlying surficial aquifer. The vertical head gradient between these two units is approximately $3 \mathrm{ft}$ in upland areas and 1 $\mathrm{ft}$ near the rivers. In offshore areas, the vertical head gradient could be upward or downward but is probably extremely small. An upward head gradient would cause water from the confining unit to flow upward into the sediments that compose the surficial aquifer in offshore areas and eventually into the Chesapeake Bay or Gunpowder River. A downward gradient would cause river water to flow vertically through the surficial aquifer and into the confining unit. In either case, the volume of water that flows into or out of the confining unit is probably quite small when compared to that flowing laterally through the surficial aquifer. 


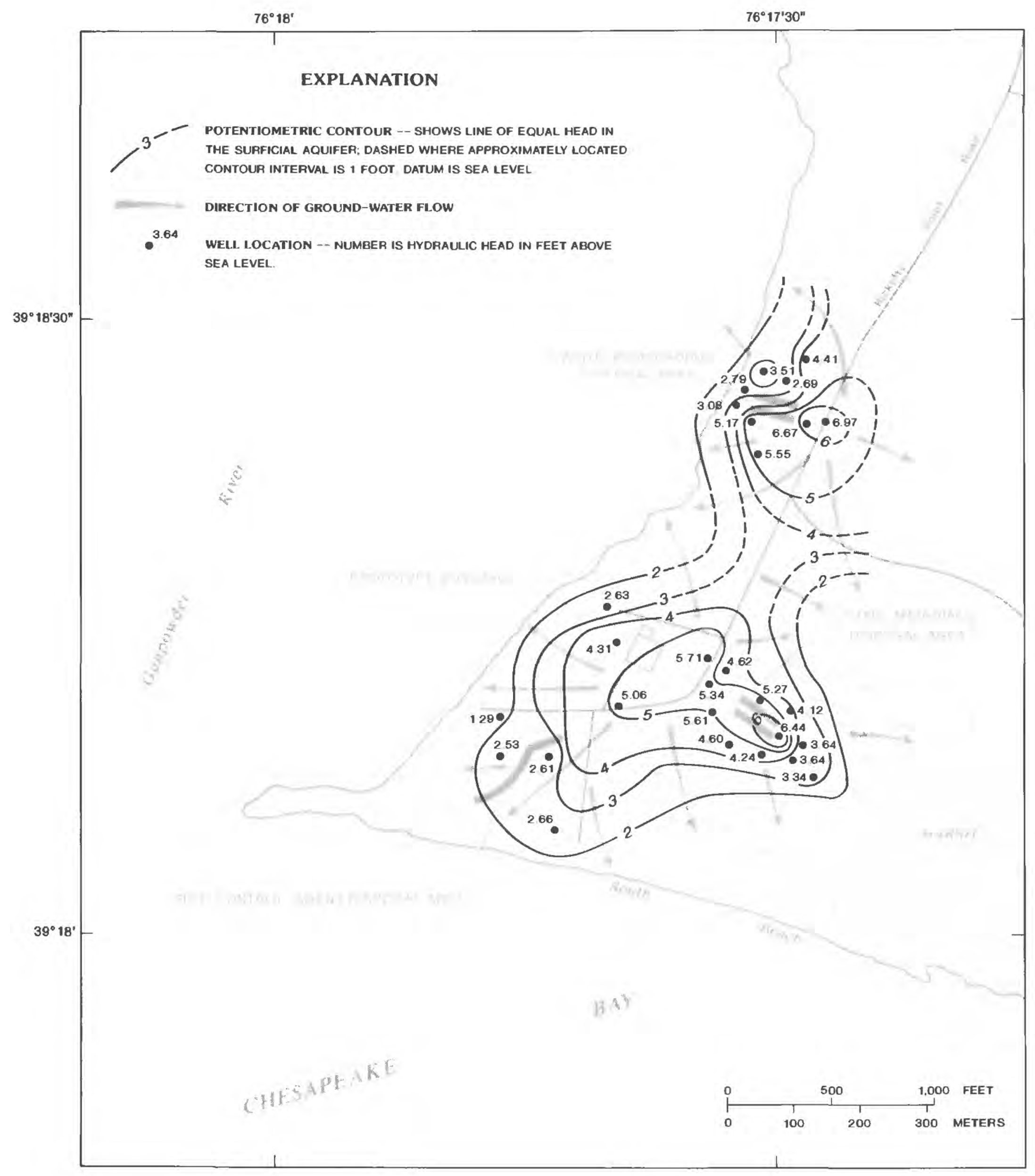

Figure 21.--Hydraulic head and direction of ground-water flow in the surficial aquifer, November 1989. 


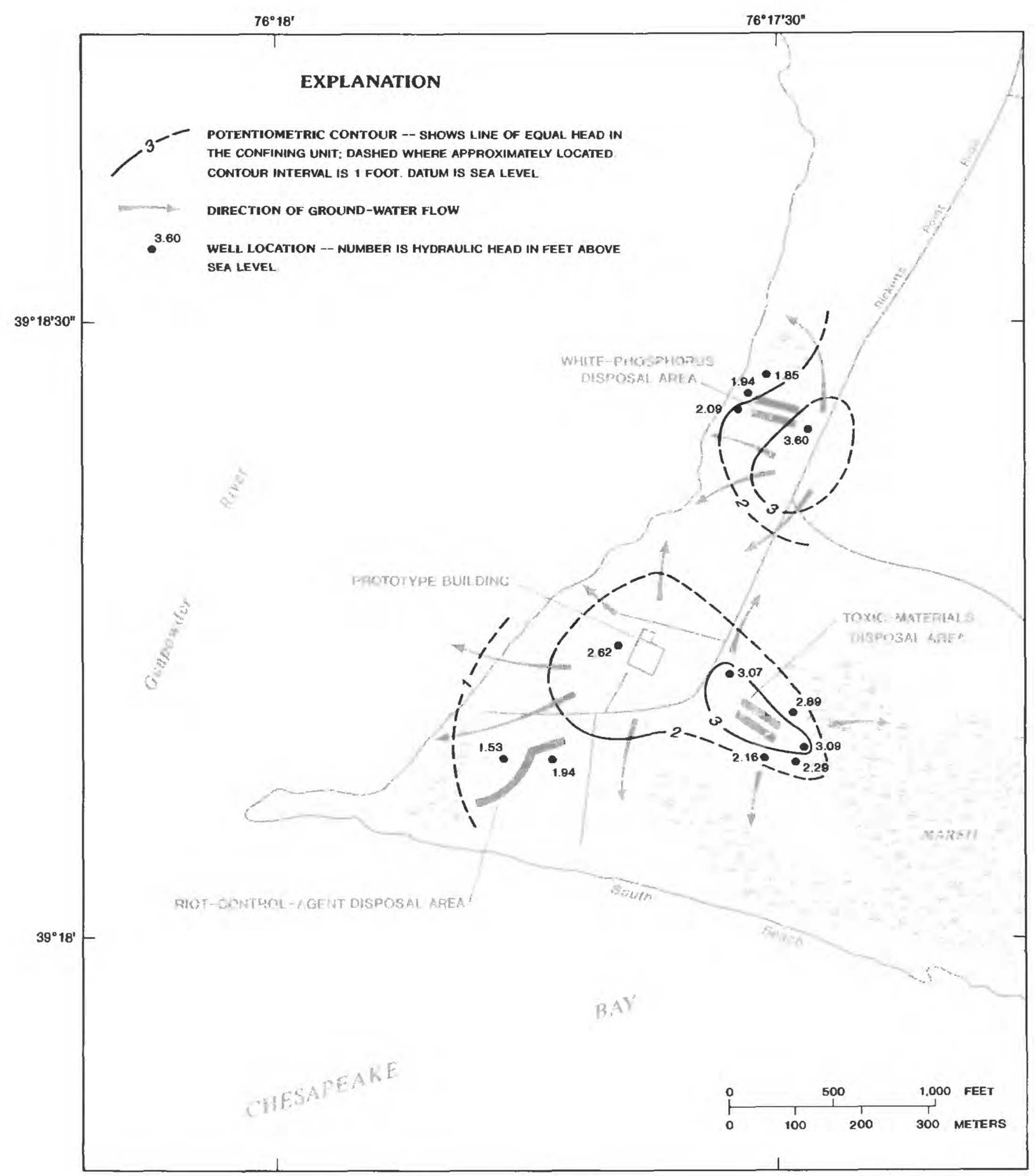

Figure 22.--Hydraulic head and direction of ground-water flow in the confining unit, November 1989. 
Ground water flows vertically from the confining unit to the underlying confined aquifer at all of the sites beneath J-Field. The vertical head gradient between these two units is approximately $1 \mathrm{ft}$ in the upland areas and decreases toward the shore. The vertical head gradient between the confining unit and the confined aquifer is probably quite small in offshore areas, resulting in minimal flow between the two units.

Ground water in the offshore areas of J-Field is likely to be flowing upward, because the estuaries are discharge areas for the regional ground-water-flow system (Otton and Mandle, 1984). There is some evidence that the flow direction between the confining unit and the surficial aquifer could reverse in offshore areas. The hydraulic head in the confining unit at site 11 (fig. 14) is greater than those in the surficial aquifer and the confined aquifer, indicating that, in this area, ground water is flowing from the confining unit into the underlying and overlying units. The wells in these units are located approximately $20 \mathrm{ft}$ from the Gunpowder River, where a reversal in gradient might be observed in onshore wells. At this location, the flow has not completely reversed from downward into the confined aquifer to upward into the surficial aquifer. Farther offshore, the reversal is probably more complete than it is closer to shore, where ground water flows from the confined aquifer, through the confining unit and surficial aquifer, and finally discharges into the Gunpowder River. The net upward flow is likely to be small because of the small vertical head gradients in offshore areas and the low horizontal hydraulic conductivity of the confining unit.

Confined aquifer.--The head distribution and ground-water-flow directions in the confined aquifer are shown in figure 23 . The heads are higher beneath the uplands near the toxicmaterials disposal area. The pattern of heads in this area is similar to patterns in the surficial aquifer and confining unit, but the heads are lower and the lateral gradients are extremely small. The lateral head distribution at the white- phosphorus disposal area, however, is reversed from those in the overlying units. The highest head is adjacent to the Gunpowder River and the lowest head was measured at the eastern end of the disposal pits.

Although the confined aquifer has a high horizontal hydraulic conductivity, the lateral head gradient in the aquifer is small and lateral flow is probably small. At the white-phosphorus disposal area, the hydraulic-head map indicates that flow is from the shore of the Gunpowder River toward the peninsula. The water level in the confined aquifer, however, is essentially the same at the eastern and western ends of the white-phosphorus disposal area for much of the year. The head at the eastern end of the pits is lower than the head at the western end only during July and August, when recharge is least. The net lateral flow of ground water in the confined system is probably toward the marsh and rivers, but the flow reverses at times because of low summer recharge and from tidal fluctuations.

The general direction of vertical groundwater flow is from the confining unit downwards into the confined aquifer in onshore areas. This relation could reverse in offshore areas because the head in the confined aquifer is fairly constant across the study area, whereas the head in the surficial aquifer approaches the river stage at the shoreline. The net vertical flow of ground water in offshore areas is probably small, however, because of the small vertical head gradient across the confining unit and the low horizontal hydraulic conductivity of the confining unit.

Patapsco Formation.--Only three hydraulic heads were measured in the Patapsco Formation (at well JF1): $2.40 \mathrm{ft}$ above sea level, October $1989 ; 1.91 \mathrm{ft}$ above sea level, April $1990 ; 0.82 \mathrm{ft}$ above sea level, July 1990. The heads in the Patapsco Formation were similar to those measured in the confined aquifer, but because of the distance between the Patapsco Formation wells and the nearest confined aquifer wells, the vertical gradient could not be determined. It is possible that the local-flow system does not affect the heads in the Patapsco Formation significantly. Ground-water flow in this unit is 


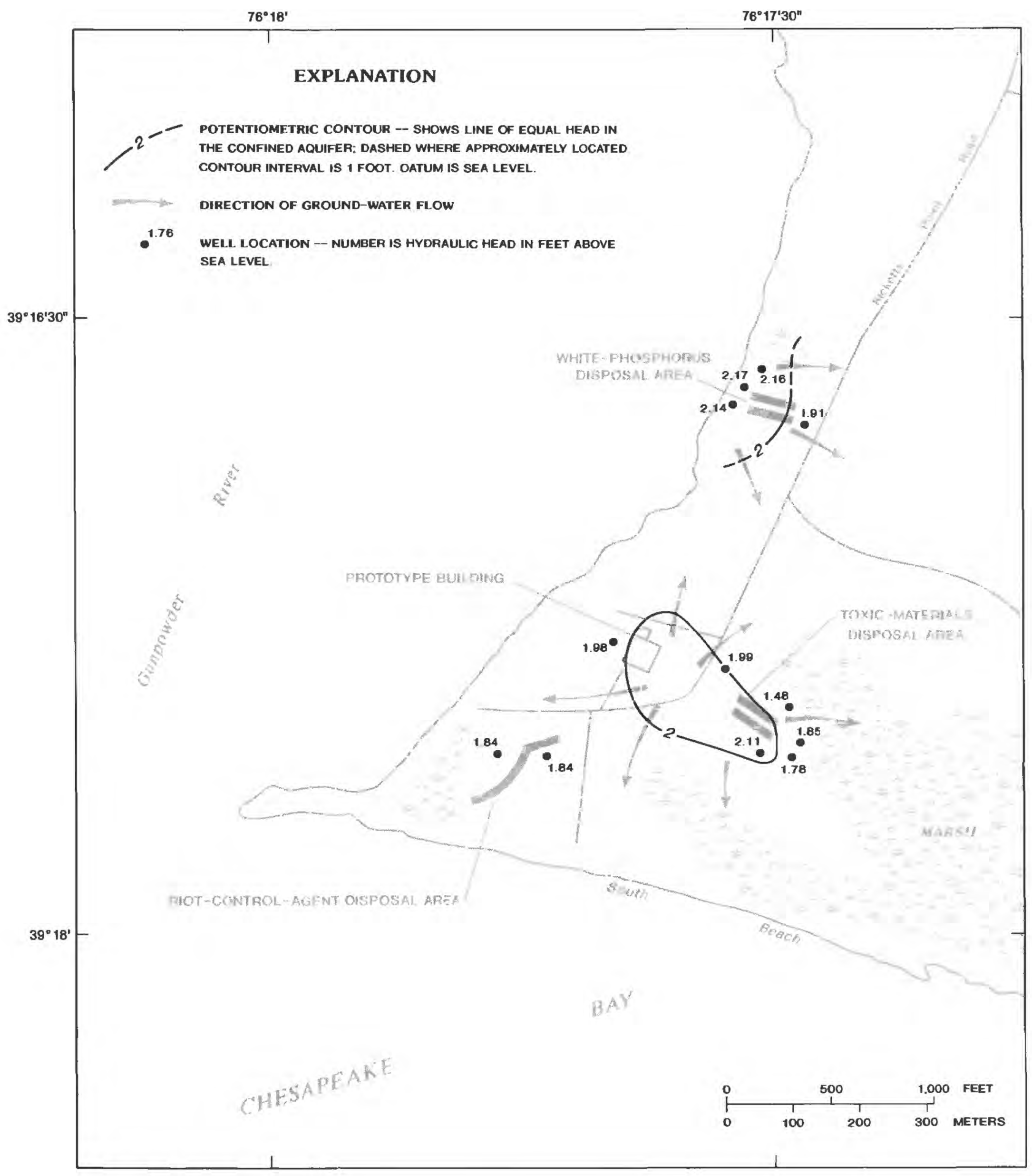

Figure 23.--Hydraulic head and direction of ground-water flow in the confined aquifer, November 1989. 
controlled by the large flow system of recharge on the western side of the Chesapeake Bay and discharge into the Bay.

\section{Seasonal and tide-induced fluctuations}

Seasonal fluctuations of water levels were observed in all the hydrologic units screened by wells at J-Field. Effective recharge is greatest in winter, when the highest water levels were measured, and least in summer, when the lowest water levels were measured. Tidal fluctuations were observed in the surficial aquifer and in the confined aquifer.

Surficial aquifer.--The closest pumpage of ground water in the vicinity of J-Field is located approximately $4 \mathrm{mi}$ away, across the Gun-powder River. Because there is no nearby pumpage, the major influences on the shallow flow system are recharge, evapotranspiration, and tidal fluctuations. The water level in the surficial aquifer responds quickly to summer recharge events and more slowly to those in winter (figs. 24-29). From January 1990 through September 1990, effective recharge was greatest in winter and least in late summer. The primary control on recharge is the high rate of evapotranspiration in the summer. Because of low water levels during the summer months, the slow downward flow of water from the surficial aquifer to the confining unit was reversed at sites 1, 2, and 9 (figs. 24, 25, and 28) for short periods in July and August 1990. At site 11, ground water flowed upward throughout the year (fig. 29).

Water levels in the surficial aquifer were highest from January through May 1990 (figs. 24-29). Water levels were 3 to $6 \mathrm{ft}$ above sea level during this period. In the summer months of June, July, and August 1990, water levels averaged 1 to $3 \mathrm{ft}$ lower than from January through May. During the period of record, storms caused water levels to rise no more than $1 \mathrm{ft}$ during a period of several days, except at site 3 , where water levels rose as much as $2.5 \mathrm{ft}$ in 1 day.

The tides in the adjacent estuaries affect the water levels in some of the surficial-aquifer wells. Water-leveI records from two wells constructed during the USATHAMA study (Nemeth and others, 1983) were used to compare water-level fluctuations with tide data (fig. 30). Use of the USATHAMA study wells was necessary because a tide gage located at Robbins Point was destroyed by winter ice in January 1989 , before the water-level recorders were installed on the USGS observation wells. Well TH8 is located approximately $100 \mathrm{ft}$ and well $\mathrm{TH} 3$ approximately $250 \mathrm{ft}$ from the shore of the Gunpowder River (fig 5). Well TH7 is located in the middle of J-Field approximately $1200 \mathrm{ft}$ from the Chesapeake Bay. A tidal fluctuation of $2 \mathrm{ft}$ in the Chesapeake Bay causes a response of approximately $0.5 \mathrm{ft}$ in well $\mathrm{TH} 8$, a response of 0.2 ft in well TH3, and $0.1 \mathrm{ft}$ in well TH7 (fig. 30). Clearly, the wells that are most affected by tides are those nearest the shore, such as TH8. Tidal fluctuations in the surficial aquifer result from a direct hydraulic connection between the aquifer and the river.

Confining unit.--The water-level altitude in the confining unit varies seasonally, depending on the amount of recharge received by the surficial aquifer (figs. 24-29). The pattern is similar to that observed in the surficial aquifer but is much more subdued. The greatest response to water level changes in the surficial aquifer occurred at sites 3,9 , and 11 (figs. 26, 28, and 29); a more subtle response occurred at sites 1,2 , and 4 (figs. 24, 25, and 27). The smallest response and the lowest measured horizontal hydraulic conductivity in the confining unit were found at site 4 , indicating that horizontal hydraulic conductivity exerts some control on the response of the water level in the confining unit; however, factors such as proximity to shore, thickness of confining unit, depth to confining unit, and screened interval can also be major influences.

During late summer, when effective recharge is low, the head gradient between the confining unit and the surficial aquifer occasionally reverses. The largest vertical head gradients, when reversed, were approximately $0.67 \mathrm{ft}$ at site $1,0.3 \mathrm{ft}$ at site 2 , and $0.2 \mathrm{ft}$ at site 9 . The reversal was observed continuously for as long as 25 days at of site 1 (fig. 24), and intermittently for several days at sites 2 and and 9 (figs. 25 and 28). 

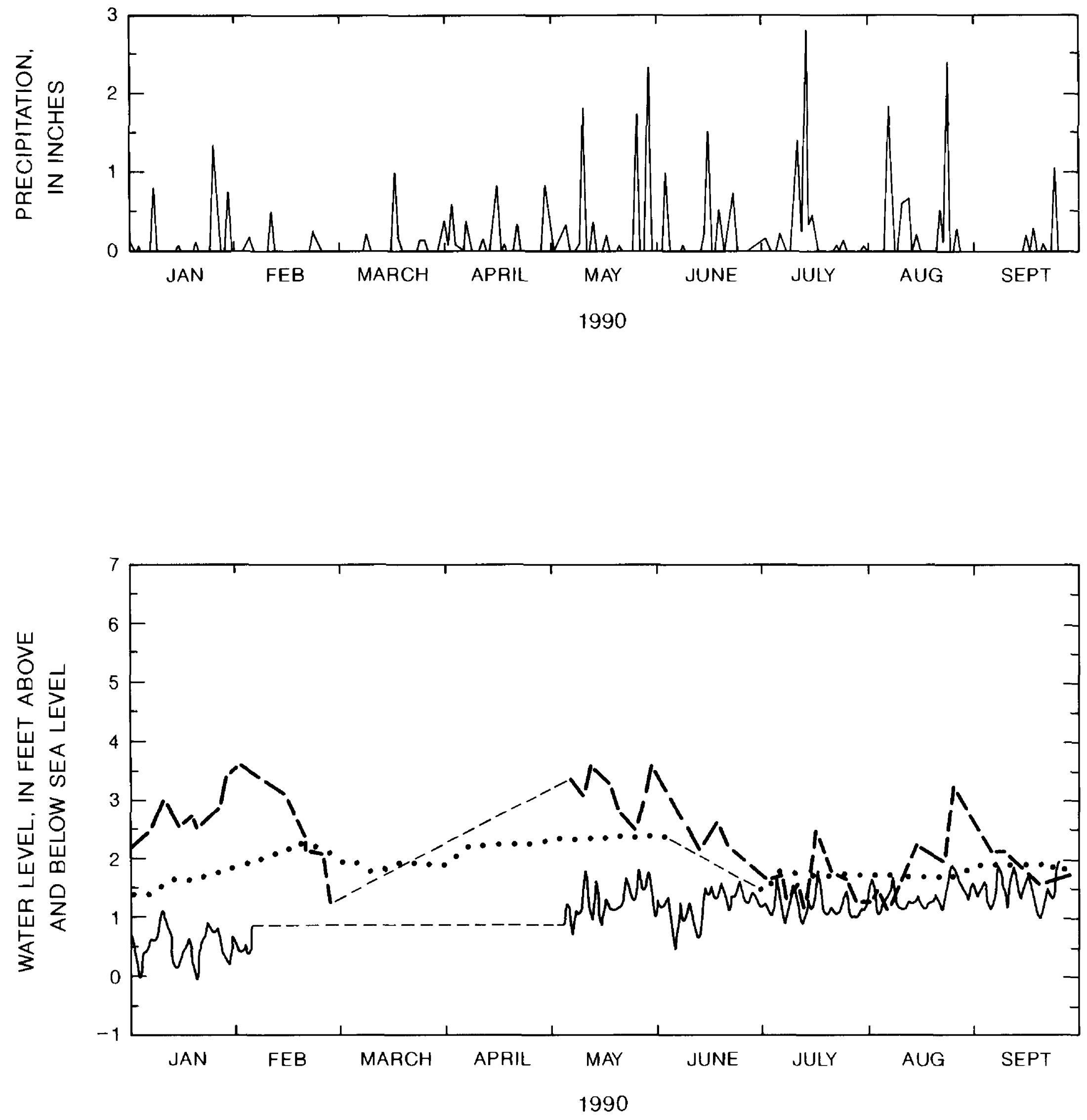

EXPLANATION

- - SURFICIAL AQUIFER (WELL 13)

.... CONFINING UNIT (WELL 12)
W CONFINED AQUIFER (WELL 11)

MISSING DATA

Figure 24.--Daily precipitation and water-level altitudes in wells at U.S. Geological Survey well-cluster site 1 at J-Field. 

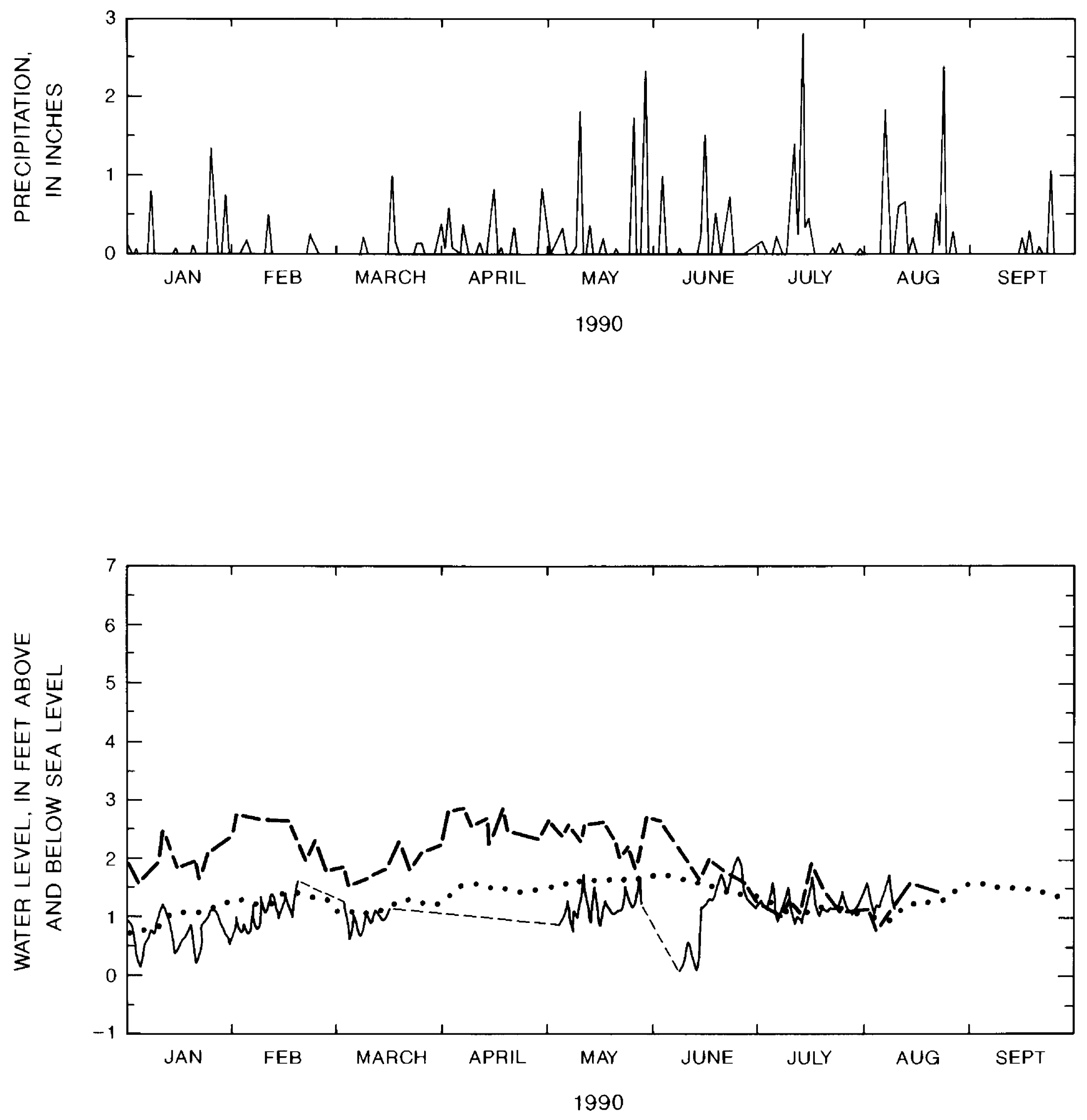

EXPLANATION

- - SURFICIAL AQUIFER (WELL 23)

W CONFINED AQUIFER (WELL 21)

.... CONFINING UNIT (WELL 22)

MISSING DATA

Figure 25.--Daily precipitation and water-level altitudes in wells at U.S. Geological Survey well-cluster site 2 at J-Field. 

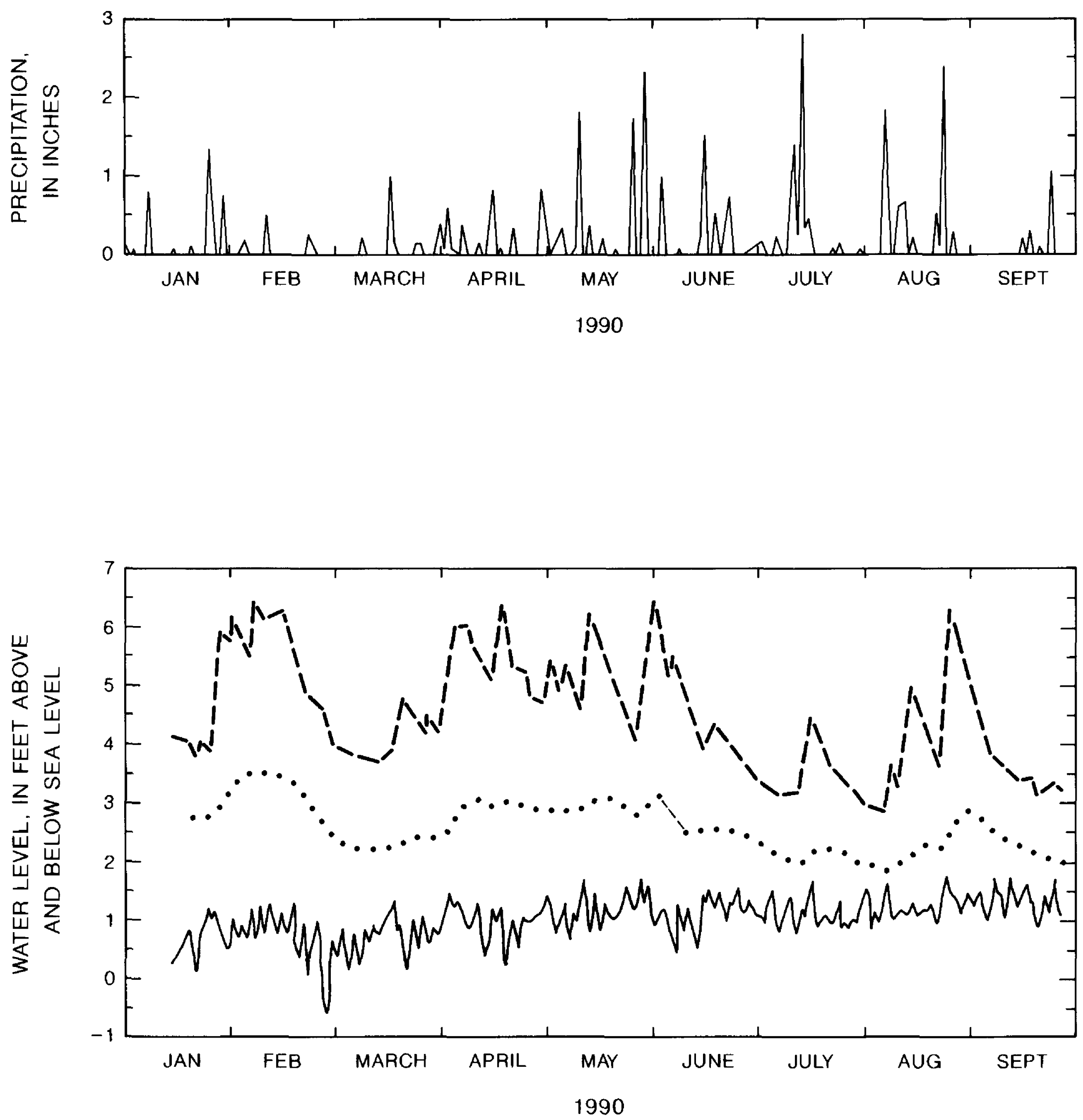

EXPLANATION

- - SURFICIAL AQUIFER (WELL 33)

.... CONFINING UNIT (WELL 32)
WN CONFINED AQUIFER (WELL 31)

MISSING DATA

Figure 26.--Daily precipitation and water-level altitudes in wells at U.S. Geological Survey well-cluster site 3 at J-Field. 

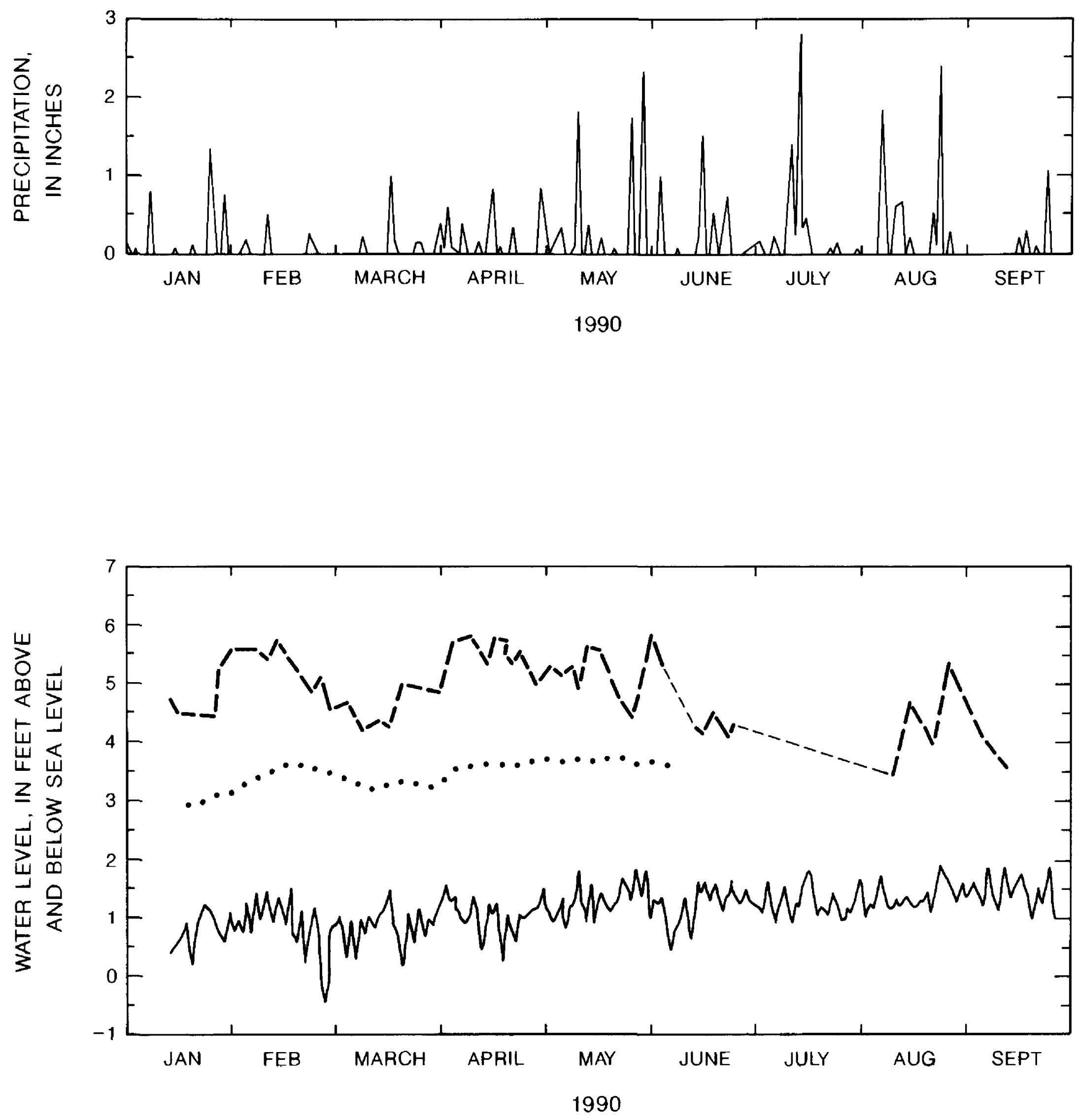

EXPLANATION

- - SURFICIAL AQUIFER (WELL 43)

W $ר$ confINED AQUIFER (WELL 41)

.... CONFINING UNIT (WELL 42)

MISSING DATA

Figure 27.--Daily precipitation and water-level altitudes in wells at U.S. Geological Survey well-cluster site 4 at J-Field. 

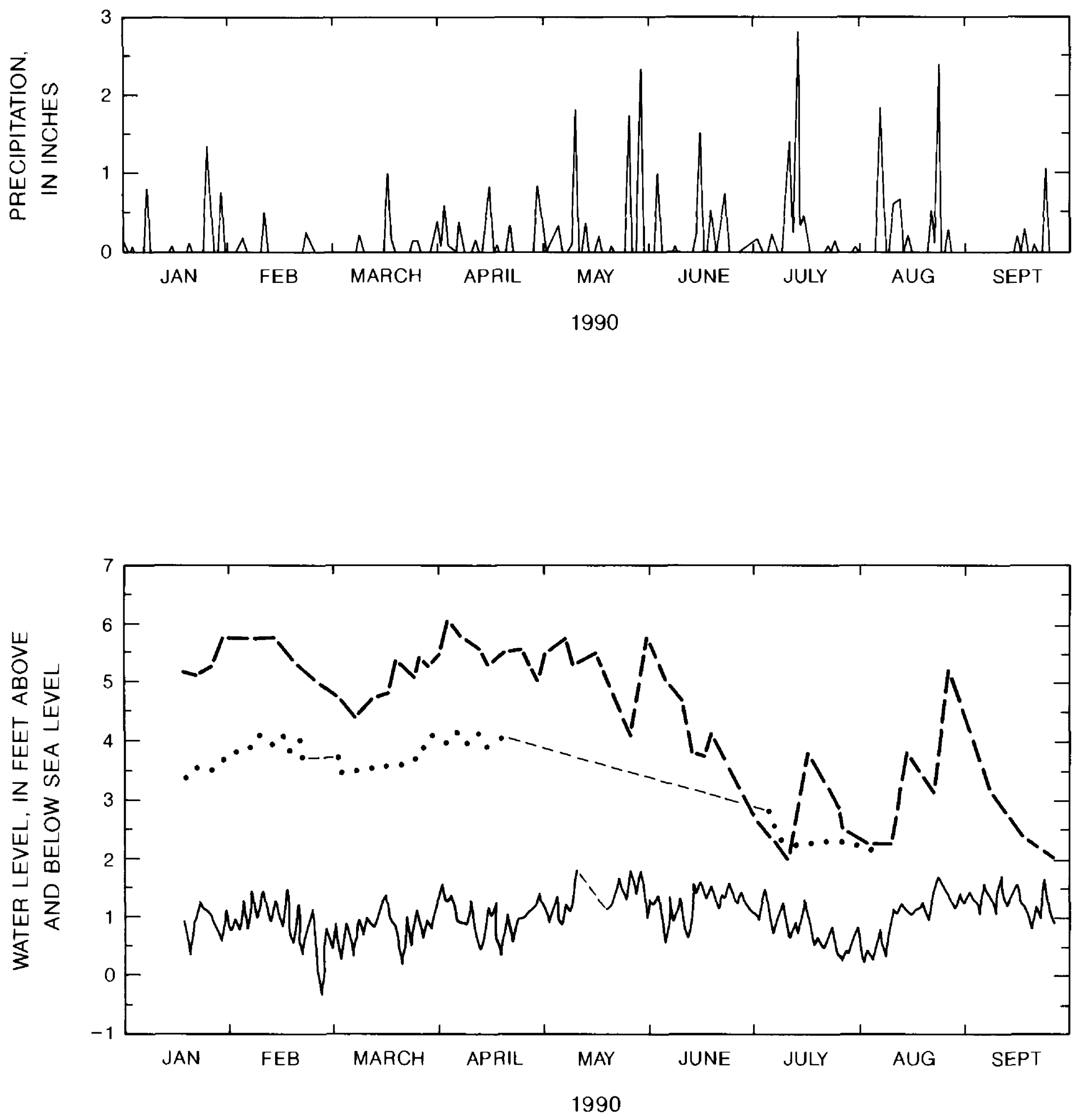

EXPLANATION

- - SURFICIAL AQUIFER (WELL 93)

רN cONFINED AQUIFER (WELL 91)

.... CONFINING UNIT (WELL 92)

MISSING DATA

Figure 28.--Daily precipitation and water-level altitudes in wells at U.S. Geological Survey well-cluster site 9 at J-Field. 

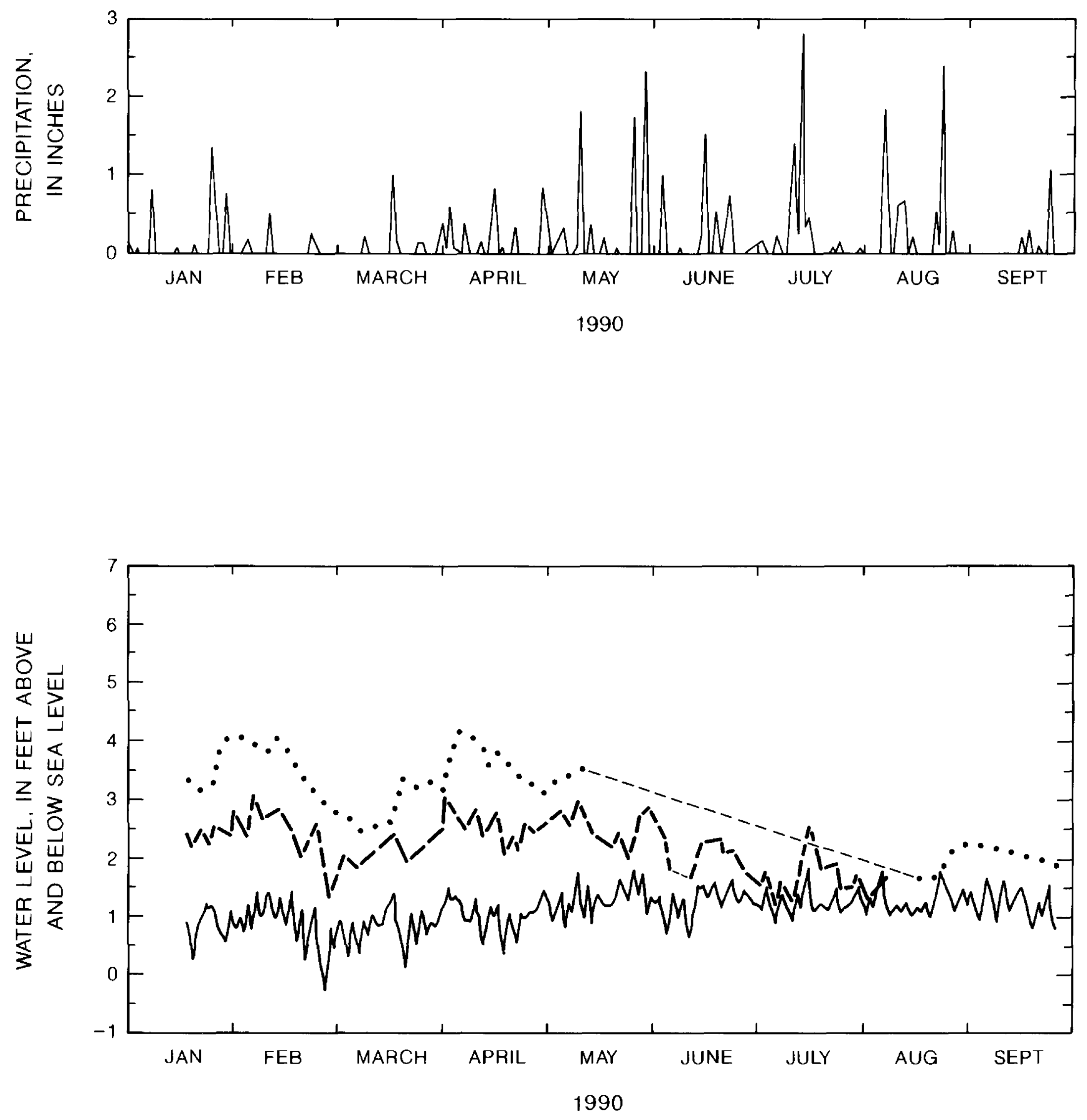

EXPLANATION

- - SURFICIAL AQUIFER (WELL 113)

CONFINING UNIT (WELL 112)
ר coNFINED AQUIFER (WELL 111)

MISSING DATA

Figure 29.--Daily precipitation and water-level altitudes in wells at U.S. Geological Survey well-cluster site 11 at J-Field. 


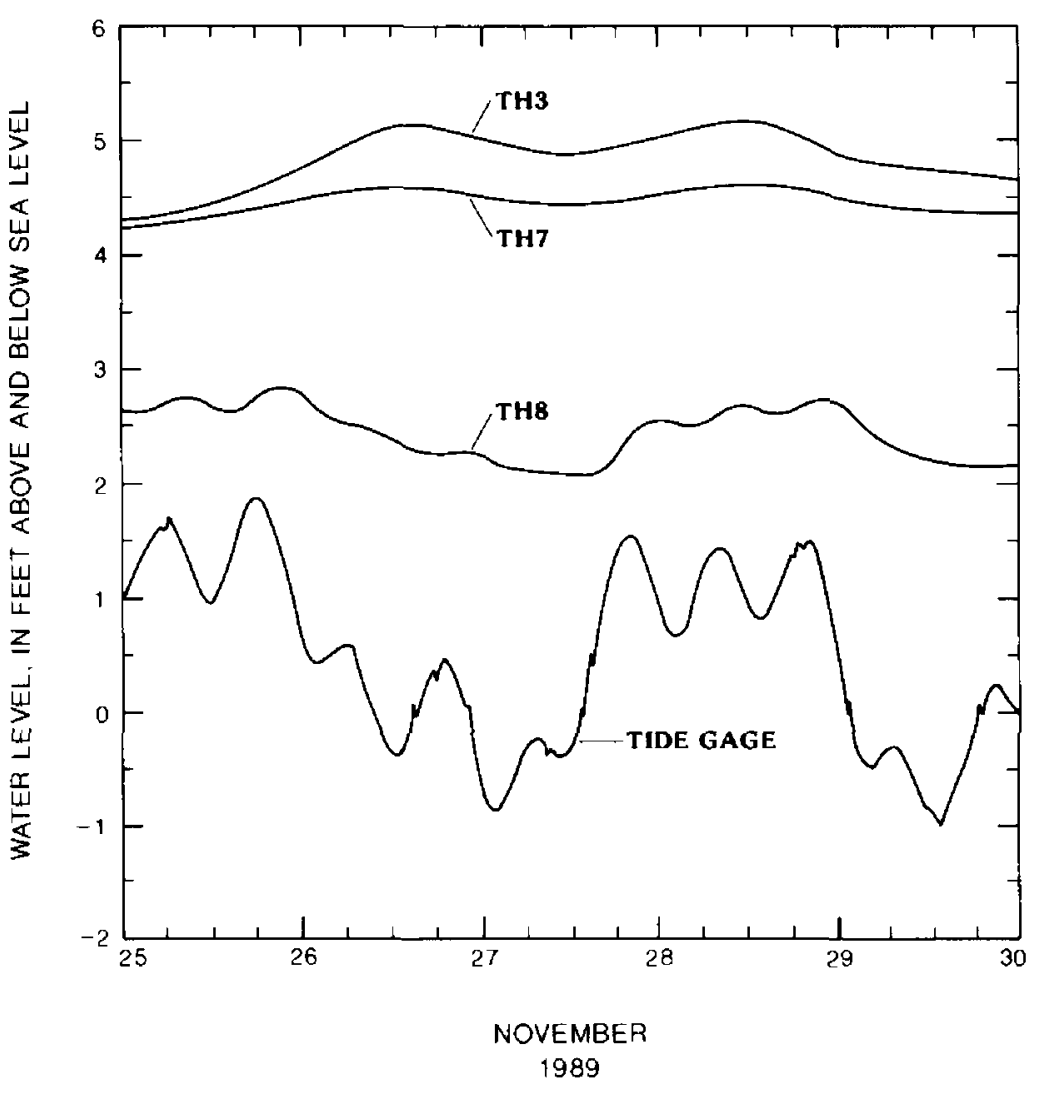

Figure 30.--Tidal fluctuations in the Chesapeake Bay and water-level altitudes in wells $\mathrm{TH} 3$, TH7, and TH8.

The head in the surficial aquifer was higher than the head in the confining unit during winter and spring at all the sites except at site 9 , where a reversal lasted for several days in February.

The effects of tides are not observed in wells screened in the confining unit. The amplitude of the anticipated head change caused by tides in wells screened in the confining unit was calculated from the following equation, as given by Todd (1980):

$$
h_{x}=h_{o} e^{-x \sqrt{\frac{\pi S}{t_{o} T}}}
$$

where

$$
\begin{aligned}
h_{x}= & \text { ground-water fluctuation because of tide } \\
& \quad \text { at a distance } x, \\
h_{0}= & \text { water level in tidal body, } \\
x= & \text { distance from outcrop, } \\
S= & \text { storage coefficient of aquifer, } \\
t_{o}= & \text { tidal period, and } \\
T= & \text { transmissivity. }
\end{aligned}
$$

On the basis of this equation, water levels in wells that are closest to shore would be expected to fluctuate less than $0.01 \mathrm{ft}$ in response to the tides in the adjacent river. A fluctuation of that magnitude is lower than the resolution of the water-level recorders. Although tides probably affect water levels in the confining unit, they result in small head changes and thus have a negligible effect on ground-water flow within the confining unit.

Confined aquifer.--Seasonal variation of the water level in the confined aquifer is primarily seen as short periods of reversal of vertical ground-water flow in the summer months. This reversal is not observed in upland areas where the vertical head gradient is downward yearround, with flow from the confining unit downward into the confined aquifer (figs. 26-28). The reversal occurs in low-lying areas (figs. 24, 25, and 29), primarily because of a decline in head in the surficial aquifer and confining unit; the head in the confined aquifer changes little. The head relations observed in the low-lying areas in the summer months probably mimic the head relations in offshore areas, because the heads in the surficial aquifer and the confining unit are closest to the stage in the estuaries during the summer.

The effects of tides on water levels were observed in all the wells screened in the confined aquifer (fig. 31). It is difficult to differentiate between the hydrographs in figure 31 , because the tidal fluctuations have virtually identical patterns and are of similar magnitude in all of the wells, regardless of distance from the tidal body. 


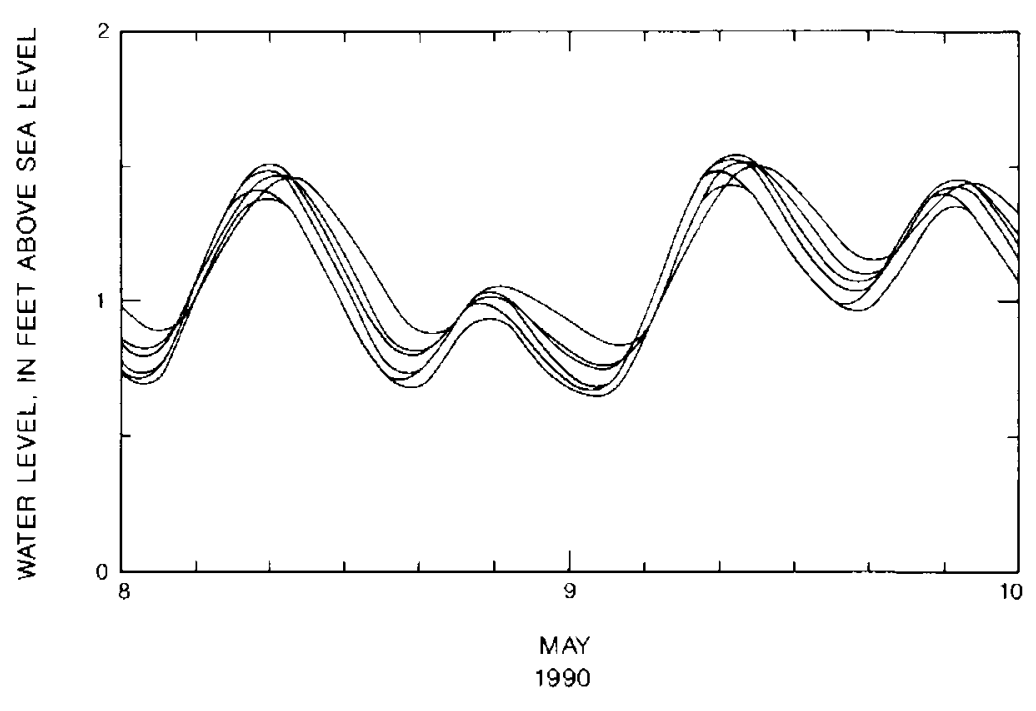

Figure 31.--Water-level altitudes in wells (JF91, 111, $41,11,31,21)$ screened in the confined aquifer. Data collected at 15 -minute intervals, May 8 to 10, 1991.

The water-level fluctuations in the wells cannot be directly compared to tide data, because the tide gage at J-Field was destroyed by ice before the water-level recorders were installed. Cyclical fluctuations of the water levels in the confined aquifer are most likely caused by tides, because they follow a twice-daily high and low cycle and there is no other known cause of the fluctuations. The seismic and geologic data indicate that no outcrop of the confined aquifer lies beneath any of the estuaries; therefore, the tidal fluctuations observed in wells screened in this unit most likely result from tidal loading. Tidal loading is when a confined aquifer is compressed by the additional weight of water present during high tide. The compression at high tide causes a rise in the water level in the confined aquifer, and the release of compression causes a subsequent drop in the water level at low tide.

Patapsco Formation.--The heads in the Patapsco Formation were lower in the drier months of the year; however, data are insufficient to determine whether this was a seasonal or tidal effect. Data also were insufficient to determine whether water levels in the Patapsco
Formation are affected by tides; however, large areas of the Patapsco Formation underlie the estuaries surrounding J-Field, and tidal loading will most likely cause water-level fluctuations similar to those in the confined aquifer in the Patapsco Formation beneath J-Field.

\section{SOIL GAS}

Analyses of the types, distribution, and relative abundance of soil-gas contaminants can aid in locating the greatest concentrations of ground water and soil contaminants. Soil-gas samples at J-Field were collected by a static technique, which yields semiquantitative analyses. The results of these analyses can be used only to determine areas of greatest soil-gas contamination and not to determine the actual concentration of contaminants in soil or ground water. The technique also is more sensitive to some compounds than others; for example, a high relative-flux value for tetrachloroethane might be 100,000 , whereas a high relative-flux value for phthalates might be only 1,000 .

Although the relative-flux value is greater for tetrachloroethane than for phthalates, the actual concentration of phthalates in ground water or soil could be greater than the concentration of tetrachloroethane. The sensitivity of the technique is variable because compounds differ in their tendency to be adsorbed by the collection material. Therefore, different compounds make different amounts of gas available for adsorption according to their volatility. Because the relative-flux values for different compounds cannot be compared, the actual ion counts are not discussed in the text of the report. The areas of greatest soil-gas contamination are described as having high relative-flux values, and the least contaminated are described as having low relative-flux values.

The organic compounds detected in soilgas samples can result from contaminated soil or contaminated ground water. It is not possible to differentiate between the sources responsible for the compounds detected with the soil-gas collectors. In this study, however, large continuous areas of soil-gas contamination were interpreted as areas of ground-water contamination and the soil-gas data were used with other 
hydrogeologic data to locate observation wells. Small isolated areas of soil-gas contamination could indicate areas where surface contaminants have not percolated downward to the groundwater system in significant quantities.

\section{Phase I}

The first phase of soil-gas sampling and analysis was conducted at the toxic-materials disposal area and white-phosphorus disposal area to assist in locating observation wells. Sampling locations were chosen to cover the area immediately surrounding the disposal pits. The pits and the open areas surrounding them are probably the primary source of contaminants.

\section{Toxic-Materials Disposal Area}

A total of 37 soil-gas collectors were used at the toxic-materials disposal area. The collectors were placed in an irregular rectangular grid pattern with a spacing of 50 to $100 \mathrm{ft}$ between collectors (fig. 32). Relative-flux maps for trichloroethylene, tetrachloroethylene, alkanes, combined hydrocarbons, and simple aromatics were drawn on the basis of the analyses. The flux distributions for trichloroethylene, tetrachloroethylene, combined hydrocarbons, and simple aromatics, which are contoured in figures $32 \mathrm{~A}, \mathrm{~B}$, $D$, and $E$, are similar. All of these compounds are found in a broad band that extends across the eastern end of the disposal pits from the marsh on the northern side to the marsh on the southern side. The alkanes appear to be concentrated primarily on the southern side of the disposal pits, where high flux values can be seen toward the edge of the sampled area (fig. 32C). The high alkane flux values to the south could represent a plume of contaminated ground water that is flowing downgradient toward a southern discharge point in the marsh.

The distribution of soil-gas contaminants at the toxic-materials disposal area could result from the downgradient flow of contaminated ground water from source areas at the pits toward discharge areas in the marsh. The map of hydraulic head in the surficial aquifer at the toxic-materials disposal area (fig. 21) shows flow directions in the surficial aquifer away from the pits, toward the marsh on both sides. A groundwater divide trends roughly northwest to southeast through the pits (fig. 21), so that the contaminants diverge into two plumes, one moving south and one north.

\section{White-Phosphorus Disposal Area}

Thirty-five soil-gas collectors were used in the area immediately surrounding the whitephosphorus disposal area. The collectors were placed in an irregular rectangular grid pattern, as shown in figure 33. Relative-flux maps were generated from analyses of the collectors for trichloroethylene, tetrachloroethylene, simple aromatics, and combined hydrocarbons (fig. 33).

The highest relative-flux values for trichloroethylene and tetrachloroethylene were measured along the shore of the Gunpowder River (figs. 33A and B). The highest flux values for simple aromatics and combined hydrocarbons were found on the northern side of the disposal pits and near the shore of the Gunpowder River (figs. 33C and D). The flux values within, and immediately adjacent to, the pits were not determined because previous work (Nemeth and others, 1983) indicated that soil in the pits was contaminated with organic solvents. It is likely that the high fluxes measured along the river and to the north of the pits are associated with two plumes of contaminated ground water. The distribution of contaminants probably results from downgradient flow of contaminated ground water from source areas at the pits toward discharge areas in the Gunpowder River. Ground-water flow in the surficial aquifer (fig. 21) is from the pits toward the Gunpowder River. It is possible that part of the western plume is located offshore, where it could be discharging into the Gunpowder River.

Two areas of isolated high flux values for all the compounds except trichloroethylene are present on the south side of the white-phosphorus disposal area (fig. 33). These elevated flux values could represent soil contamination that resulted from small spills. They also could be part of a larger plume located south of the area. 

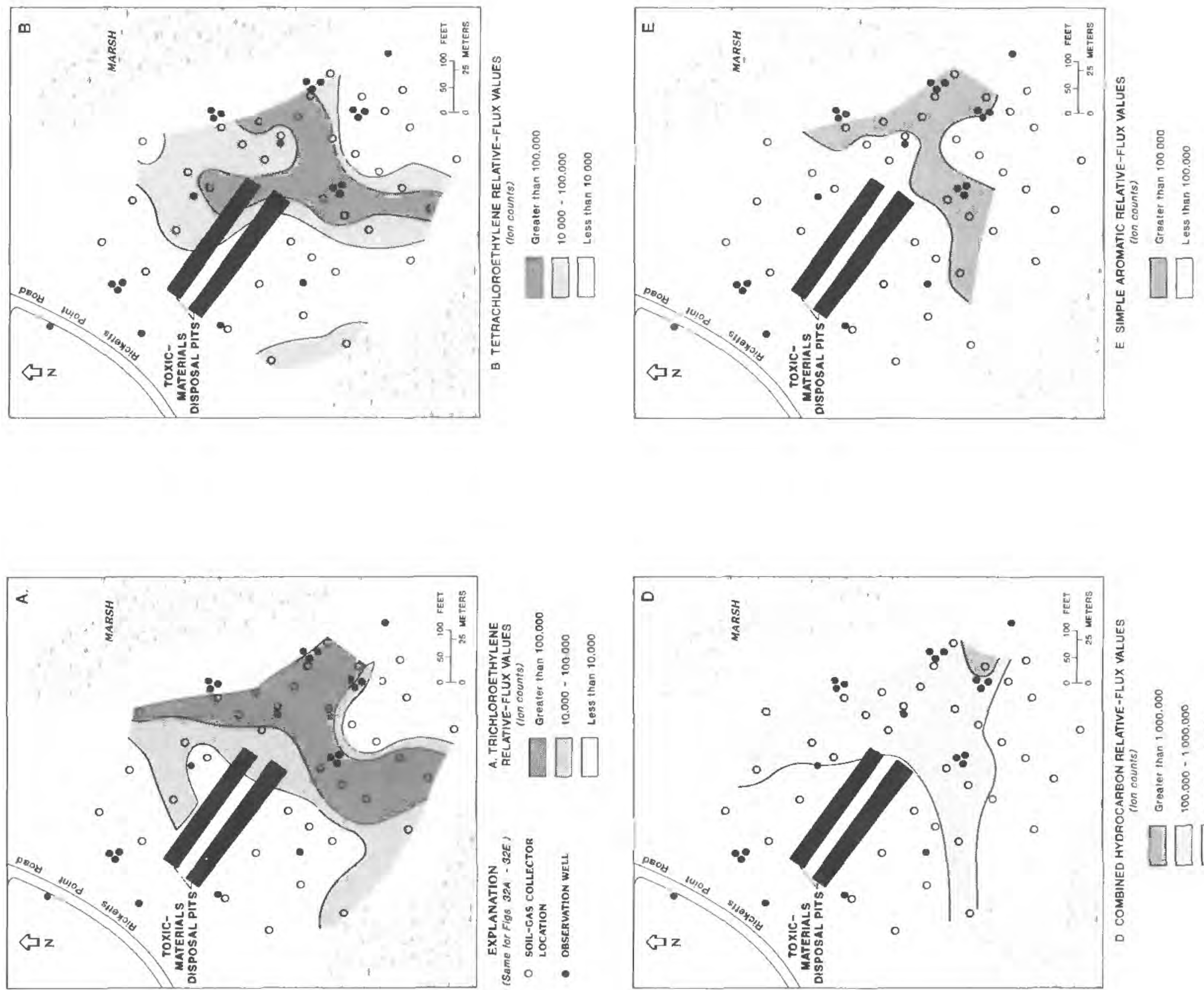

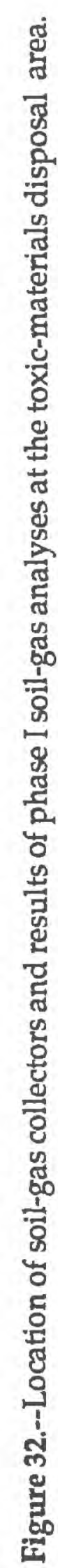



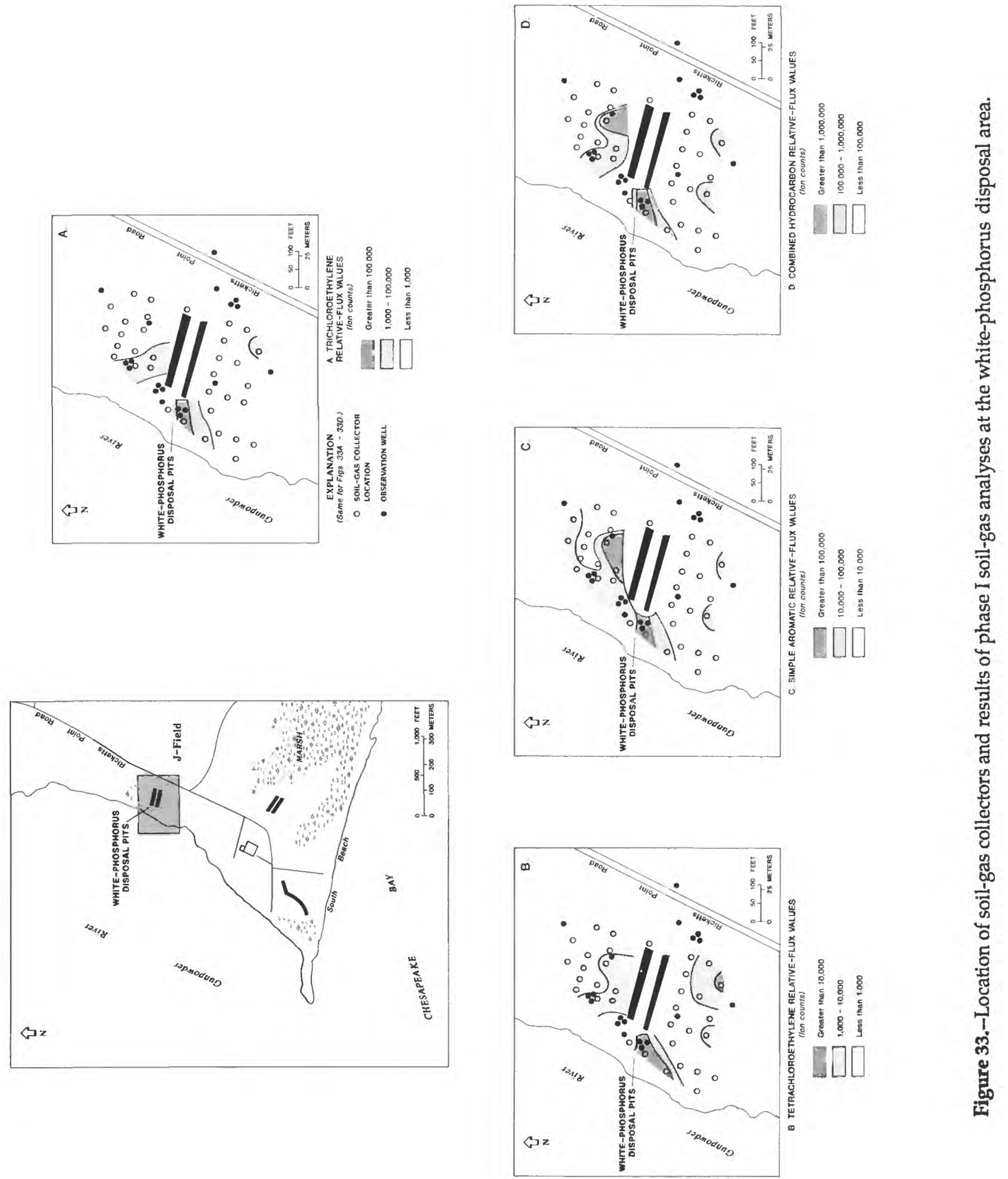
Although disposal operations were concentrated in the immediate pit area, some organic compounds could have been dumped or spilled in the vicinity.

\section{Phase II}

A second phase of soil-gas sampling was conducted to (1) determine the extent of contamination identified in the toxic-materials disposal area area; (2) look for contamination plumes at the riot-control-agent disposal area; and (3) determine if contaminated ground water is migrating beneath and possibly discharging into the Gunpowder River or Chesapeake Bay.

To meet these objectives, two grids containing a combined total of 47 soil-gas collectors were used in the woods and marshes north and south of the toxic-materials disposal area (fig. 34), and a single grid containing 12 collectors was used at the riot-control-agent disposal area (fig. 35). A line of 15 collectors also was established along the shore of the Chesapeake Bay (fig. 34). In the marsh areas and along the shore where saturated soils are present, the soil-gas collectors were placed in polyethylene bags to prevent water from contacting the charcoal element in the soilgas collector. The polyethylene bags are chemically inert with regard to this procedure and permeable to the soil gases that were examined (M.H. Hatheway, Northeast Research Institute, oral commun., 1990). The only potential difference between using the soil-gas collectors in marsh areas and in dry areas is that contaminants in surface water might be detected in areas where the collectors were submerged. Soil-gas collectors were used in polyethylene bags by Vroblesky and others (1991) to map zones of contaminated ground-water discharge in creek-bottom sediments at O-Field. Vroblesky and others (1991) found that enclosing the collectors in bags tended to slightly increase the detection potential of the samplers for benzene and chlorinated solvents.

\section{Toxic-Materials Disposal Area}

Four flux maps of the toxic-materials disposal area (fig. 34 ) were produced with the data collected from the soil-gas analyses. Relative-flux maps were drawn to show the distribution for combined dichloroethylene and trichloroethane, combined trichloroethylene and tetrachloroethylene, phthalates, and heavy aromatic hydrocarbons.

\section{Dichloroethylene and trichloroethane}

The combined dichloroethylene and trichloroethane fluxes are highest southeast of the disposal pits (fig. 34A). These high values are probably the same as those identified during the first phase of soil-gas sampling. Somewhat lower flux values are present throughout extensive areas of the marsh and probably result from discharge of contaminated ground water. The concentration of contaminants is lower in the marsh than in the ground water, because the contaminant plume becomes attenuated as it disperses and mixes with uncontaminated surface water. These values extend as far east as the location of sample collection but do not extend to the southern shore of the Bay. One high value is located in the marsh southeast of the disposal pits, and a larger area of elevated values is located to the north. These high values could represent soil or ground water that was contaminated by dumping at these locations.

\section{Trichloroethylene and tetrachloroethylene}

The trichloroethylene and tetrachloroehylene fluxes were highest east and south of the toxic-materials disposal area, and high flux values extended to the western edge of the marsh adjacent to and east of the site (fig. 34B). These values are similar to those for the combined dichloroethane and trichloroethane and probably represent a surface expression of the same ground-water contamination.

\section{Phthalates}

Elevated phthalate relative-flux values are present in the same general locations as those for the elevated chlorinated solvent values, but cover a smaller area (fig. $34 \mathrm{C}$ ). The highest flux values for the phthalates are located at the southeastern end of the disposal pits; values decreased toward the southern end of the marsh. A single 

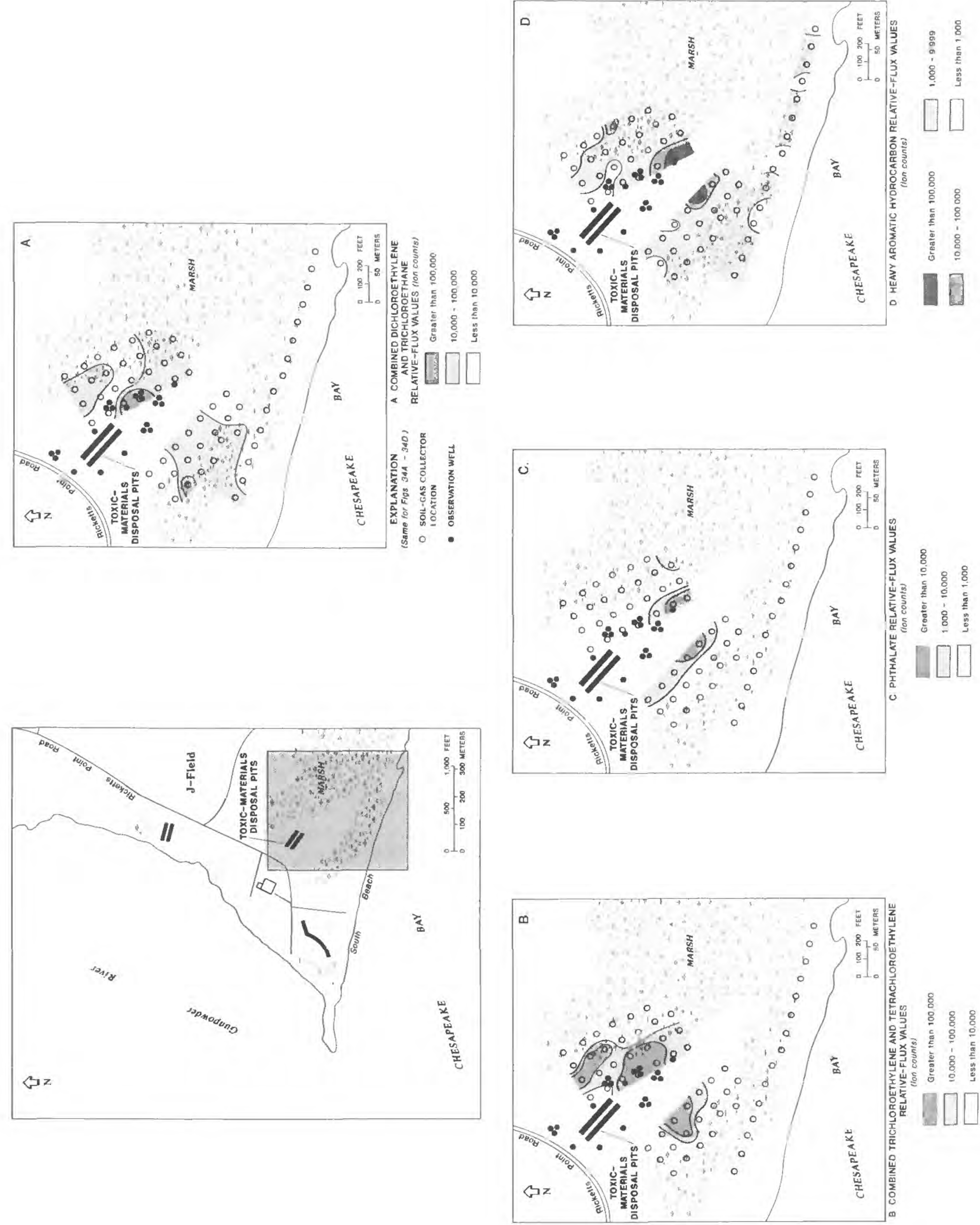

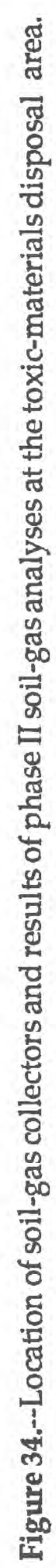




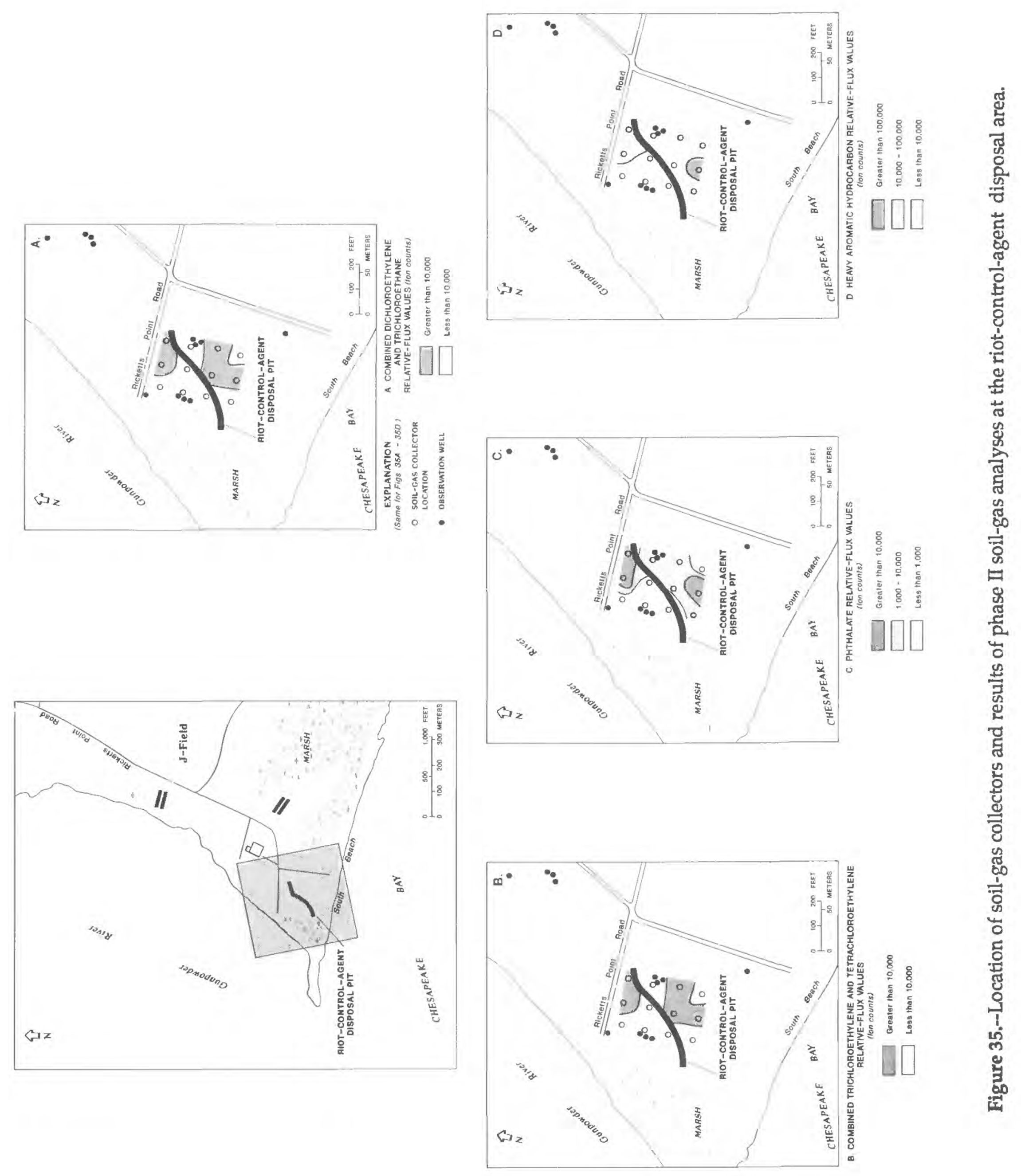


isolated high value for phthalates was measured in the South Beach area, at the extreme western end of the line of collectors along the shore. The phthalates could be associated with the highexplosive demolition work that was conducted at the southeastern end of the toxic-materials disposal area and in the South Beach area. Phthalates are a component of plastic explosives and have only been identified in soil gas at U.S. Army disposal and testing sites examined with the Petrex technique (M.H. Hatheway, Northeast Research Institute, oral commun., 1990).

\section{Heavy aromatic hydrocarbons}

The heavy aromatic hydrocarbons are the most geographically extensive contaminants identified in the vicinity of the toxic-materials disposal area from the soil-gas analyses (fig. 34D). The highest relative-flux values are located southeast of the disposal pits, and elevated fluxes are found in extensive areas of the marsh. The heavy aromatic hydrocarbons are contoured at lower flux values than are the chlorinated solvents and phthalates, because the laboratory instruments are less sensitive to the chlorinated solvents and phthalates than they are to the heavy aromatic hydrocarbons. Thus, a low hydrocarbon flux could be more significant than a low flux of the other compounds. The distribution of the hydrocarbon flux probably indicates flow of contaminated ground water downgradient from the disposal pits. The distribution of hydrocarbons in the marsh area is widespread, indicating that contaminated ground water discharges to the surface water in the marsh. Widespread distribution of heavy aromatic hydrocarbons in the marsh could result from the more rapid and complete dispersion of contaminants in surface water, as compared to ground water.

Elevated relative-flux values for heavy aromatic hydrocarbons were measured by most of the samplers located along the shore of the Chesapeake Bay, indicating that contaminated ground water flows toward the Bay. Contaminated surface water from the marsh also could be flowing slowly through the beach sediments along the shore and discharging into the Bay.

\section{Riot-Control-Agent Disposal Area}

The soil-gas contaminants at the riotcontrol-agent disposal area are concentrated in two areas, one north and one south of the pit (fig. 35). The combined dichloroethylene and trichloroethane flux was greatest on the northern and southern side of the pit (fig. 35A), as was the combined trichloroethylene and tetrachloroethyleneflux (fig. 35B). The highest flux value for the phthalates was found adjacent to Ricketts Point Road and near South Beach (fig. 35C). The heavy aromatic flux was greatest south of the pit (fig 35D).

Ground water in the surficial aquifer near the riot-control-agent disposal area generally flows from northeast to southwest (fig. 21). The expected direction of contaminant transport is from the disposal pit toward the south and southwest; however, results of the soil-gas analyses indicate that the contaminants are present primarily in two isolated areas on either side of the pit. The high fluxes found on the southern side could result from the flow of contaminated ground water downgradient from the pit area. The high fluxes to the north could be caused by contamination of the soil or, possibly, by a slight mound in the water table, which would cause ground water to flow in that direction.

\section{SUMMARY AND CONCLUSIONS}

The disposal of chemical agents, munitions, and organic chemicals at J-Field, Aberdeen Proving Ground, Md., has contaminated soil, ground water, and surface water. A 5-year study conducted by the U.S. Geological Survey, in cooperation with the U.S. Army, to investigate the types, extent, and potential migration pathways for contaminants, began in 1987 . The first phase of this investigation involved defining the hydrogeologic framework through a program of drilling exploratory boreholes, installing observation wells, measuring water levels, and determining the hydraulic properties of aquifers and confining units. Soil-gas samples were collected and analyzed to map the extent of contaminants and to aid in locating observation wells. 
A total of 7 exploratory boreholes were drilled and a network of 38 observation wells were constructed at J-Field. The deepest unit penetrated during drilling was the Patapsco Formation in the Cretaceous Potomac Group, which consists of laterally discontinuous, interbedded fine sand and clay. In this area, the Patapsco Formation is unconformably overlain by a complex of Pleistocene fluvial and estuarine sediments 40 to $160 \mathrm{ft}$ thick. The Pleistocene deposits in the study area are found in a paleochannel incised in the underlying Cretaceous sediments. The extent of the paleochannel sediments was mapped in adjacent offshore areas with marine-seismic-profiling techniques.

The Pleistocene paleochannel deposits can be divided into three distinct hydrologic units--a surficial aquifer, a confining unit, and a confined aquifer. The surficial aquifer consists of interbedded sand and clay and is under water-table conditions. The horizontal hydraulic conductivity of this unit ranges from 0.29 to $1.04 \mathrm{ft} / \mathrm{d}$, with a median of $0.69 \mathrm{ft} / \mathrm{d}$. Ground water in the surficial aquifer at J-Field flows in a horizontal direction from the uplands toward low-lying areas adjacent to marshes and estuaries. The surficial aquifer is underlain by a confining unit consisting of silty clay. The range of horizontal hydraulic conductivities for this unit is $<0.01$ to $0.20 \mathrm{ft} / \mathrm{d}$, with a median of $0.05 \mathrm{ft} / \mathrm{d}$. The head distribution and horizontal flow directions in the confining unit are similar to those in the surficial aquifer, although the horizontal head gradients are much lower. The confined aquifer consists of coarse sand and gravel mixed with clay and horizontal hydraulic conductivities range from 3.16 to $9.32 \mathrm{ft} / \mathrm{d}$. The head gradients in the confined aquifer are small and strongly affected by tides. The horizontal hydraulic conductivity of the Patapsco Formation ranges from 0.06 to $0.61 \mathrm{ft} / \mathrm{d}$. Vertical ground-water flow in the Patapsco Formation is probably upward toward discharge areas in the Chesapeake Bay.

Vertical ground-water flow in the Pleistocene deposits beneath J-Field is downward from the surficial aquifer, through the confining unit, and into the confined aquifer. In offshore areas, this relation is reversed; flow is upward from the confined aquifer, and through the confining unit and the surficial aquifer, whereupon ground water discharges into the estuaries. Only small amounts of water are likely to flow vertically through the confining unit because of its low horizontal hydraulic conductivity.

Two phases of soil-gas analyses were conducted at $\}$-Field. The first phase was used to assist in locating phase I observation wells. The following compounds were mapped: trichloroethylene, tetrachloroethylene, simple aromatic hydrocarbons, and combined hydrocarbons. At the toxic-materials disposal area, a broad band of contamination was found to extend across the downgradient end of the disposal pits, extending from the marsh on the north to the marsh on the south. This contaminant distribution indicates that two plumes of contaminated ground water are flowing toward discharge areas in the marshes. One plume is flowing to the north and the other is flowing to the south. At the whitephosphorus disposal area, two potential groundwater-contamination plumes were identified, one to the north and the other to the south of the pits. Smaller, isolated contaminated zones were identified in both areas.

The second phase of soil-gas sampling was used to choose sites for phase II well drilling and to determine the extent of the contamination identified during the first phase of soil-gas sampling. In this phase, the following compounds were mapped: combined dichloroethylene and trichloroethane, combined trichloroethylene and tetrachloroethylene, phthalates, and heavy aromatic hydrocarbons. Elevated relative-flux values for chlorinated ethylenes and ethanes were found several hundred feet into the marshes around the toxic-materials disposal area. Phthalate and heavy aromatic hydrocarbon fluxes were highest at the downgradient end of the toxic-materials disposal area, and high flux values of heavy aromatic hydrocarbons were detected throughout the adjacent marsh. The distribution of contaminants indicates that contaminated ground water discharges into the marshes on the northern and southern sides of the toxic-materials disposal area. 
Two areas of elevated soil-gas contaminants were identified at the riot-control-agent disposal area. Combined dichloroethylene and trichloroethane, combined trichloroethylene and tetrachloroethylene, and phthalate fluxes were elevated immediately north of the pit and to the south of the pit. The relative flux of heavy aromatic hydrocarbons was highest to the south of the pit and was elevated throughout the sampled area. The elevated relative-flux values to the south of the pit probably result from flow of contaminated ground water in that direction. The elevated values to the north could result from contaminants in soil.

\section{REFERENCES CITED}

Bennett, R.R., and Meyer, R.R., 1952, Geology and ground-water resources of the Baltimore area: Maryland Department of Geology, Mines and Water Resources ${ }^{1}$ Bulletin 4, $573 \mathrm{p}$.

Brenner, G.J., 1963, The spores and pollen of the Potomac Group of Maryland: Maryland Department of Geology, Mines and Water Resources Bulletin 27, 215 p.

Colman, S.M., and Mixon, R.M., 1988, The record of major Pleistocene sea-level change in a large Coastal Plain estuary, Chesapeake Bay, eastern United States: Palaeogeography, Palaeoclimatology, and Palaeoecology, v. 68, p. 99-116.

Cooper, H.H., Bredehoeft, J.D., and Papadopulos, I.S., 1967, Response of a finite-diameter well to an instantaneous charge of water: Water Resources Research, v. 3, no. 1, p. 263-269.

Hack, J.T., 1957, Submerged river system of Chesapeake Bay: Geological Society of America Bulletin, v. 68, p. 817-830.

Hansen, H.J., III, 1966, Pleistocene stratigraphy of the Salisbury area, Maryland, and its relationship to the lower Eastern Shore--A subsurface approach: Maryland Geological Survey Report of Investigations No. 2, 56 p.

1. The name of this agency was changed to the Maryland Geological Survey in June 1964.
Hughes, W.B., 1991, Application of marineseismic profiling to a ground-water contamination study, Aberdeen Proving Ground, Maryland: Ground Water Monitoring Review, v. 11, no. 1, p. 97-102.

Hurlbut, C.S., Jr., and Klein, Cornelius, 1977, Manual of mineralogy (19th ed.): New York, John Wiley and Sons, 532 p.

Hvorslev, M.J., 1951, Time lag and soil permeability in groundwater observations: Vicksburg, Miss., U.S. Army Corps of Engineers Waterways Experimental Station Bulletin No. 36, 50 p.

Kerhin, R.T, Halka, J.P., Wells, D.V., Hennessee, E.L., Blakeslee, P.J., Zoltan, Nicholas, and Cuthbertson, R.H., 1988, The surficial sediments of the Chesapeake Bay, Maryland--Physical characteristics and sediment budget: Maryland Geological Survey Report of Investigations No. 48, $82 \mathrm{p}$.

Minard, J.P., May, F.E., and Christopher, R.A., 1980, Geology of the Round Bay quadrangle, Anne Arundel County, Maryland: U.S. Geological Survey Professional Paper 1109, 30 p.

Munsell Color, 1975, Munsell soil color charts: Macbeth, a division of Kollmorgen Instruments Corporation, Baltimore, Maryland, $21 \mathrm{p}$.

Nemeth, Gary, Murphy, J.M., and Zarzycki, J.H., 1983, Environmental survey of the Edgewood Area of Aberdeen Proving Ground, Maryland: Aberdeen Proving Ground, Maryland, U.S. Army Toxic and Hazardous Materials Agency Report No. DRXTH-AS-FR-82185, 265 p.

Nemeth, Gary, 1989, RCRA facility assessment report, Edgewood Area: Aberdeen Proving Ground, Maryland, U.S. Army Toxic and Hazardous Materials Agency Project No. 39-26-0490-90, 929 p.

Oliveros, J.P. and Vroblesky, D.A., 1989, Hydrogeology of the Canal Creek Area, Aberdeen Proving Ground, Maryland: U.S. Geological Survey Water-Resources Investigations Report 89-4021, 50 p. 
Otton, E.G., and Mandle, R.J., 1984,

Hydrogeology of the upper Chesapeake Bay area, Maryland, with emphasis on aquifers in the Potomac Group: Maryland Geological Survey Report of Investigations No. 39, $62 \mathrm{p}$.

Owens, J.P., 1969, Coastal Plain rocks of Harford County, in The geology of Harford County, Maryland: Maryland Geological Survey, p. 77-103.

Princeton Aqua Science, 1984, Munitions disposal study: Aberdeen Proving Ground, Maryland, Environmental Management Office, $44 \mathrm{p}$.

Sirkin, L.A., Denny, C.S., and Rubin, Meyer, 1977, Late Pleistocene environment of the central Delmarva Peninsula, DelawareMaryland: Geological Society of America Bulletin, v. 88, p. 139-142.

Todd, D.K., 1980, Ground water hydrology (2d ed.): New York, John Wiley and Sons, 535 p.

Vroblesky, D.A., Lorah, M.M., and Trimble, S.P., 1991, Mapping zones of contaminated ground-water discharge using creek-bottom-sediment vapor samplers, Aberdeen Proving Ground, Maryland: Ground Water, v. 29, no. 1, p. 7-12.

Whitehead, D.R., 1967, Studies of full-glacial vegetation and climate in Southeastern United States, in Cushing, E.J., and Wright, H.E., Jr., eds., Pleistocene Paleoecology: New Haven, Conn., Yale University Press, p. 237-248. 
Table 8.--Lithologic logs for well-cluster and borehole sites

[Codes enclosed in parentheses refer to the Munsell Soil Color Charts (1975)]

$\begin{array}{llcllll}\text { Term } & \text { Grain size (microns): } & \text { Term } & & \text { Grain size (microns) : } & \text { Relative abundance descriptors: } \\ \mathrm{vcU}= & 1,410-2,000 & \mathrm{~mL} & = & 250-350 & \text { Abundant }>30 \% \\ \mathrm{vcL}= & 1,000-1,410 & \mathrm{fU} & = & 177-250 & \text { Common }>15 \% \text { and }<30 \% \\ \mathrm{cU}= & 710-1,000 & \mathrm{fL} & = & 125-177 & \text { Minor }>1 \% \text { and }<15 \% \\ \mathrm{cL}= & 500-710 & \mathrm{vfU} & = & 88-125 & \text { Trace }<1 \% \\ \mathrm{mU}= & 350-500 & \mathrm{vfL} & =62-88 & \end{array}$

\begin{tabular}{|c|c|c|}
\hline Lithology & $\begin{array}{l}\text { Depth } \\
\text { (feet) }\end{array}$ & $\begin{array}{l}\text { Thickness } \\
\text { (feet) }\end{array}$ \\
\hline
\end{tabular}

\section{Exploratory Borehole 1}

Sand, quartz, fine (mU-fU), brown (10 YR 5/3); shell fragments; abrupt boundary.

Sand, quartz, fine (mU-fU), light yellowish-brown (10 YR 6/9); silt coatings on clay surfaces; gradual boundary.

Sand, quartz, fine (mU-fU), yellowish-brown (10 YR 5/6); clay common.

Sand, quartz, medium (mL), dark yellowish-brown (10 YR 4/6); mica, trace.

Sand, quartz, fine (fL), yellowish-brown (10 YR 5/4); silt, trace; abrupt boundary.

\section{5}

Sand, quartz, fine (fL), yellowish-brown (10 YR 5/4); silt, common, laminated; gradual boundary.

Sand, quartz, medium (mL), light gray (10 YR 6/2) and yellowish-brown (10 YR 5/8); clay interbedded, common; mica, trace; gradual boundary.

Sand, quartz, medium (mU-mL), light gray (10 YR 7/1) and yellowish-brown (10 YR 5/8); mica, common; abrupt boundary.

Sand, quartz, fine ( $\mathrm{fL})$, dark gray (5 Y 4/1), massive; clay abundant.

Sand, quartz, medium (mU), dark gray (5 Y 4/1), massive; clay abundant.

No sample.

Clay, dark gray (5 Y 4/1); silt, common.

Clay, dark gray ( 5 Y $4 / 1)$; silt, common.

Clay, dark gray $(5 Y 4 / 1)$; silt, common; contains shell fragments.

Clay, dark gray (5 Y 4/1); silt, common.

Clay, dark gray (5 Y 4/1); silt, common, mixed with sand, quartz, medium to coarse (mU-cU, cL) and pebbles up to $5.0 \mathrm{~cm}$.

Gravel, and sand, quartz, very coarse (vcU-vcL), pebbles up to $5.0 \mathrm{~cm}$, subangular, subrounded; mica, minor.

Gravel, and sand, quartz, very coarse (vcU-vcL), pebbles up to $1.0 \mathrm{~cm}$, subangular, subrounded; mica, minor.

Gravel, and sand, quartz, very coarse (vcU), pebbles up to $1.0 \mathrm{~cm}$, subangular, subrounded; pebbles, quartz, and granitic conglomerate; mica, trace.

Gravel, and sand, quartz, very coarse (vcU), pebbles up to $1.0 \mathrm{~cm}$, subangular, subrounded; pebbles, quartz, and granitic conglomerate; mica, trace.

Sand, quartz, very coarse (vcU-vcL) to medium ( $m U$ ); shell fragments, minor.

Sand, quartz, very coarse (vcU-vcL) to medium (mU); sand, quartz, medium (mL), subrounded; clay, trace.

Sand, quartz, very coarse (vcU-vcL) to medium (mU); clay, light gray (10 YR 7/2).

Sand, quartz, very coarse (vcU-vcL) to medium (mU); clay, reddish-brown (5 YR $5 / 3$ ).

Sand, quartz, very coarse (vcU-vcL) to medium (mU); clay, red, common.

Sand, quartz, very coarse ( $v c U-v c L$ ) to medium (mU); clay, light gray (10 YR 7/1), minor. Sand, quartz, very coarse ( $v c U-v c L$ ) to medium (mU); clay, light gray (10 YR 7/1), common No sample.

Sand, quartz; clay, abundant, light gray (10 YR 7/1).

No sample.
1.0

2.3

3.5 
Table 8.--Lithologic logs for well-cluster and borehole sites

[Codes enclosed in parentheses refer to the Munsell Soil Color Charts (1975)]

\begin{tabular}{|c|c|c|c|c|c|}
\hline Term & & Grain size (microns) : & Term & Grain size (microns) & Relative abundance descriptors: \\
\hline $\mathbf{v c U}$ & $=$ & $1,410-2,000$ & $\mathrm{~mL}$ & $250-350$ & Abundant $>30 \%$ \\
\hline$v c L$ & $=$ & $1,000-1,410$ & $\mathrm{fU}$ & $177-250$ & Common $>15 \%$ and $<30 \%$ \\
\hline $\mathrm{cU}$ & $=$ & $710-1,000$ & $\mathrm{fL}$ & $125-177$ & Minor $>1 \%$ and $<15 \%$ \\
\hline $\mathrm{cL}$ & $=$ & $500-710$ & vfU & $88-125$ & Trace $<1 \%$ \\
\hline $\mathbf{m U}$ & $=$ & $350-500$ & vfL & $62-88$ & \\
\hline
\end{tabular}

\begin{tabular}{lll}
\hline Lithology & $\begin{array}{l}\text { Depth } \\
\text { (feet) }\end{array}$ & $\begin{array}{l}\text { Thickness } \\
\text { (feet) }\end{array}$ \\
\hline
\end{tabular}

Exploratory Borehole 1-Continued

Clay, medium dark gray (N4); silt, common; mica, trace.

Sand, quartz; shell and rock fragments, coarse (cU-vcU), medium gray (N5).

Sand, quartz; shell and rock fragments, medium (mU), light gray (N7); mica, trace.

270.0

10.0

Sand, quartz; mica and rock fragments, very coarse (vcU), well sorted, subrounded; clay, dark yellowish-brown (10 YR 4/2).

280.0

10.0

Sand, quartz; mica and rock fragments, very coarse (vcU), well sorted, subrounded; clay, dark yellowish-brown (10 YR 4/2).

Clay, moderate reddish-brown (10 YR 4/6).

Clay, light yellowish-brown (10 YR 6/2).

305.0

Clay, light yellowish-brown (10 YR 6/2). 
Table 8.--Lithologic logs for well-cluster and borehole sites

[Codes enclosed in parentheses refer to the Munsell Soil Color Charts (1975)]

$\begin{array}{llllll}\text { Term } & \text { Grain size (microns) : } & \text { Term } & & \text { Grain size (microns) : } & \text { Relative abundance descriptors: } \\ \mathrm{vcU}= & 1,410-2,000 & \mathrm{~mL} & = & 250-350 & \text { Abundan }>30 \% \\ \mathrm{vcL}= & 1,000-1,410 & \mathrm{fU} & = & 177-250 & \text { Common }>15 \% \text { and }<30 \% \\ \mathrm{cU}= & 710-1,000 & \mathrm{fL} & = & 125-177 & \text { Minor }>1 \% \text { and }<15 \% \\ \mathrm{cL}= & 500-710 & \text { vfU } & = & 88-125 & \text { Trace }<1 \% \\ \mathrm{mU}= & 350-500 & \mathrm{vfL} & =62-88 & \end{array}$

\begin{tabular}{l} 
Lithology \\
\hline Exploratory Borehole 2
\end{tabular}

Sand, quartz, fine (fU), pale brown (10 YR 6/3); silt, common; gradual boundary.

Sand, quartz, fine (fU), dark yellowish-brown (10 YR 4/4); clear boundary.

Depth

(feet)
Thickness

(feet)

Sand, quartz, medium (mU), dark yellowish-brown (10 YR 4/4); wood fragments; silt, common; clear boundary.

Sand, quartz, fine (fU), strong brown (7.5 YR 4/6); clay, common.

Sand, quartz, medium (mU-mL), dark yellowish-brown (10 YR 4/6).

Silt, yellowish-red (5 YR 5/6); mottles of sand, common, yellowish-brown (10 YR 5/6).

Sand, quartz, very fine (vfU), yellowish-brown (10 YR 5/4); mottled with strong brown (7.5 YR 5/6); residual soil structure.

Clay, light gray (N7); mottled with clay, strong brown (7.5 YR 5/8); sand, quartz, medium $(\mathrm{mU})$, common.

Clay, massive, dark gray (5 Y 4/1); very hard.

No sample.

$\begin{array}{rr}0.6 & 0.6 \\ 1.0 & .4 \\ & \\ 1.5 & .5 \\ 2.7 & 1.2 \\ 3.5 & .8 \\ & \\ 4.3 & .8 \\ 6.7 & 2.4 \\ & \\ 7.3 & .6 \\ & \\ 8.3 & 1.0 \\ 10.0 & 1.7\end{array}$

Clay, silty, light gray (5 Y 6/1); mottles, light yellowish-brown (10 YR 5/6); centers

of mottles are coarser grained; sand medium $(\mathrm{mL})$, clear boundary.

Clay, dark gray (5 Y 4/1); silt, minor; gradual boundary.

Sand, quartz, fine (fU-fL); clay, minor; mica, minor.

$15.5 \quad 5.5$

No sample.

$16.5 \quad 1.0$

$19.0 \quad 2.5$

Clay, coarse sand, some pebbles.

100.0

Gravel.

Clay, light gray, very soft.

120.0

20.0

Clay, gray and red.

No sample.

Clay, reddish-brown; shell fragments, minor.

Clay, white; shell fragments, abundant. 
Table 8.--Lithologic logs for well-cluster and borehole sites

[Codes enclosed in parentheses refer to the Munsell Soil Color Charts (1975)]

$\begin{array}{llllll}\text { Term } & \text { Grain size (microns) : } & \text { Term } & & \text { Grain size (microns) : } & \text { Relative abundance descriptors: } \\ \mathrm{vcU}= & 1,410-2,000 & \mathrm{~mL} & = & 250-350 & \text { Abundan }>30 \% \\ \mathrm{vcL}= & 1,000-1,410 & \mathrm{fU} & = & 177-250 & \text { Common }>15 \% \text { and }<30 \% \\ \mathrm{cU}= & 710-1,000 & \mathrm{fL} & = & 125-177 & \text { Minor }>1 \% \text { and }<15 \% \\ \mathrm{cL}= & 500-710 & \mathrm{vfU} & = & 88-125 & \text { Trace }<1 \% \\ \mathrm{mU}= & 350-500 & \mathrm{vfL} & = & 62-88 & \end{array}$

$\begin{array}{lll}\text { L.ithology } & \begin{array}{l}\text { Depth } \\ \text { (feet) }\end{array} & \begin{array}{l}\text { Thickness } \\ \text { (feet) }\end{array}\end{array}$

\section{Exploratory Borehole 3}

Silt, brown (10 YR 5/3); organic zone at top; shell fragments, trace; clear boundary.

Silt, light gray (10 YR 7/2); gradual boundary.

Sand, quartz, very fine (vfU), yellowish-brown (10 YR 5/6); clay, common; gradual boundary.

Sand, quartz, fine (fU), light gray ( 2.5 Y $7 / 2$ ); mica, common; abrupt boundary.

Sand, quartz, fine (fU), mixed light olive gray $(5$ Y $6 / 2)$ and yellowish-brown (10 YR 5/6).

$0.5 \quad 0.5$

No sample.

Sand, quartz, medium (mU), brown (10 YR 5/3) and yellowish-brown (10 YR 5/6); abrupt boundary.

Sand, quartz, very fine (vfU), dark gray ( 5 Y $4 / 1$ ); mica, common; abrupt boundary.

Sand, quartz, very fine (vfU), light gray (5 Y $6 / 1)$; mica, common.

Silt, dark gray (5 Y 4/1); mica, abundant; clay common.

Silt, dark gray ( 5 Y 4/1); clay, common.

Silt, dark gray (N4); mica, abundant; clay, common; organic material, trace; slight trace of bedding (2.0-3.0 $\mathrm{mm}$ thick).

No sample.

Silt, dark gray (N4); sand, quartz and rock fragments, very coarse (vcU)vcl.) with some pebbles $(>1.0 \mathrm{~cm})$, subrounded; clay, minor; mica, trace.

Sand, quartz, gneiss, quartz sandstone, rock fragments, and chert, very coarse (vcU-vcL.) with some pebbles $(>1.5 \mathrm{~cm})$, subangular.

Gravel, quartz, granite, quartz sandstone, chert, and rock fragments, subangular to subrounded; poorly sorted.

Sand, quartz, and rock fragments, coarse (cU-cL), rounded to subrounded, moderately sorted; clay, light brownish-gray (10 YR 6/2); mica, abundant.

No sample.

Clay, light brownish-gray (10 YR 6/2); sand, quartz and rock fragments, coarse (cU), subrounded to subangular; mica, abundant.

Sand, quartz, medium (mU), light gray $(5 Y 7 / 2)$, rounded, well sorted; mica, trace; several quartz sandstone cobbles ( $>3.5 \mathrm{~cm}$ ) coated in dark gray (5 Y 4/1) clay.

No sample.

Sand, quartz and rock fragments, coarse (cU-CL), subrounded to subangular; clay, gray (5 YR 5/1); shell fragments and organic material, trace; mica, trace.

Sand, quartz and rock fragments, coarse (vcL.), subrounded to subangular; clay, white (10 YR 8/1) and red (10 R 5/8); shell fragments, trace.

Sand, quartz and rock fragments, coarse (vcL), subangular; clay, very pale brown 
Table 8.--Lithologic logs for well-cluster and borehole sites

[Codes enclosed in parentheses refer to the Munsell Soil Color Charts (1975)]

\begin{tabular}{|c|c|c|c|c|c|}
\hline Term & & Grain size (microns) : & Term & Grain size (microns) : & Relative abundance descriptors: \\
\hline $\mathbf{v c U}$ & $=$ & $1,410-2,000$ & $\mathrm{~mL}$ & $250-350$ & Abundant $>30 \%$ \\
\hline $\mathrm{vcL}$ & $=$ & $1,000-1,410$ & fu & $177-250$ & Common $>15 \%$ and $<30 \%$ \\
\hline $\mathrm{cU}$ & $=$ & $710-1,000$ & $\mathrm{fL}$ & $125-177$ & Minor $>1 \%$ and $<15 \%$ \\
\hline $\mathrm{cL}$ & $=$ & $500-710$ & vfU & $88-125$ & Trace $<1 \%$ \\
\hline $\mathrm{mU}$ & $=$ & $350-500$ & vfL & $62-88$ & \\
\hline
\end{tabular}

\begin{tabular}{|c|c|c|}
\hline Lithology & $\begin{array}{l}\text { Depth } \\
\text { (feet) }\end{array}$ & $\begin{array}{l}\text { Thickness } \\
\text { (feet) }\end{array}$ \\
\hline
\end{tabular}

\section{Exploratory Borehole 4}

Sand, quartz, very fine (vfU), yellowish brown (10 YR 5/4); silt, common; clear boundary.

Sand, quartz, medium (mL), light gray (10 YR 6/1) with common yellowish brown (10 YR 5/6) mottles; clay, abundant; clear boundary.

Sand, quartz, fine (fL), yellowish brown (10 YR 5/6) with a few light gray mottles (12 YR 6/1); clay, trace; gradual boundary.

Sand, quartz, medium (mU), light gray (10 YR 7/1); with laminations 0.5-1.0 mm thick, yellowish-brown (10 YR 5/6); clay, minor; mica, trace; clear boundary.

Sand, quartz, medium (mU to $\mathrm{mL}$ ), pale brown (10 YR 6/3); mica, trace; clear boundary.

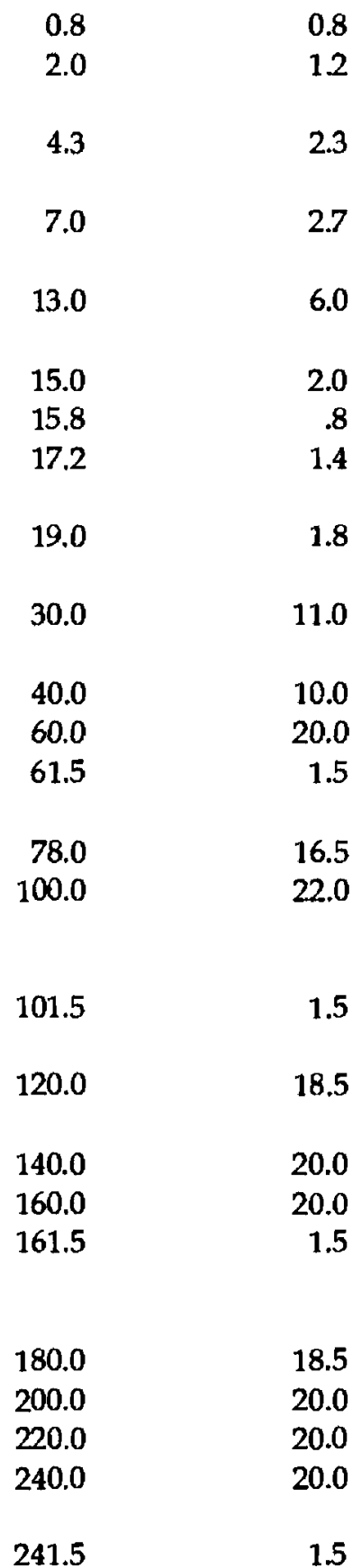

Sand, quartz, medium ( $\mathrm{mU}$ to $\mathrm{mL}$ ), brownish-yellow (10 YR 6/6); mica, trace; clear boundary.

Sand, quartz, coarse $(\mathrm{cL})$ to medium $(\mathrm{mU})$, reddish-yellow $(7.5 \mathrm{YR} 7 / 8)$, subangular; clear boundary.

Sand, quartz, very fine (vfU), light gray $(10 Y R 7 / 1)$ with reddish-yellow $(7.5 Y R 7 / 8)$ laminations (0.5-1.0 mm thick); clear boundary.

Sand, quartz, very fine (vfU), dark gray (5 Y 4/1); mica, common; thick bedding (12-25 mm thick); organic material common in discrete beds.

No sample.

Clay, dark gray (5Y 4/1); silt common.

Clay, dark greenish-gray (5 GY 4/1); silt, common; shell fragments, minor.

Clay, dark greenish-gray (5 GY 4/1); sand, quartz, medium (mL), subrounded; shell fragments, minor; faint laminations $(2.0-3.0 \mathrm{~mm}$ thick).

Clay, dark greenish-gray ( 5 GY 4/1); silt, common.

Sand, quartz and rock fragments, coarse and very coarse (cL to vcU), smaller grains are angular, larger grains are subrounded.

Sand, quartz, medium ( $\mathrm{mU}$ and $\mathrm{cL}$ ), gray (5 Y 5/1); abundant red and gray sandstone cobbles $(2.0-4.0 \mathrm{~cm}$ in diameter).

Sand, and gravel, quartz, coarse (cL), reddish-yellow and clear, subrounded to well rounded; gravel (up to $2.0 \mathrm{~cm}$ in size); rock fragments of green and red sands tone and foliated granite.

Clay, light gray (10 YR 7/1); sand, coarse (cL), as above.

Clay, light gray (10 YR 7/1) and pale red (10 YR 6/3).

Clay, mottled dark red (2.5 YR 3/6), pale red (10 YR 6/3), gray (10 YR 6/1) and light olive brown ( 2.5 Y $5 / 6)$; very fine bedding.

Clay, pale red (2.5 YR 6/2), silt, minor, content increases with depth.

Clay, light gray (10 YR 7/1) and gray (10 YR 6/1); soft.

No sample.

Sand, pale yellow (c $Y 7 / 3$ ), fine (fL); clay, common, light reddish-brown (5 YR 6/3) and dark gray (N4).

Sand, quartz, fine (fU and fL), rounded, gray (5 Y 6/1); clay, very dark gray (N3). 
Table 8.--Lithologic logs for well-cluster and borehole sites

[Codes enclosed in parentheses refer to the Munsell Soil Color Charts (1975)]

$\begin{array}{llcllll}\text { Term } & \text { Grain size (microns) : } & \text { Term } & & \text { Grain size (microns) : } & \text { Relative abundance descriptors: } \\ \mathrm{vcU}= & 1,410-2,000 & \mathrm{~mL} & = & 250-350 & \text { Abundan }>30 \% \\ \mathrm{vcL}= & 1,000-1,410 & \mathrm{fU} & = & 177-250 & \text { Common }>15 \% \text { and }<30 \% \\ \mathrm{cU}= & 710-1,000 & \mathrm{fL} & = & 125-177 & \text { Minor }>1 \% \text { and }<15 \% \\ \mathrm{cL}= & 500-710 & \mathrm{vfU} & = & 88-125 & \text { Trace }<1 \% \\ \mathrm{mU}= & 350-500 & \mathrm{vfL} & = & 62-88 & \end{array}$

\begin{tabular}{lll} 
Lithology & Depth & \multicolumn{1}{c}{ Thickness } \\
(feet) & (feet)
\end{tabular}

\section{Exploratory Borehole 5}

Sand, quartz, fine (fU), very pale brown (10 YR 7/4); silt, common; soil 0.5 zone; clear boundary.

Sand, quartz, medium (mL), strong brown (7.5 YR 5/6); clay, common; gradual boundary.

Sand, quartz, medium ( $\mathrm{mL}$ and $\mathrm{mU}$ ), subrounded, light brownish-gray $(10 \mathrm{YR} 6 / 2)$ and yellowishbrown (10 YR 5/8); mica, trace; clear boundary.

Sand, quartz, fine (fU), rounded, brown (7.5YR 4/4).

Sand, quartz, fine (fU), rounded brown (7.5 YR 4/4) with brownish gray $(10$ YR 6/2) and yellowish-brown (10 YR 5/8) laminations $5.0-6.0 \mathrm{~cm}$ thick; clear boundary.

Sand, quartz, fine (fU), dark gray (5Y 4/ 1); clay, minor; clear boundary.

Sand, quartz, medium ( $\mathrm{mU}$ ), rounded; clay, minor; mica, trace.

Clay, dark gray (5 Y 4/1), massive; organic material, minor.

Sand, quartz, medium (mU), dark gray (5 Y 4/1); mica, minor.

Sand, quartz, very fine (vfU), olive gray $(5 Y 3 / 2)$; silt, common.

Clay, olive gray ( 5 Y $3 / 2)$; mica, minor; silt, common.

Sand, very fine (vfU), dark greenish-gray ( $5 \mathrm{GY} 4 / 1$ ); silt, common; mica, minor; shell fragments, minor.

Silt, olive gray (5Y $3 / 2)$; mica, minor; shell fragments, abundant; thin bedding.

Silt, very fine (vfU), olive gray ( 5 Y $3 / 2$ ); sand, quartz, coarse (vcU), subangular; mica, minor; shell fragments, abundant.

Sand, quartz and rock fragments, very coarse (vcL. and vcU), subrounded; shell fragments, abundant; mica, trace.

Sand, quartz, coarse and medium ( $c U$ and $\mathrm{mL}$ ), rounded, very dark grayish brown (10 YR 3/2); pebbles $(1.0-2.0 \mathrm{~cm})$, rounded, minor; clay, interbedded.

Sand, quartz and rock fragments, rounded, coarse (vcL); pebbles, $1.5 \mathrm{~cm}$, common; shell fragments, common.

Gravel, quartz, and rock fragments, very coarse, subangular; shell fragments, minor; mica, trace.

Clay, white (10 YR 8/2); sand, quartz and rock fragments, coarse ( $\mathrm{C}$ to vcL), subrounded; mica, minor; shell fragments, minor.

Sand, quartz, medium (mU to $\mathrm{mL}$ ), well rounded, well sorted, light gray (10 YR 7/2); clay, minor.

$\begin{array}{ll}0.5 & 0.5 \\ 3.0 & 2.5 \\ 9.0 & 6.0 \\ 11.0 & 2.0 \\ 13.0 & 2.0\end{array}$

Clay, mottled reddish brown (5 YR 4/3) and white (10 YR 8/2); sand, quartz and rock fragments, coarse (vcL), subangular.

Clay, dark reddish-brown (5 YR 3/3); mica, minor.

Clay, dark reddish-gray (5YR 4/2); sand, quartz, and rock fragments, coarse (cU to vcL).

Clay, dark gray (5 YR 4/1); faint laminations, some are light gray (N7); silt, minor.

Clay, gray (10 YR 5/2); silt, minor; sand, quartz, medium (mU), subrounded, minor.

Clay, light brownish gray (10 YR 6/2); mixed with sand, quartz, medium (mL), subrounded, common. Clay, light gray (10YR 7/1); mixed with sand, quartz, fine (fU), subrounded, common. 
Table 8.--Lithologic logs for well-cluster and borehole sites

[Codes enclosed in parentheses refer to the Munsell Soil Color Charts (1975)]

$\begin{array}{llllll}\text { Term } & \text { Grain size (microns) : } & \text { Term } & \text { Grain size (microns) : } & \text { Relative abundance descriptors: } \\ \mathrm{vcU}= & 1,410-2,000 & \mathrm{~mL} & = & 250-350 & \text { Abundant }>30 \% \\ \mathrm{vcL}= & 1,000-1,410 & \mathrm{fU} & = & 177-250 & \text { Common }>15 \% \text { and }<30 \% \\ \mathrm{cU}= & 710-1,000 & \mathrm{fL} & = & 125-177 & \text { Minor }>1 \% \text { and }<15 \% \\ \mathrm{cL}= & 500-710 & \text { vfU }= & 88-125 & \text { Trace }<1 \% \\ \mathrm{mU}= & 350-500 & \text { vfL } & =62-88 & \end{array}$

\begin{tabular}{lll}
\hline Lithology & $\begin{array}{l}\text { Depth } \\
\text { (feet) }\end{array}$ & $\begin{array}{l}\text { Thickness } \\
\text { (feet) }\end{array}$ \\
\hline
\end{tabular}

Exploratory Borehole 6

\section{Well JF1}

Soil, sand, quartz, fine (fL); silt and clay, minor; pebbles, quartz, 1.0-2.0 cm, rounded, trace; dark brown (10 YR 4/3).

Sand, quartz, medium and fine (mU to fU), subangular, brownish-yellow (10 YR 6/6); silt, minor; gradual boundary.

Sand, quartz, medium and fine (mU to fU), subangular, mottled brownish-yellow (10 YR 6/6) and light brownish-gray (2.5 YR 6/2); silt, minor; abrupt boundary.

Clay, sand, quartz, fine ( $\mathrm{fL}$ ), gray (N5); peat, trace; clear boundary.

Sand, quart $z$, medium ( $\mathrm{mL}$ ), subrounded; silt, abundant; gradual boundary.

\begin{tabular}{rr}
1.2 & 1.2 \\
4.0 & 2.8 \\
4.4 & .4 \\
4.5 & .1 \\
5.8 & 1.3 \\
9.0 & 3.2 \\
18.0 & 9.0 \\
20.0 & 2.0 \\
40.0 & 20.0 \\
& \\
60.0 & 20.0 \\
& \\
80.0 & 20.0 \\
82.0 & 2.0 \\
& \\
147.0 & 65.0 \\
& \\
162.0 & 15.0 \\
182.0 & 20.0 \\
& \\
& \\
184.0 & 2.0 \\
202.0 & 20.0 \\
208.0 & 6.0 \\
242.0 & 34.0 \\
277.0 & 35.0 \\
304.0 & 27.0 \\
& \\
\hline
\end{tabular}

Sand, quartz, medium and fine (mU and $\mathrm{fU})$, mottled broownish-yellow $(10 \mathrm{YR} 6 / 6)$ and light brownish-gray ( 2.5 Y 6/2); bedding $2.0-3.0 \mathrm{~cm}$ thick.

Sand, quartz, medium (mL), subrounded, light brownish-gray (2.5 Y 6/2).

No sample.

Sand, quartz, rounded, coarse (cU to $\mathrm{cL}$ ); gravel, pebbles up to $1.0 \mathrm{~cm}$ diameter; silt, common; clay, gray (5 Y 5/1), minor.

Clay, dark gray ( 5 Y 4/1); bivalve shell fragments, abundant from 55.0-60.0 feet; silt, common.

Clay, dark gray (5 Y 4/1); silt common; wood fragments, minor; bivalve shell fragments, common.

Clay, dark gray (5 Y 4/1), massive; silt, common; bivalve shell fragments, minor; wood fragments, minor; sand, very fine (vfL), minor.

Clay, dark gray ( 5 Y 4/1); silt common; shell fragments, minor; organic material, minor; sand, minor.

Sand, quartz, very coarse ( $\mathrm{vcU}$ and $\mathrm{vcL}$ ), rounded and subrounded, grains are clear and golden; rock fragments of sandstone and granite (vcU), common.

Sand, quartz, very coarse ( $v c U$ and $v c L$ ), rounded; gravel consisting of rock fragments of sandstone, shale, metamorphic gneiss (up to $2.0 \mathrm{~cm}$ diameter) common; clay, dark gray (5 Y 4/1) and white (10 YR 8/1).

Sand, quartz, medium (mL), rounded, light brownish-gray (10 YR 6/2), very clear.

No sample.

Clay, light gray (10 YR 7/1); silt, common.

6.0
34.0

Clay, light gray (10 YR 7/1); silt, common; mixed with sand, quartz, medium (mL), rounded.

35.0

No sample. 
Table 8.--Lithologic logs for well-cluster and borehole sites

[Codes enclosed in parentheses refer to the Munsell Soil Color Charts (1975)]

$\begin{array}{lcclcl}\text { Term } & \text { Grain size (microns) : } & \text { Term } & \text { Grain size (microns) : } & \text { Relative abundance descriptors: } \\ \mathrm{vcU}= & 1,410-2,000 & \mathrm{~mL} & = & 250-350 & \text { Abundant }>30 \% \\ \mathrm{vcL}= & 1,000-1,410 & \mathrm{fU} & = & 177-250 & \text { Common }>15 \% \text { and }<30 \% \\ \mathrm{cU}= & 710-1,000 & \mathrm{fL} & = & 125-177 & \text { Minor }>1 \% \text { and }<15 \% \\ \mathrm{cL}= & 500-710 & \text { vfU } & = & 88-125 & \text { Trace }<1 \% \\ \mathrm{mU}= & 350-500 & \text { vfL } & =62-88 & \end{array}$

$\begin{array}{lll}\text { Lithology } & \text { Depth } & \text { Thickness } \\ \text { (feet) } & \text { (feet) }\end{array}$

Exploratory Borehole 7

Soil, organic soil zone, sandy loam, dark brown (10 YR 3/3).

Sand, quartz, medium (mU), light yellowish brown (10 YR 6/4); clay, common; gradual boundary.

Sand, quartz, medium ( $\mathrm{mU}$ ), light yellowish-brown (10 YR 5/6), gradual boundary.

Sand, quartz, fine (fL), mottled, strong brown (7.5 YR 5/6), clear boundary.

Sand, quartz, medium (mU), mottled, reddish-brown (10 YR 6/8), yellowish-red (5 YR 4/6) and yellowish-brown (10 YR 5/4)

Sand, quartz, medium ( $\mathrm{mL}$ ), light gray (10 YR 6/1); finely interbedded clay; beds $2.0-3.0 \mathrm{~cm}$ thick; clear boundary.

Sand, quartz, medium (mL), mottled, light gray (10 YR 7/1) and brownish-yellow (10 YR 6/6), cobble 4.0 in. diameter at 9.0 feet, rounded, quartz; abrupt boundary.

Sand, quartz, fine to very fine ( $\mathrm{fL}$ to $\mathrm{vfU}$ ), dark gray (N9); coarsens upwards; fine bedding; gradual boundary.

Clay, dark gray (N4), finely bedded; silt, common; abrupt boundary.

Sand, quartz, medium (mL), dark gray (N4).

$\begin{array}{rr}0.4 & 0.4 \\ 1.0 & .6 \\ 2.4 & 1.4 \\ 4.0 & 1.6 \\ 5.4 & 1.4 \\ & \\ 7.6 & 2.2 \\ & \\ 12.0 & 4.4 \\ & \\ 16.0 & 4.0 \\ & \\ 17.6 & 1.6 \\ 19.0 & 1.4 \\ & \\ 30.0 & 21.0 \\ 40.0 & 10.0 \\ 78.0 & 38.0 \\ 80.0 & 2.0 \\ & \\ 100.0 & 20.0\end{array}$

Sand, quartz, very fine (vfU); silt, abundant.

Sand, quartz, very fine (vfU); silt, abundant.

Clay, dark gray (5 Y 4/1), abundant shell fragments; silt, common.

Gravel, well rounded; sand, coarse (cU) to $1.0 \mathrm{~cm}$ size material, granitic and metamorphic rock fragments.

Gravel, well rounded; sand, coarse (cU) to $1.0 \mathrm{~cm}$ size material, granitic and metamorphic rock fragments.

Gravel well rounded; sand, coarse ( $\mathrm{CU}$ ) to $1.0 \mathrm{~cm}$ size material, granitic and metamorphic rock fragments; clay, very dark gray $(5 Y 3 / 1)$ and dark reddish-gray $(10 \mathrm{R} 3 / 1)$.

Clay, dark reddish-gray $(10 \mathrm{R} 3 / 1)$, very thinly laminated.

Clay, as above.

Clay, olive yellow (2.5 Y 6/8); sand quartz, very fine (vfU) and fine (fL), abundant.

Clay, interbedded dark gray $(5 Y 4 / 1)$, pale red (10 R 6/4), white $(10 Y R 8 / 1)$ and pale yellow $(2.5$ Y $7 / 4)$

Clay, interbedded dark gray $(5 Y 4 / 1)$, pale red (10 R 6/4), white (10 YR 8/1) and pale yellow (2.5 Y 7/4); sand, quartz, fine (fL), minor, mixed with yellow clay.

No sample.

Sand, quartz, medium ( $\mathrm{mL}$ ), subrounded, light gray (10 YR 7/1); clay, minor.

Sand, quartz, very fine (vfU), yellowish-brown (10 YR 5/8), silt, common.

Sand, quartz, very fine (vfU), light gray (10 YR 7/1); clay, abundant.

$\begin{array}{ll}180.0 & 20.0 \\ 220.0 & 40.0 \\ 240.0 & 20.0 \\ 260.0 & 20.0 \\ 280.0 & 20.0 \\ 300.0 & 20.0\end{array}$


Table 8.--Lithologic logs for well-cluster and borehole sites

[Codes enclosed in parentheses refer to the Munsell Soil Color Charts (1975)]

$\begin{array}{llcllll}\text { Term } & \text { Grain size (microns) : } & \text { Term } & & \text { Grain size (microns) : } & \text { Relative abundance descriptors: } \\ \mathrm{vcU}= & 1,410-2,000 & \mathrm{~mL} & = & 250-350 & \text { Abundant }>30 \% \\ \mathrm{vcL}= & 1,000-1,410 & \mathrm{fU} & = & 177-250 & \text { Common }>15 \% \text { and }<30 \% \\ \mathrm{cU}= & 710-1,000 & \mathrm{fL} & = & 125-177 & \text { Minor }>1 \% \text { and }<15 \% \\ \mathrm{cL}= & 500-710 & \mathrm{vfU} & = & 88-125 & \text { Trace }<1 \% \\ \mathrm{mU}= & 350-500 & \mathrm{vfL} & =62-88 & \end{array}$

Depth

(feet)

Thickness

(feet)

\section{Well cluster site 1}

Sand, quartz, fine (fU), brown (10 YR 4/3); silt, common; gradual boundary.

Sand, quartz, subangulur, medium (mU), mottled, very pale brown (10 YR 7/6); silt, common; gradual boundary.

Sand, quartz, medium ( $\mathrm{mU}$ ) to fine (fU), subrounded, mottled light gray (10 YR 7/1) and yellow (10 YR 7/6); gradual boundary.

Sand, quartz, medium (mU) to fine (fU); subrounded, mottled light gray (10 YR 7/1); color changes to yellow-brown (10 YR 5/8) and grayish-brown (10 YR 5/2) with depth; clear boundary.

Sand, quartz, medium (mU), subangular, brown (10 YR 5/3); clear boundary.

Sand, quartz, medium (mU) to coarse (cL), subangular, light gray (10 YR 7/1), and yellow-brown (10 YR 5/8), in oxidized beds.

Sand, quartz, fine (fU), dark gray (10 YR 4/1); silt, common; thin parallel bedding; abrupt boundary.

Sand, quartz, fine (fU), dark gray (10 YR 4/1); clay, gray (10 YR 5/1), common; silt, common; clear boundary.

Sand, quartz, medium (mU), gray (10 Y $5 / 1)$.

Sand, fine (fU), subrounded, gray (2.5 Y 4/1); coarsens downward to medium (mU).
0.9

4.0

6.5

8.0

10.8

2.8

14.0

18.0

18.7

19.0

21.5

24.0

29.0

31.0

34.0

39.0

41.5

44.0

50.0

55.0

59.0

64.0

69.0

72.0

75.0

90.0

15.0 
Table 8.-Lithologic logs for well-cluster and borehole sites

[Codes enclosed in parentheses refer to the Munsell Soil Color Charts (1975)]

$\begin{array}{lcclcl}\text { Term } & \text { Grain size (microns) : } & \text { Term } & & \text { Grain size (microns) : } & \text { Relative abundance descriptors: } \\ \mathrm{vcU}= & 1,410-2,000 & \mathrm{~mL} & = & 250-350 & \text { Abundant }>30 \% \\ \mathrm{vcL}= & 1,000-1,410 & \mathrm{fU} & = & 177-250 & \text { Common }>15 \% \text { and }<30 \% \\ \mathrm{cU}= & 710-1,000 & \mathrm{fL} & = & 125-177 & \text { Minor }>1 \% \text { and }<15 \% \\ \mathrm{cL}= & 500-710 & \mathrm{vfU} & = & 88-125 & \text { Trace }<1 \% \\ \mathrm{mU}= & 350-500 & \mathrm{vfL} & =62-88 & \end{array}$

\begin{tabular}{lll}
\hline Lithology & $\begin{array}{l}\text { Depth } \\
\text { (feet) }\end{array}$ & $\begin{array}{l}\text { Thickness } \\
\text { (feet) }\end{array}$ \\
\hline
\end{tabular}

Well cluster site 2

Clay, brown (10 YR 5/3), yellowish brown (10 YR 5/6) and dark reddish brown

1.0 (5 YR 5/3); sand, quartz, medium ( $\mathrm{mU}$ ) and very fine (vfU), subangular, abundant; roots and organic matter, abundant.

Sand, quartz, medium $(\mathrm{mL})$ to fine (fU), subangular, light brownish gray $(10 \mathrm{YR} 6 / 2)$ and brownish yellow (10 YR 6/6); clay, minor; gradual boundary.

Sand, quartz, medium ( $\mathrm{mU}$ and $\mathrm{mL}$ ), subangular, yellowish (10 YR 5/8) and gray $(10$ YR 5/1); clear boundary.

Clay, light gray (N7) and brownish yellow (10 YR 6/8); sand, quartz, very fine (vfU), common; abrupt boundary.

Sand, quartz, medium $(\mathrm{mL})$, subangular, light gray (10 YR 6/1) and light yellowish brown (2.5 Y 6/4); clay bed, light gray (10 YR 6/1), (appx. $0.5 \mathrm{~cm}$ thick), minor.

Sand, quartz, medium ( $\mathrm{mL}$ ), subangular, dark greenish gray (5 GY 4/1); clear boundary.

Sand, quartz, medium ( $\mathrm{mL}$ ), subangular, dark greenish gray (5 GY 4/1).

Sand, quartz, medium ( $\mathrm{mL}$ ) and fine (fU), subrounded, dark olive gray (5 Y $3 / 2)$.

Sand, quartz, fine (fU), subangular, very dark gray ( 5 Y $3 / 1$ ); silt, minor; gradual boundary; cemented sand at $24.5 \mathrm{ft}$.

Sand, quartz, very fine (vfU), dark olive gray ( 5 Y $3 / 2)$; silt, common; gradual boundary.

Clay, dark gray (5 Y4/2); silt, abundant; molds of bivalve shells; wood fragments, trace.

Clay, olive gray ( 5 Y 4/2); silt, abundant; gradual boundary.

Clay, dark greenish gray ( 5 GY $3 / 1)$; silt, abundant.

Clay, olive gray (5 Y 4/2); silt, common; molds of bivalve shells, minor; organic matter, trace.

Clay, dark olive gray $(5 Y 3 / 2)$ and olive $(5$ Y $5 / 3)$; silt, abundant; clay has fractured appearance, breaks into chunks $(0.5-2.0 \mathrm{~cm})$.

Clay, dark olive gray (5 Y 3/2); silt, abundant; massive.

10.5

15.0

19.0

24.0

25.0

29.0

Clay, dark greenish gray (5 GY $3 / 1)$; silt, abundant; massive; clear boundary.

Clay, dark greenish gray ( $5 \mathrm{GY} 3 / 1)$; clay breaks into angular fragments (0.1-2.0 cm); clear boundary.

Clay, dark greenish gray ( $5 \mathrm{GY} 3 / 1)$; clay breaks into angular fragments $(0.1-2.0 \mathrm{~cm})$; clear boundary.

Clay, dark olive gray (5 Y 3/2); silt, abundant; thin uniform bedding, (approx. $2.0 \mathrm{~mm}$ thick).

4

Clay, dark olive gray ( 5 Y $3 / 2)$; silt, abundant; thin wavy bedding (<.1 mm).

Clay, olive gray ( 5 Y 4/2); silt, abundant; faint thin $(<.1 \mathrm{~mm})$ bedding.

Sand, quartz, fine (fU and $\mathrm{fL}$ ), dark olive gray $(5 \times 3 / 2)$; pebbles, subrounded,

Sand, quartz, fine (fL); dark grayish brown ( $25 \mathrm{Y} 4 / 2)$; abrupt boundary.
Sand, quartz, medium ( $\mathrm{mU}$ ) to coarse (cU and $\mathrm{cL}$ ); subangular, dark grayishbrown $(2.5 \times 4 / 2)$.

No sample 
Table 8.-Lithologic logs for well-cluster and borehole sites

[Codes enclosed in parentheses refer to the Munsell Soil Color Charts (1975)]

$\begin{array}{llllll}\text { Term } & \text { Grain size (microns) : } & \text { Term } & \text { Grain size (microns) : } & \text { Relative abundance descriptors: } \\ \mathbf{v c U}= & 1,410-2,000 & \mathrm{~mL} & = & 250-350 & \text { Abundant }>30 \% \\ \mathrm{vcL}= & 1,000-1,410 & \mathrm{fU} & = & 177-250 & \text { Common }>15 \% \text { and }<30 \% \\ \mathrm{cU}= & 710-1,000 & \mathrm{fL} & = & 125-177 & \text { Minor }>1 \% \text { and }<15 \% \\ \mathrm{cL}= & 500-710 & \text { vfU } & = & 88-125 & \text { Trace }<1 \% \\ \mathrm{mU}= & 350-500 & \text { vfL } & =62-88 & \end{array}$

\begin{tabular}{lll}
\hline Lithology & $\begin{array}{l}\text { Depth } \\
\text { (feet) }\end{array}$ & $\begin{array}{l}\text { Thickness } \\
\text { (feet) }\end{array}$ \\
\hline
\end{tabular}

Well cluster site 3

Sand, quartz, fine (fL), dark yellowish brown (10 YR 3/6); root and organic zone;

0.8 silt, common; gradual boundary.

Sand, quartz, fine (fU), mottled yellowish brown (10 YR 6/1) and gray (10 YR 6/1); clay, minor; gradual boundary.

Sand, quartz, medium (mL), subrounded, yellowish brown (10 YR 5/4) and gray (10 YR 6/1); abrupt boundary.

Sand, quartz, medium (mL), subrounded, yellowish brown (10 YR 5/4), abrupt boundary.

Sand, quartz, very fine (vfL), dark gray (5Y 4/); silt, common.

Clay, gray (5 Y 5/1); silt, common.

Sand, quartz, fine (fL), subangular, gray (5 Y 6/1).

Sand, quartz, fine (fL), rounded, well sorted, light olive gray ( 5 Y 6/2); mica, trace.

Sand, quartz, fine (fU), subrounded, gray $(5 Y 5 / 1)$; thinly bedded $(1.0-2.0 \mathrm{~cm})$;

organic material, trace.

Sand, quartz, fine (fL); clay, olive (5 Y 4/3), minor; mica, minor; organic material, trace.

Sand, quartz, fine ( $\mathrm{fL}$ ); clay, olive (5 Y 4/3), minor; mica minor; organic material, trace.

Sand, quartz, fine ( $f U$ to $\mathrm{fL}$ ), rounded, olive gray ( 5 Y 4/2); clay, minor; mica, minor;

Sand, quartz, very fine (fU to vfU), olive gray ( 5 Y $5 / 2$ ); clay, minor; mica, minor; organic material, trace.

Clay, dark gray (5Y 4/1); silt, common; mica, minor; organic material, trace.

Clay, olive gray ( 5 Y $5 / 2)$; mica, minor; organic material, trace; quartz pebbles $(0.25 \mathrm{~cm})$, rounded, trace.

Clay, olive gray (5Y 5/2); silt, common; mica, minor; shell fragments and organic material, trace.

Sand, fine (fL), dark gray (5 Y 4/1); clay, common, breaks along partings; bivalve casts and shell fragments, minor; mica, trace.

Sand, fine (fL), dark gray ( 5 Y 4/1); clay, minor; shell fragments, minor; mica, trace; silty lens 2.0-3.0 in. thick at $47.0 \mathrm{ft}$, light olive gray ( 5 Y 6/2), very hard.

Clay, very dark gray ( $5 Y 3 / 1$ ); organic material, trace; sand, fine (vfU- fU), trace.

Clay, very dark gray $(5 Y 3 / 1)$; silt, trace; organic material and small shell fragments, trace.

Clay, very dark gray $(5 \times 3 / 1)$; sand, fine (fU), subrounded, well sorted, minor; mica, minor; gradual, boundary.

Sand, medium to coarse ( $\mathrm{mU}$ to $\mathrm{cL}$ ), poorly sorted; gravel, coarse $(<1.0 \mathrm{~cm}$ ), subangular; sand, quartz, subrounded; clay, minor; clay lens, dark gray (5 Y 4/1), from $73.0-73.5 \mathrm{ft}$.

No sample. 
Table 8.--Lithologic logs for well-cluster and borehole sites

[Codes enclosed in parentheses refer to the Munsell Soil Color Charts (1975)]

$\begin{array}{llllll}\text { Term } & \text { Grain size (microns) : } & \text { Term } & \text { Grain size (microns) : } & \text { Relative abundance descriptors: } \\ \mathrm{vcU}=1,410-2,000 & \mathrm{~mL} & = & 250-350 & \text { Abundant }>30 \% \\ \mathrm{vcL}= & 1,000-1,410 & \mathrm{fU} & = & 177-250 & \text { Common }>15 \% \text { and }<30 \% \\ \mathrm{cU}= & 710-1,000 & \mathrm{fL} & = & 125-177 & \text { Minor }>1 \% \text { and }<15 \% \\ \mathrm{cL}= & 500-710 & \mathrm{vfU} & =88-125 & \text { Trace }<1 \% \\ \mathrm{mU}= & 350-500 & \mathrm{vfL} & =62-88 & \end{array}$

Lithology

$\begin{array}{ll}\text { Depth } & \text { Thickness } \\ \text { (feet) } & \text { (feet) }\end{array}$

Well cluster site 4

Sand, medium $(\mathrm{mL})$, subrounded, mixed dark yellowish brown (10 YR 4/6) and pale brown

2.0 (10 YR 6/3).

Sand, fine (fL), mottled yellowish brown (10 YR 5/4) and gray (10YR 6/1); silt, common.

Sand, fine (fL), gray (10 YR 6/1), thinly bedded; silt, common.

Sand, fine (fL), light gray (5 YR 6/1) with reddish-yellow (2.5 YR 6/8) and

dark red (2.5 YR 3/8) mottles; silt, common.

Sand, quartz, medium (mL), subangular, light brownish-gray (10 YR 6/2) with brownish-yellow (10 YR 6/8) mottles; gradual boundary.

Sand, quartz, fine (fU), subrounded, gray ( 10 YR 6/2) to pale red (10 YR 6/3); thinly bedded (1.0-2.0 mm thick).

Sand, quartz, fine (fU), subrounded, gray (10 YR 6/2) to reddish-yellow (5 YR 6/8) to red ( 2.5 YR 4/8), thinly bedded $(0.5-2.0 \mathrm{~cm}$ thick).

Sand, quartz, fine (fU); silt, dark gray (5Y 4/1), trace.

Sand, quartz, fine ( $\mathrm{fL}$ ), subrounded, olive gray (5 Y 4/1); silt, common; abrupt boundary.

Sand; quartz, medium (mL), light gray (N7), subangular.

No sample

Sand, quartz, medium (mL), subangular, light gray (N3); abrupt boundary.

Sand, quartz, fine (fU), subrounded, olive gray (5 Y 4/1) $(20-25 \mathrm{~cm}$ thick); interbedded with silt, dusky yellowish-brown ( 10 YR $2 / 2)(1.0-3.0 \mathrm{~cm}$ thick); fine organic particles disseminated throughout core.

Sand, quartz, fine $(\mathrm{fL})$, subrounded, olive gray ( 5 Y 3/2); faint bedding (1.0-5.0 $\mathrm{mm}$ thick); organic debris (sticks, fine particles), abundant; silt, trace.

Sand, quartz, fine (fL), subrounded, olive gray ( 5 Y 3/2); gradual boundary.

Sand, quartz, very fine (vfL), olive gray (5Y 4/1); silt, common; massive.

Clay, olive gray ( 5 Y $3 / 2)$; faint, thin bedding; silt, common; abrupt boundary.

Mixed, clay, olive gray $(5 Y 3 / 2)$ and silt, light olive gray $(5 Y 6 / 1)$; sand, quartz, fine (fU), trace.

Clay, olive gray ( 5 Y $3 / 2)$, highly fractured; silt, common; clear boundary.

Clay, oljve gray ( 5 Y $3 / 2)$; bivalve shells, $(2.0-3.0 \mathrm{~cm})$, abundant; silt, common.

Clay, olive gray $(5 Y 3 / 2)$; bivalve shells $(2.0-3.0 \mathrm{~cm})$, fragments and whole shells, abundant; silt, common.

Clay, olive gray $(5 Y 3 / 2)$; bivalve fragments and whole shells $(2.0-3.0 \mathrm{~cm})$.

Clay, olive gray ( 5 Y $3 / 2)$; sand, quartz, very fine (vfL), trace; shell fragments, common; silt, common.

Clay, olive gray (5Y $3 / 2)$; silt, common; massive.

Clay, olive gray $(5 Y 3 / 2)$ with large yellowish-gray mottles $(5 Y 7 / 2)$; bivalve casts in clay; sand, quartz, very fine (vfL), minor.

Sand, quartz, very fine (vfL), olive gray $(6 \times 3 / 2)$; al ternating with silt beds, light olive gray (5 Y 5/2) (1.0-5.0 $\mathrm{mm}$ thick); abrupt boundary.

Sand, quartz, medium ( $\mathrm{mU}$ ) and coarse ( $\mathrm{CL}$ ), subrounded to round; gravel, quartz and rock fragments of granitic/metamorphic origin; silt, olive gray $(5 \times 3 / 2)$, minor.

No sample.

$\begin{array}{rr}3.7 & 1.7 \\ 6.7 & 3.0 \\ 8.0 & 1.3 \\ & \\ 15.5 & 7.5\end{array}$

17.4

18.7

19.0

.3

$19.8 \quad .8$

22.0

2.2

24.0

24.6

29.0 
Table 8.--Lithologic logs for well-cluster and borehole sites

[Codes enclosed in parentheses refer to the Munsel] Soil Color Charts (1975)]

$\begin{array}{llllll}\text { Term } & \text { Grain size (microns) : } & \text { Term } & \text { Grain size (microns) : } & \text { Relative abundance descriptors: } \\ \mathbf{v c U}= & 1,410-2,000 & \mathrm{~mL} & = & 250-350 & \text { Abundant }>30 \% \\ \mathrm{vcL}= & 1,000-1,410 & \mathrm{fU} & = & 177-250 & \text { Common }>15 \% \text { and }<30 \% \\ \mathrm{cL}= & 710-1,000 & \mathrm{fL} & = & 125-177 & \text { Minor }>1 \% \text { and }<15 \% \\ \mathrm{cL}= & 500-710 & \mathrm{vfU} & =88-125 & \text { Trace }<1 \% \\ \mathrm{mU}= & 350-500 & \mathrm{vfL} & =62-88 & \end{array}$

$\begin{array}{ll}\begin{array}{l}\text { Depth } \\ \text { (feet) }\end{array} & \begin{array}{l}\text { Thickness } \\ \text { (feet) }\end{array}\end{array}$

\section{Well cluster site 5}

Sand, quartz, fine (fU and fL), subrounded, dark yellowish brown (10 YR 4/4); silt and clay, common; contains artifacts (burned glass and metal); clear boundary.

Sand, quartz, medium (mL), subrounded, strong brown (7.5 YR 4/6); gradual boundary.

Sand, quartz, very fine (vfL), mottled light gray (10 YR 7/1) and brownish-yellow (10YR 6/6); clear boundary.

Sand, quartz, fine (fU), brownish-yellow (10 YR 6/6).

Sand, quartz, medium (mU) and fine (fU), subangular, mottled yellowish brown (10 YR 5/8) and light gray ( 5 Y $7 / 2)$; clay, abundant.

Sand, quartz, very fine (vfU), mottled yellowish-brown (10 YR5/6) and gray (5 Y 5/1); clay, common; clear boundary.

Sand, quartz, very fine (vfU), dark gray ( 5 Y 4/1); abrupt boundary.

Sand, quartz, coarse ( $\mathrm{cU}$ and $\mathrm{Cl}$ ) and very coarse (vcU) subangular, light yellowish-brown $(2.5 Y 6 / 4)$; color changes to gray $(5 Y 5 / 1)$ at $13.0 \mathrm{ft}$.

Sand, quartz, medium (mU) and coarse ( $(\mathrm{CL})$, subrounded, olive gray $(5 Y 5 / 2)$; clear boundary.

Sand, quartz, very tine (ufL), olive gray ( 5 Y 4/2); silt, common.

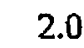

Sand, quartz, medium ( $\mathrm{mL}$ ), subrounded, olive gray ( 5 Y 4/2)

Sand, quartz, fine (fL and $f U$ ), subrounded, olive gray ( 5 Y 4/2); clay, abundant; peat, trace; faint bedding.

No sample.

Sand, quartz, medium ( $\mathrm{mL}$ ) and fine (fU), subrounded, olive gray (5 Y 4/2); clear boundary.

Clay, olive gray ( 5 Y 4/2); sand, quartz, very fine (vfU), common; shells, bivalves, whole and fragments, minor.

Clay, dark gray (5 Y 4/1); silt, minor; molds of bivalves, minor; shell fragments, trace.

Clay, dark gray ( 5 Y 4/1); silt, minor; shells, bivalves, whole (up to $5.0 \mathrm{~cm}$ ) and fragments, abundant.

Clay, dark gray (5 Y 4/1); silt, minor; shells, bivalves, whole and fragments, common.

Clay, dark gray (5 Y 4/1); silt, minor; shells, bivalves, whole and fragments, common.

Clay, dark gray (5 Y 4/1); silt, common; shell fragments, bivalves, minor; clear boundary.

Clay, dark gray (5 Y 4/1) with olive (5 Y 5/3) mottles; silt, common; shell fragments.

Clay, dark gray ( $5 Y 4 / 1)$ with olive $(5 Y 5 / 3)$ mottles; silt, common; shell fragments, minor.

Clay, dark gray $(5 Y 4 / 1)$ with olive $(5 Y 5 / 3)$ mottles; silt, common; shell fragments, minor.

Clay, mottled dark gray ( 5 Y 4/1) and olive ( 5 Y 5/3); silt, abundant; shell fragments, trace; sand, quartz, very fine (vfU), occurs as thin coatings on clay partings, trace.

Clay, olive gray ( 5 Y 4/2) with olive ( 5 Y 5/3) mottles; sand, quartz, very fine (vfL), minor; silt, minor; shell debris, trace.
3.5 
Table 8.--Lithologic logs for well-cluster and borehole sites

[Codes enclosed in parentheses refer to the Munsell Soil Color Charts (1975)]

$\begin{array}{llclll}\text { Term } & \text { Grain size (microns) : } & \text { Term } & \text { Grain size (microns) : } & \text { Relative abundance descriptors: } \\ \mathrm{vcU}= & 1,410-2,000 & \mathrm{~mL} & = & 250-350 & \text { Abundant }>30 \% \\ \mathrm{vcL}= & 1,000-1,410 & \mathrm{fU} & = & 177-250 & \text { Common }>15 \% \text { and }<30 \% \\ \mathrm{cU}= & 710-1,000 & \mathrm{fL} & = & 125-17 & \text { Minor }>1 \% \text { and }<15 \% \\ \mathrm{cL}= & 500-710 & \mathrm{vfU} & = & 88-125 & \text { Trace }<1 \% \\ \mathrm{mU}= & 350-500 & \mathrm{vfL} & = & 62-88 & \end{array}$

\section{Well cluster site 5 -Continued}

Clay, olive gray $(5 Y 4 / 2)$ with pale olive $(5 Y 6 / 3)$ mottles; sand, quartz, very fine 89.0 (vfL), minor; silt, minor; some mottles are harder than surrounding material.

Clay, olive gray (5 Y 4/2) with pale olive ( 5 Y $6 / 3$ ) mottles; sand, quartz, very fine (vfL), minor; silt, minor; clay beds are separated by thin $(0.1 \mathrm{~mm})$ sand beds; sand, quartz, very fine (vfU), dark gray (5Y 4/1); clay beds (1.0-10.0 mm thick) sand beds occur intermittently.

Clay, interbedded very dark gray $(5 Y 3 / 1)$, dark olive gray $(5 Y 4 / 1)$, and olive yellow (5 Y 6/6); sand, quartz, very fine (vfU), occurs in clay matrix and as coatings between clay beds; clay beds ( $1.0 \mathrm{~mm}$ thick).

Clay, interbedded very dark gray $(5 Y 3 / 1)$, olive gray $(5 Y 4 / 1)$, and olive yellow ( 5 Y 6/6); sand, quartz, very fine ( $v f U$ ), occurs in clay matrix and as coatings between clay beds, clay beds $(1,0-2.0 \mathrm{~cm}$ thick).

Silt, interbedded, dark gray ( 5 Y 4/1) and olive gray (5 Y 4/3); clay, common; sand, quartz, very fine (vfU), common, sand occurs in silt matrix and as coatings between beds; clear boundary.

Peat, organic zone, very dark gray (10 YR 3/1); clay, common; sand, quartz, fine

Silt, interbedded, dark gray ( $5 Y 4 / 1)$, olive gray (5 Y 4/1), and olive yellow

(5Y 6/6); sand, quartz, very fine (vfU), occurs in clay matrix and as coatings between clay beds; thin organic zones $(2.0-5.0 \mathrm{~cm})$ and some thin $(1.0-5.0 \mathrm{~m})$ zones containing sand, quartz, medium $(\mathrm{mU})$ and coarse $(\mathrm{cU})$ from $112.0-114.0 \mathrm{ft}$. 
Table 8.--Lithologic logs for well-cluster and borehole sites

\begin{tabular}{|c|c|c|c|c|c|}
\hline \multicolumn{6}{|c|}{ [Codes enclosed in parentheses refer to the Munsell Soil Color Charts (1975)] } \\
\hline Term & & Grain size (microns) & Term & Grain size (microns) : & Relative abundance descriptors: \\
\hline $\mathrm{vcU}$ & $=$ & $1,410-2,000$ & $\mathrm{~mL}$ & $250-350$ & Abundant $>30 \%$ \\
\hline vcL & $=$ & $1,000-1,410$ & $\mathrm{fU}$ & $177-250$ & Common $>15 \%$ and $<30 \%$ \\
\hline $\mathrm{cU}$ & $=$ & $710-1,000$ & $\mathrm{fL}$ & $125-177$ & Minor $>1 \%$ and $<15 \%$ \\
\hline $\mathrm{cL}$ & $=$ & $500-710$ & vfU & $88-125$ & Trace $<1 \%$ \\
\hline $\mathrm{mU}$ & $=$ & $350-500$ & vfl & $62-88$ & \\
\hline
\end{tabular}

\begin{tabular}{lll}
\hline Lithology & $\begin{array}{l}\text { Depth } \\
\text { (feet) }\end{array}$ & $\begin{array}{l}\text { Thickness } \\
\text { (feet) }\end{array}$ \\
\hline
\end{tabular}

\section{Well cluster site 6}

Sand, quartz, fine (fU), brown (10 YR 4/3); silt, common.

Silt, gray $(10$ YR $6 / 1)$, light yellowish brown $(2.5$ Y $6 / 4)$, greenish gray

$1.5 \quad 1.5$

( 5 GY $5 / 1)$, bluish gray $(5 \mathrm{~B} 6 / 1)$; well bedded; plant remains, abundant; clear boundary.

Sand, quartz, fine (fU), subrounded, black (10YR 1/1) and gray (10 YR 5/1).

No sample.

Sand, quartz, fine (fU and $\mathrm{fL}$ ), subrounded, light olive gray (5 Y 6/2); clear boundary.

Sand, quartz, fine (fU), light yellowish brown (2.5 Y 6/4).

Sand, quartz, medium (mL), subangular, brownish yellow (10 YR 6/6).

Sand, quartz, fine (fL), light brownish gray (10 YR 6/2); clear boundary.

Sand, quartz, fine (fU), strong brown (7.5 YR 5/8); abrupt boundary.

Sand, quartz, fine (fU), dark gray (5Y $4 / 1$ ).

$\begin{array}{ll}2.8 & 1.3 \\ & \\ 4.0 & 1.2 \\ 6.0 & 2.0 \\ 7.2 & 1.2\end{array}$

Clay, dark gray (5 Y 4/1); sand, quartz, fine (fL), subangular, abundant; abrupt boundary.

Sand, quartz, medium ( $\mathrm{mU}$ ), subrounded, dark gray (5 Y 4/1); clear boundary.

Sand, quartz, very fine (vfU), dark gray $(5 Y 4 / 1)$; silt, minor.

Sand, quartz, very fine (vfU), dark gray ( 5 Y $4 / 1$ ); silt, minor; gradual boundary.

Sand, quartz, very fine (vfU), dark gray ( 5 Y 4/1); clay, common; gradual boundary.

$\begin{array}{rr}9.0 & 1.8 \\ 10.0 & 1.0 \\ 11.6 & 1.6 \\ 12.3 & .7 \\ 19.0 & 6.7 \\ & \\ 22.2 & 3.2 \\ & \\ 23.5 & 1.3 \\ 24.0 & .5 \\ 28.0 & 4.0 \\ 29.0 & 1.0 \\ & \\ 34.0 & 5.0 \\ 35.5 & 1.5 \\ 39.0 & 3.5 \\ & \\ 39.7 & .7 \\ 44.0 & 4.3\end{array}$

Clay, dark gray (5Y 4/1); silt, abundant; bivalve shells, whole, decomposed, minor.

Clay, dark olive gray $(5 Y 3 / 2)$ and olive gray ( 5 Y $4 / 2)$; silt, abundant; clear boundary.

Clay, dark olive gray (5Y 3/2); silt, abundant; sand, quartz, very fine, trace; organic zones, black (N1), minor.

Clay, dark gray (5 Y 4/1); silt, common; molds and casts of bivalve shells, common, but no $\mathrm{CaCO}_{3}$ present; gradual boundary.

Clay, dark gray ( 5 Y 4/1); silt, common; bivalve shells, minor to abundant, $(0.5-5.0 \mathrm{~cm})$; shells occur in beds, thickest at $42.0-42.5 \mathrm{ft}$.

1.5

1.3

1.2

2.0

1.2

1.8

1.0

.6

6.7

3.2

1.3

.5

4.0

1.0

5.0

1.5

3.5

.7

$49.0 \quad 5.0$

$54.0 \quad 5.0$

$59.0 \quad 5.0$

$64.0 \quad 5.0$

$69.0 \quad 5.0$

lay, dark olive gray ( 5 Y $3 / 2$ ); silt, common; sand, quartz, very fine (vfU), trace; rippled appearance.

Clay, olive gray (5 Y 4/2) with few olive ( 5 Y 5/3) mottles; sand, quartz, very fine, trace; rippled appearance.

Clay, olve gray ( 5 Y $4 / 2$ ) with few ohve ( 5 Y $5 / 3$ ) mottles; sand, quart $z$, very fine, trace; rippled appearance.

Clay, interbedded dark olive gray and pale olive ( 5 Y $6 / 3)$; silt, minor; sand, quartz, very fine (vfU), occur as thin $(<1.0 \mathrm{~mm})$ beds, minor; organic bed, trace.

Clay, interbedded dark olive gray and pale olve (5 Y 6/3); silt, minor; sand, quartz, very fine (vfU), occurs as thin $(<1.0 \mathrm{~mm})$ beds common; organic bed, trace.

Clay, dark olive gray (5Y $3 / 2)$ with few beds pale olive $(5 Y 6 / 3),(1.0 \mathrm{~cm}$ thick); silt, common; sand, quart $z$, very fine (vfU), occurs as thin coatings between clay beds, common; clay' is well bedded (approx. 0.2-0.5 cm thick).

$\begin{array}{ll}74.0 & 5.0 \\ 79.0 & 5.0 \\ 84.0 & 5.0 \\ 89.0 & 5.0 \\ 93.0 & 4.0\end{array}$


Table 8.--Lithologic logs for well-cluster and borehole sites

[Codes enclosed in parentheses refer to the Munsell Soil Color Charts (1975)|

\begin{tabular}{|c|c|c|c|c|c|}
\hline Term & & Grain size (microns): & Term & Grain size (microns) & Relative abundance descriptors: \\
\hline $\mathrm{vcU}$ & $=$ & $1,410-2,000$ & $\mathrm{~mL}$ & $250-350$ & Abundant $>30 \%$ \\
\hline $\mathrm{vcL}$ & $=$ & $1,000-1,410$ & $\mathrm{fU}$ & $177-250$ & Common $>15 \%$ and $<30 \%$ \\
\hline $\mathrm{cU}$ & $=$ & $710-1,000$ & $\mathrm{fl}$. & $125-177$ & Minor $>1 \%$ and $<15 \%$ \\
\hline $\mathrm{cL}$ & $=$ & $500-710$ & $v f U$ & $88-125$ & Trace $<1 s_{0}$ \\
\hline $\mathrm{mU}$ & $=$ & $350-500$ & $v \mathrm{fL}$ & $62-88$ & \\
\hline
\end{tabular}

\begin{tabular}{lll}
\hline Lithology & $\begin{array}{l}\text { Depth } \\
\text { (fieet) }\end{array}$ & $\begin{array}{l}\text { Thickness } \\
\text { (fcet) }\end{array}$ \\
\hline
\end{tabular}

Well cluster site $6-$-Continued

Clay, dark olive gray $(5 Y 3 / 2)$ with few beds pale olive $(5 Y 6 / 3),(1.0 \mathrm{~cm}$ thick);

94.0 1.0

silt, common; sand, quartz, very fine ( $v f U$ ), occurs as thin coatings between clay beds, common; clay is well bedded $(0.2-0.5 \mathrm{~cm}$ thick); sand, quartz, coarse ( $\mathrm{cL}$ ) and medium (mU); occurs as $1.0-2.0 \mathrm{~cm}$ thick beds, minor.

Sand, quartz, medium ( $\mathrm{mU}$ ) to coarse (cL), subrounded, black (5 Y 2.5/1);

96.0 interbedded with clay, olive gray ( $5 Y 4 / 2)$; silt, common; gradual boundary.

Clay, dark otive gray $(5 Y 3 / 2)$; silt, common; organc material, fine, disseminated and in clumps, black $(5 Y 2.5 / 1)$; pebbles $(2.0-5.0 \mathrm{~cm})$, well rounded, minor.

No sample
99.0

3.0

100.0

1.0 
Table 8.--Lithologic logs for well-cluster and borehole sites

[Codes enclosed in parentheses refer to the Munsell Soil Color Charts (1975)]

$\begin{array}{lcllll}\text { Term } & \text { Grain size (microns) : } & \text { Term } & \text { Grain size (microns) : } & \text { Relative abundance descriptors: } \\ \mathrm{vcU}=1,410-2,000 & \mathrm{~mL} & =250-350 & \text { Abundant }>30 \% \\ \mathrm{vcL}=1,000-1,410 & \mathrm{fU} & = & \mathrm{fL} & \text { Common }>15 \% \text { and }<30 \% \\ \mathrm{cU}= & 710-1,000 & \mathrm{fL} & =125-177 & \text { Minor }>1 \% \text { and }<15 \% \\ \mathrm{cL}= & 500-710 & \mathrm{vfU} & =88-125 & \text { Trace }<1 \% \\ \mathrm{mU}= & \mathrm{vfL} & =62-88 & \end{array}$

\begin{tabular}{lll}
\hline Lithology & $\begin{array}{l}\text { Depth } \\
\text { (feet) }\end{array}$ & $\begin{array}{l}\text { Thickness } \\
\text { (feet) }\end{array}$ \\
\hline
\end{tabular}

\section{Well cluster site 7}

Sand, quartz, fine (fL), subrounded, brownish yellow (10 YR 6/6); gradual boundary.

Sand, quartz, very fine (vfU), mottled light brownish gray ( $10 \mathrm{YR} 6 / 2)$ and brownish yellow (10 YR 6/6); clay, abundant.

Sand, quartz, fine (fL), mottled yellowish brown (10 YR 5/8) and light gray (10 YR 7/1); silt, abundant.

Sand, quartz, medium (mU), very pale brown $(10$ YR $7 / 30)$; silt layers $(2.0-4.0 \mathrm{~cm}$ thick) at $11.2 \mathrm{ft}$ and $12.5 \mathrm{ft}$, light brownish gray $(10 \mathrm{YR} 6 / 2)$.

Sand, quartz, medium ( $\mathrm{mL}$ ), brownish yellow (10 YR 6/6); clear boundary.

Sand, quartz, medium (mU), strong brown (7.5 YR 5/8); abrupt boundary.

Sand, quartz, fine (fL), dark gray (5 Y 4/1).

Sand, quartz, medium ( $\mathrm{mU}$ ), subrounded, light olive brown (2.5 Y 5/4) mixed with sand, quartz, very fine (vfU), dark olive gray ( $5 Y 3 / 2)$; clear boundary.

Sand, quartz, very fine (vfU), dark olive gray ( $5 Y 3 / 2$ ).

Sand, quartz, very fine (vfU), dark olive gray ( 5 Y $3 / 2$ ); interbedded with silt, olive gray (5 Y $4 / 2)(4.0-5.0 \mathrm{~cm}$ thick); shell molds, bivalves, minor; plant remains, trace.

Sand, quartz, fine (fL), very dark gray ( 5 Y $3 / 1)$; silt, minor; gradual boundary.

Sand, quartz, fine ( $\mathrm{fL}$ ), dark olive gray ( 5 Y $3 / / 2$ ); clay, minor.

Sand, quartz, fine (fL), dark olive gray ( 5 Y $3 / 2)$; clay, minor.

Sand, quartz, very fine (vfL), very dark gray $(5 Y 3 / 1)$; clay, common; clear boundary.

Sand, quartz, very fine (vfL), very dark gray ( 5 Y $3 / 1$ ); day, minor; clear boundary.

Clay, very dark gray $(5 \times 3 / 1)$; silt, common; shell impressions, bivalves; massive.

Clay, dark gray ( 5 Y4/1); silt, common; shells, bivalves, fragments and whole (approx. $2.0 \mathrm{~cm}$ ); thin, bedding $(0.5 \mathrm{~cm}$ thick $)$.

Clay, dark olive gray (5Y3/2); silt, common; shells, bivalves, fragments, abundant; bedding, thin (appx. $0.5 \mathrm{~cm}$ ); better developed at top of core.

Clay, dark olive gray $(5$ Y $3 / 2)$ with light olive gray $(5$ Y $6 / 2)$ mottles; silt, minor; shells, bivalve fragments, minor.

Clay, dark olive gray $(5$ Y $3 / 2)$ with few light olive gray (5 Y $6 / 2)$ mottles; silt, minor; shells, bivalve fragments, minor.

Clay, dark olive gray (5 Y $3 / 2$ ) with light olive gray (5 Y $6 / 2)$ mottles; silt, minor; shells, whole and fragments, common.

$\begin{array}{ll}31.4 & 2.4 \\ 32.9 & 1.5 \\ 34.0 & 1.1 \\ 38.0 & 4.0 \\ 39.0 & 1.0 \\ & \\ 44.0 & 5.0 \\ 50.0 & 6.0 \\ 55.5 & 5.5 \\ 60.0 & 4.5 \\ 65.0 & 5.0 \\ 69.0 & 4.0 \\ 74.0 & 5.0 \\ 79.0 & 5.0 \\ & \\ 84.0 & 5.0 \\ 89.0 & 5.0\end{array}$


Table 8.--Lithologic logs for well-cluster and borehole sites

[Codes enclosed in parentheses refer to the Munsell Soil Color Charts (1975)]

\begin{tabular}{|c|c|c|c|c|c|c|}
\hline Term & & Grain size (microns) : & Term & & ain size (microns) : & Relative abundance descriptors: \\
\hline $\operatorname{vcU}$ & $=$ & $1,410-2,000$ & $\mathrm{~mL}$ & $=$ & $250-350$ & Abundant $>30 \%$ \\
\hline vcL & $=$ & $1,000-1,410$ & $\mathfrak{U}$ & $=$ & $177-250$ & Common $>15 \%$ and $<30 \%$ \\
\hline $\mathrm{cU}$ & $=$ & $710-1,000$ & $\mathrm{fL}$ & $=$ & $125-177$ & Minor $>1 \%$ and $<15 \%$ \\
\hline cL & $=$ & $500-710$ & viU & $=$ & $88-125$ & Trace $<1 \%$ \\
\hline $\mathrm{mU}$ & $=$ & $350-500$ & vfL & $=$ & $62-88$ & \\
\hline
\end{tabular}

\begin{tabular}{lrr}
\hline Lithology & $\begin{array}{l}\text { Thickness } \\
\text { (feet) }\end{array}$ & (feet) \\
\hline
\end{tabular}

Well cluster site 7-Continued

Clay, dark olive gray ( 5 Y 3/2) with pale olive (5 Y 6/4) mottles; silt, minor; sand, quartz, very fine (vfL), minor; faint bedding $92-94 \mathrm{ft}$.

Clay, dark olive gray (5 Y 3/2); interbedded with clay, pale yellow (5 Y 7/2) and sand, quartz, very fine (vfU), dark olive gray (5 Y 3/2); beds (1.0-2.0 $\mathrm{mm}$ thick).

Clay, dark gray (5 Y 4/1) with pale yellow (5 Y 7/4) mottles; silt, minor; interbedded with clay, light gray (N7); beds (1.0-6.0 cm thick); sand, quartz, very fine (viU) occurs as coatings between beds.

Clay, dark gray (5Y 4/1) with pale yellow (5 Y 7/4) mottles; silt, minor; interbedded with clay, light gray (N7); beds $(0.5-2.0 \mathrm{~cm}$ thick); sand, quartz, very fine (viU) occurs as coatings between beds.

Clay, interbedded dark gray (5Y 4/1) and pale olive (5Y 6/3); silt, minor, occurs as thin $(<1.0 \mathrm{~mm}$ ) laminations between clay beds; individual beds of clay are $1.0-2.0 \mathrm{~mm}$ thick.

Clay, olive gray (5Y 4/2) with pale olive (5Y 6/4) mottles; silt, abundant; sand, quartz, medium (mL), subrounded, minor, occurs as thin beds (0.1-1.0 cm thick) and mixed with clay; organic beds composed of leaves and sticks $(2.0-3.0 \mathrm{~cm}$ thick), minor; bedding (1.0-5.0 mm thick), separated by sand coatings.

Clay, olive gray (5Y 4/2) with pale olive (5 Y 6/4) mottles; silt, abundant; sand, quartz, medium (mL), subrounded; minor, occurs as thin beds $(0.1-1.0 \mathrm{~cm}$ thick and mixed in clay; organic beds composed of leaves and sticks, $(2.0-3.0 \mathrm{~cm}$ thick), minor; bedding is $1.0-5.0 \mathrm{~mm}$ thick separated by sand coatings; sand zone at $119 \mathrm{ft}$ is approx. $15 \mathrm{~cm}$ thick. 
Table 8.--Lithologic logs for well-cluster and borehole sites

[Codes enclosed in parentheses refer to the Munsell Soil Color Charts (1975)]

$\begin{array}{lcllll}\text { Term } & \text { Grain size (microns): } & \text { Term } & \text { Grain size (microns) : } & \text { Relative abundance descriptors: } \\ \mathrm{vcU}=1,410-2,000 & \mathrm{~mL} & =250-350 & \text { Abundant }>30 \% \\ \mathrm{vcL}=1,000-1,410 & \mathrm{fU} & =177-250 & \text { Common }>15 \% \text { and }<30 \% \\ \mathrm{cU}= & 710-1,000 & \mathrm{fL} & =125-177 & \text { Minor }>1 \% \text { and }<15 \% \\ \mathrm{CL}= & 500-710 & \mathrm{vfU} & =88-125 & \text { Trace }<1 \% \\ \mathrm{mU}= & \mathrm{vfL} & =62-88 & \end{array}$

\begin{tabular}{lll}
\hline Lithology & $\begin{array}{l}\text { Depth } \\
\text { (feet) }\end{array}$ & $\begin{array}{l}\text { Thickness } \\
\text { (feet) }\end{array}$ \\
\hline
\end{tabular}

\section{Well cluster site 8}

Sand, quartz, very fine (vfU), brown (10 YR 5/3); silt, abundant; clear boundary.

Sand, quartz, fine (fL), subangular, strong brown (7.5 YR 5/6); clay, common; soil structure, clear boundary.

Sand, quartz, medium (mL), subrounded, strong brown (7.5 YR 5/6) and yellow (10 YR 7/6); clear boundary.

Sand, quartz, very fine (vfL), mixed strong brown (7.5 YR 5/6) and light yellowish brown (10YR 6/4); clay, abundant; gradual boundary.

Sand, quartz, very fine (vfL), brow'nish yellow (10 YR 6/8); clear boundary.

$\begin{array}{ll}3.8 & 1.5 \\ 6.6 & 2.8\end{array}$

Clay, light brownish gray ( 2.5 Y 6/2) with yellowish brown (10 YR 5/8) mottles; sand, quartz, very fine (vfU), abundant; clear boundary.

Clay, light gray (10YR 6/1); sand, quartz, very fine (vfU), common.

Clay, dark gray $(5 Y 4 / 1)$; sand, very fine (vfU), minor; clear boundary.

Sand, quartz, fine (fU), subrounded, dark gray (5Y 4/1); silt, minor.

Sand, quartz, medium ( $\mathrm{mL}$ ) and fine (fU), subrounded, dark gray (5Y 4/1); silt, common; clear boundary.

Sand, quartz, very fine (vfU), dark gray (5 Y 4/1); silt, abundant.

Sand, quartz, very fine (vfU), olive gray ( 5 Y 4/2); clay, common; bivalve shells at $26.0 \mathrm{ft}$.

Sand, quartz, medium $(\mathrm{mL})$ to fine (fU and $\mathrm{fL}$ ), subangular, dark gray (5 Y 4/1).

Sand, quartz, fine (fU), subrounded; dark gray (5 Y 4/1); silt and clay, common; gradual boundary.

Silt, dark gray (5 Y 4/1); sand, quartz, very fine (vfU), common.

Clay, dark gray ( 5 Y 4/1); silt, abundant; shells, bivalves, $41.0-42.0 \mathrm{ft}$, minor.

Clay, dark olive ( 5 Y $3 / 2)$; silt, common; shells, trace, $44.0-47.0 \mathrm{ft}$; shells, abundant, $47.0-49.0 \mathrm{ft}$.

Clay, dark olive gray (5 Y 3/2); bivalve shells, whole and fragments, abundant; shells appear in distinct beds.

Clay, dark olive gray ( 5 Y $3 / 2)$; silt, common; bivalve shells, whole and halves, fragments, abundant; massive.

Clay, dark olive gray (5 Y $3 / 2$ ); silt, abundant; sand, quartz, very fine (vfU), minor; bivalve shells, whole and fragments, common; jointed.

Clay, dark gray ( 5 Y 4/1); silt, common; bivalve and gastropod shells, mostly fragments $(<5 \mathrm{~mm})$, common. rippled structure.

Clay, dark gray (5Y 4/1); silt, abundant; bivalve shell fragments $(<1 \mathrm{~cm})$, minor; rippled structure.

Clay, dark gray (5 Y 4/1) with olive (5Y 5/3)) mottles; silt, common; shells, bivalves, fragments, minor.

Clay, dark olive gray ( 5 Y 3/2) with olive mottles (5 Y 5/3); silt, common; shell fragments, bivalves, minor.

Clay, dark olive gray $(5 Y 3 / 2)$ with olive (5Y 4/4) mottles; silt, common. 
Table 8.--Lithologic logs for well-cluster and borehole sites

[Codes enclosed in parentheses refer to the Munsell Soil Color Charts (1975)]

$\begin{array}{llllll}\text { Term } & \text { Grain size (microns): } & \text { Term } & \text { Grain size (microns) : } & \text { Relative abundance descriptors: } \\ \mathrm{vcU}= & 1,410-2,000 & \mathrm{~mL} & =250-350 & \text { Abundant }>30 \% \\ \mathrm{vcL}= & 1,000-1,410 & \mathrm{fU} & =177-250 & \text { Common }>15 \% \text { and }<30 \% \\ \mathrm{cU}= & 710-1,000 & \mathrm{fL} & =125-177 & \text { Minor }>1 \% \text { and }<15 \% \\ \mathrm{cL}= & 500-710 & \mathrm{vfU} & =88-125 & \text { Trace }<1 \% \\ \mathrm{mU}= & 350-500 & \mathrm{vfL} & =62-88 & \end{array}$

\begin{tabular}{lll}
\hline Lithology & $\begin{array}{l}\text { Depth } \\
\text { (feet) }\end{array}$ & $\begin{array}{l}\text { Thickness } \\
\text { (feet) }\end{array}$ \\
\hline
\end{tabular}

Well cluster site 8-Continued

Clay, interbedded dark olive gray ( 5 Y $3 / 2$ ) and olive ( 5 Y 4/4); beds are

$0.5 \mathrm{~cm}$ thick and more pronounced at base of core; silt, common, mixed with clay and occurring as isolated, thin $(<1.0 \mathrm{~mm})$ beds.

Clay, interbedded dark gray (5 Y 4/1), olive gray (5 Y $5 / 2)$, and olive ( 5 Y $4 / 4$ );

silt, common; beds are pronounced $(0.5 \mathrm{~mm}$ thick) and separated by thin silt beds.

Clay, dark gray (5 Y 4/1) and olive gray (5 Y 5/2); sand, quartz, very fine (vfL);

104.0 common.

Clay, olive gray (5 Y 4/2); sand, quartz, coarse, abundant; clear boundary.

106.5

Clay, dark gray (5 Y 3/1); sand, quartz, medium (mU); clay, light gray

109.0

(5 Y 7/2); wood, fragments.

Clay, gray (5Y 4/1); sand, quartz, medium (mU); pebbles, trace; wood, fragments.

Sand, quartz, coarse (cU), gray (5 Y 4/1); gravel, abundant; clay, dark olive gray

$11+.0$

$(5 Y 3 / 2)$ with olive $(5 Y 4 / 1)$ mottles. 
Table 8.--Lithologic logs for well-cluster and borehole sites

[Codes enclosed in parentheses refer to the Munsell Soil Color Charts (1975)]

$\begin{array}{llllll}\text { Term } & \text { Grain size (microns) : } & \text { Term } & \text { Grain size (microns) : } & \text { Relative abundance descri } \\ \mathrm{vcU}=1,410-2,000 & \mathrm{~mL} & = & 250-350 & \text { Abundant }>30 \% \\ \mathrm{vcL}= & 1,000-1,410 & \mathrm{fU} & =177-250 & \text { Common }>15 \% \text { and }<30 \% \\ \mathrm{cU}= & 710-1,000 & \mathrm{fL} & =125-177 & \text { Minor }>1 \% \text { and }<15 \% \\ \mathrm{cL}= & 500-710 & \mathrm{vfU} & =88-125 & \text { Trace }<1 \% \\ \mathrm{mU}= & 350-500 & \mathrm{vfL} & =62-88 & \end{array}$

\begin{tabular}{lll}
\hline Lithology & Depth & $\begin{array}{l}\text { Thickness } \\
\text { (feet) }\end{array}$ \\
\end{tabular}

Well cluster site 9

Soil, sandy loam, dark yellowish-brown (10 YR 4/4).

$1.0 \quad 1.0$

Sand, quartz, fine (fU), light yellowish-brown (10 YR 6/4); clay, minor; clear boundary.

Sand, quartz, medium (mU), subrounded, mottled, brownish-yellow (10 YR 6/4) and brownish gray $(10$ YR 6/2).

Sand, quartz, very fine (vfU), mottled, brownish-yellow (10 YR 6/4) and brownish gray $(10$ YR $6 / 2)$.

Sand, quartz, medium ( $\mathrm{mL}$ ), subrounded, light yellowish-brown (10 YR 6/4).

Sand, quartz, fine (fL), mottled reddish-yellow (10 R 7/8) and light gray (10 YR 7/2); pebbles $(1.0 \mathrm{~cm})$ at $14.5 \mathrm{ft}$; abrupt boundary.

Sand, quartz, very fine (vfU), gray (5Y $5 / 1)$; clear boundary.

Sand, quartz, very fine (vfU), gray $(5 Y 5 / 1)$; clay, abundant, finely bedded; clear boundary.

Sand, quartz, fine (fU), dark greenish-gray ( 5 GY 4/1); gradual boundary.

Sand, quartz, fine (fU), dark gray (N4); interbedded with thin organic beds $(2.0-3.0 \mathrm{~cm}$ thick).

Sand, quartz, fine and very fine ( $\mathrm{fL}$ and vfU), dark gray (5 $\mathrm{Y} 4 / 1)$.

Sand, quartz, very fine (vfU), dark gray $(5 Y 4 / 1)$; silt, minor.

Sand, quartz, medium ( $\mathrm{mL}$ ) and fine (fU), dark gray (5Y 4/1); silt, trace; gradual boundary.

Clay, dark gray $(5 Y 4 / 1)$; silt, common.

Clay, dark gray ( 5 Y 4/1); silt, common; bedding ( $<1.0 \mathrm{~mm}$ thick); clay blob, white (10 YR 8/1); burrow, sand filled, sand, quartz, very fine (vfU), yellow (10 YR 2/6).

Clay, dark gray (5Y 4/1); silt, common.

Clay, dark gray $(5 Y 4 / 1)$; silt, common; massive.

Clay, dark gray $(5 Y 4 / 1)$; silt, common; fractured.

Clay, dark gray ( 5 Y $4 / 1)$; silt, common; bivalve shells, bedded, minor, unevenly distributed.

Clay, dark gray ( 5 Y 4/1); silt, common; bivalve shells, bedded, minor, evenly distributed.

Clay, dark gray (5 Y 4/1); silt, common; bivalve shells, bedded, minor; unevenly distributed. Clay, dark gray ( 5 Y $4 / 1$ ); silt, common; shell fragments, common, thinly bedded.

Clay, mottled, dark gray (5Y 4/1) and black (10 YR 2/1); silt, trace.

Clay, dark gray ( 5 Y 4/1); silt, common; clear boundary.

Sand, quartz, fine ( $\mathrm{fL}$ ), subangular; silt, common; organic material, trace.

No sample.

Sand, quartz, fine (fU), subangular, dark gray ( $5 Y 4 / 1)$; top of core is well bedded; sand, quartz, subangular, mixed medium (mU) and coarse (cU), dark gray (5 Y 4/1).

Sand, quartz, mixed and interbedded, medium (mU) and coarse (cU) (10 YR 6/1); silt beds $(1.0 \mathrm{~cm}$ thick), dark gray (5 Y 4/1); abrupt boundary.

Clay, dark gray $(5 Y 4 / 1)$ with large olive $(5 Y 5 / 3)$ mottles; silt, common; pebbles $(1.0-2.0 \mathrm{~cm})$, quartz, rounded, trace; wood fragments, common; clear boundary.

Clay, dark gray $(5 Y 4 / 1)$ with large olive $(5 Y 5 / 3)$ mottles, well bedded; pebbles $(1.0-2.0 \mathrm{~cm})$, quartz, rounded, trace; wood fragments, common; beds of sand, quartz, coarse (cU), subangular, comnon; abrupt boundary.

$\begin{array}{ll}74.0 & 1.0 \\ 79.0 & 5.0 \\ 79.1 & .1 \\ 82.3 & 3.2 \\ 83.0 & .7\end{array}$


Table 8.--Lithologic logs for well-cluster and borehole sites

[Codes enclosed in parentheses refer to the Munsell Soil Color Charts (1975)]

$\begin{array}{lcllll}\text { Term } & \text { Grain size (microns) : } & \text { Term } & \text { Grain size (microns) : } & \text { Relative abundance descriptors: } \\ \mathrm{vcU}=1,410-2,000 & \mathrm{~mL} & = & 250-350 & \text { Abundant }>30 \% \\ \mathrm{vcL}=1,000-1,410 & \mathrm{fU} & = & 177-250 & \text { Common }>15 \% \text { and }<30 \% \\ \mathrm{cU}= & 710-1,000 & \mathrm{fL} & = & 125-177 & \text { Minor }>1 \% \text { and }<15 \% \\ \mathrm{cL}= & 500-710 & \mathrm{vfU} & = & 88-125 & \text { Trace }<1 \% \\ \mathrm{mU}= & 350-500 & \mathrm{vfL} & =62-88 & \end{array}$

\begin{tabular}{lll}
\hline & Depth & Thickness \\
Lithology & (feet) & (feet)
\end{tabular}

\section{Well cluster site 10}

Sand, fine (fU), subrounded, dark yellowish brown (10 YR 4/2); silt, abundant; organic material, abundant; $2.5 \mathrm{~cm}$ lens of burnt wooden material; abrupt boundary.

Sand, fine (fU), subrounded, light yellow brown (2.5Y 6/4); silt, minor; clear boundary.

Sand, medium ( $\mathrm{mL}$ ), subrounded, reddish yellow (7.5 YR 6/6); silt, minor; clear boundary.

Sand, fine and medium (fU and $\mathrm{mL}$ ), subrounded, mottled brown (10 YR 5/3), reddish yellow (7.5 YR 6/6), and light gray (10 YR 7/2).

Sand, quartz, medium $(\mathrm{mL})$, mottled reddish yellow (7.5 YR 6/6) and light gray (10 YR 7/2); clay, abundant.

Sand, quartz, medium (mL), mottled reddish yellow (7.5 YR 6/6) and gray (10 YR 5/1); abrupt boundary.

Clay, dark gray (N4); sand, fine (fL), abundant.

Sand, quartz, fine (fU), subangular, mixed light gray ( 5 Y $6 / 1)$ and light olive gray $(5 Y 6 / 2)$.

Sand, quartz, very fine (vfU), olive gray (5Y $4 / 1$ ); silt, minor.

No sample.

Sand, quartz, very fine (vfU), olive gray ( $5 Y$ 4/1); silt, minor; mica, trace; faint, thin bedding.

Clay, olive gray (5Y 4/1); silt, abundant; mica, trace.

Clay, olive gray ( 5 Y 4/1); silt, common; wood, fragments, trace; faint, thin bedding.

Clay, olive gray ( $5 Y 3 / 2$ ); sand, quartz, very fine (vfU), minor; breaks along fractures into $1.0-2.0 \mathrm{~cm}$ angular, blocky fragments; abrupt boundary.

Clay, olive gray ( 5 Y $3 / 2$ ); silt, common; massive; imprints of bivalve shells, minor.

$\begin{array}{rr}13.0 & .7 \\ 13.6 & .6 \\ 19.0 & 5.4 \\ & \\ 22.0 & 3.0 \\ 24.0 & 2.0 \\ & \\ 29.0 & 5.0 \\ & \\ 34.0 & 5.0 \\ 39.0 & 5.0 \\ 42.2 & 3.2 \\ & \\ 44.0 & 1.8 \\ & \\ 48.0 & 4.0 \\ & \\ 49.0 & 1.0 \\ & \\ 54.0 & 5.0 \\ 59.0 & 5.0 \\ 63.5 & 4.5 \\ & .5 \\ 64.0 & 3.0 \\ & .8 \\ 67.0 & \\ 67.2 & \\ 76.0 & \end{array}$

Clay, olive gray ( 5 Y $3 / 2)$; silt, common; massive; small $(0.5 \mathrm{~mm})$ bivalve shell fragments, common; clear boundary.

Clay, olive gray ( 5 Y $3 / 2)$; silt, common; massive; small $(0.5 \mathrm{~mm})$, bivalve shell fragments, common; breaks into $1-2 \mathrm{~cm}$ angular blocks.

Clay, olive gray $(5 Y 3 / 2)$; silt, common; bivalve shells, whole and parts $(<3.0 \mathrm{~cm})$, minor;

Clay, olive gray ( 5 Y $3 / 2)$; silt, common; massive.

Clay, olive gray (5 Y 4/1); silt, common; massive; clear boundary.

Clay, olive gray ( 5 Y 4/1); silt, common; massive; breaks along beds parallel to land surface; clear boundary.

Clay, olive gray ( 5 Y 4/1); silt, common; massive; abrupt boundary.

Sand, quartz, coarse (cL), olive gray (5 Y 4/1); gravel, quartz, $1.0-2.0 \mathrm{~cm}$.

76.0

7

.6

\section{4}

3.0

5.0

5.0

0

5

.5

3.0

8.8 
Table 8.--Lithologic logs for well-cluster and borehole sites

[Codes enclosed in parentheses refer to the Munsell Soil Color Charts (1975)]

$\begin{array}{llllll}\text { Term } & \text { Grain size (microns) : } & \text { Term } & \text { Grain size (microns) : } & \text { Relative abundance descriptors: } \\ \mathrm{vcU}=1,410-2,000 & \mathrm{~mL} & =250-350 & \text { Abundan }>30 \% \\ \mathrm{vcL}=1,000-1,410 & \mathrm{fU} & =177-250 & \text { Common }>15 \% \text { and }<30 \% \\ \mathrm{cU}= & 710-1,000 & \mathrm{fL} & =125-177 & \text { Minor }>1 \% \text { and }<15 \% \\ \mathrm{cL}= & 500-710 & \mathrm{vfU} & =88-125 & \text { Trace }<1 \% \\ \mathrm{mU}= & 350-500 & \mathrm{vfL} & =62-88 & \end{array}$

\section{Well cluster site 11}

Soil, dark yellowish brown (10 YR 4/2); silt loam texture; burned wood ( $15 \mathrm{~cm}$ thick); gradual boundary.

Sand, quartz, fine ( $f L$ ), subrounded; light olive brown ( 2.5 Y 5/8); clay, minor; clear boundary.

Sand, quartz, very fine ( $v f U)$, mottled yellowish brown (10 YR 5/8) and light gray (10 YR 7/1); clay, common; gradual boundary.

Sand, quartz, medium ( $\mathrm{mU}$ ) and fine (fU), subangular, grayish brown (2.5 Y $5 / 2)$; gradual boundary.

Sand, quartz, very fine (vfU), light brownish gray ( 2.5 Y $5 / 2)$ grading downward to light olive brown (2.5 Y 5/6); clay, common; abrupt boundary.

Sand, quartz, very fine (vfU), gray ( 5 Y $5 / 1$ ); clay and silt, minor; gradual boundary.

Sand, quartz, fine (fU); light gray $(5 Y 6 / 1)$; mica, trace; silty zone, thin $(2.5 \mathrm{~cm})$ at $19.5 \mathrm{ft}$, dark olive gray $(5 Y 3 / 2)$; contains abundant leaf remains.

Sand, quartz, medium ( $\mathrm{mL}$ ), subrounded; very dark gray ( 5 Y $3 / 1$ ); mica, trace; abrupt boundary.

Clay, very dark gray (5 $Y 4 / 1$ ); sand, quartz, very fine (vfU), minor; clay coatings on fractured surfaces, olive gray (5Y 4/2).

Sand, quartz, fine (fU); very dark gray ( 5 Y $3 / 1)$.

Sand, quartz, very fine (vfU), dark olive gray (5 Y 3.2); silt, common (abundant 28-29ft); wood fragments, minor.

Clay, dark olive gray ( 5 Y $3 / 2)$; silt, common.

Clay, dark olive gray ( 5 Y $3 / 2)$; silt, common; shell imprints $\left(\mathrm{CaCO}_{3}\right.$ absent), minor.

Clay, dark olive gray (5Y $3 / 2)$; silt, minor; casts and molds of shells; clear boundary.

Clay, dark olive gray ( 5 Y $3 / 2)$; silt, common; clay coatings on fractures; breaks along fractures; shell fragments, minor; cemented zones, minor; clear boundary.

Clay, dark gray ( $5 Y 3 / 1)$; massive; bivalve shells, common.

Clay, dark gray (5 Y 4/1); silt, common; bivalve shells, whole, abundant.

Clay, dark olive gray $(5 Y 3 / 2)$; silt, common; bivalve shells, common.

Clay, dark olive gray ( 5 Y $3 / 2)$; silt, abundant; massive.

Clay, dark olive gray ( 5 Y $3 / 2)$; silt, abundant; massive.

Clay, dark olive gray (5Y $3 / 2$ ); silt, abundant; massive. 
Table 8.--Lithologic logs for well-cluster and borehole sites

[Codes enclosed in parentheses refer to the Munsell Soil Color Charts (1975)]

\begin{tabular}{|c|c|c|c|c|c|c|}
\hline Term & & Grain size (microns) : & Term & & ain size (microns) : & Relative abundance descriptors: \\
\hline vcU & $=$ & $1,410-2,000$ & $\mathrm{~mL}$ & $=$ & $250-350$ & Abundant $>30 \%$ \\
\hline $\mathrm{vcL}$ & $=$ & $1,000-1,410$ & $\mathrm{fU}$ & $=$ & $177-250$ & Common $>15 \%$ and $<30 \%$ \\
\hline $\mathrm{cU}$ & $=$ & $710-1,000$ & $\mathrm{IL}$ & $=$ & $125-177$ & Minor $>1 \%$ and $<15 \%$ \\
\hline $\mathrm{cL}$ & $=$ & $500-710$ & $v f U$ & $=$ & $88-125$ & Trace $<1 \%$ \\
\hline $\mathrm{mU}$ & $=$ & $350-500$ & $\mathrm{vfl}$ & $=$ & $62-88$ & \\
\hline
\end{tabular}

\section{Well cluster site 12}

Soil, silt loam, predominately sand, quartz, fine (fU), subrounded, dark brown (10 YR 3/3); silt, common; clay, trace; plant roots, abundant; clear boundary.

Sand, quartz, very fine (vfU), olive brown ( 2.5 Y 4/4); silt, trace; abrupt boundary.

Sand, quartz, very fine (vfL), mottled brown (10 YR 5/3) and yellowish-brown (10 YR 5/6); clay, common; gradual boundary.

Sand, quartz, very fine (vfL), mottled light gray $(10 Y R 7 / 2)$ and yellowish-brown (10 YR 5/8); clear boundary.

Sand, quartz, medium (mL), grayish brown ( 2.5 Y $5 / 2$ ); clear boundary.

Sand, quartz, medium (mL), strong brown (7.5 YR 5/6); mica, common; interbedded organic zones.

Sand, quartz, very fine (vfU), light olive gray ( 5 Y $6 / 2$ ); silt, common; abrupt boundary.

Sand, quartz, very fine (vfU), dark gray $(5 Y 4 / 1)$; silt, common.

Sand, quartz, fine (fU), subrounded, gray ( $5 Y 5 / 1)$.

Sand, quartz, fine (fL), subrounded, dark gray ( 5 Y 4/1); mica, minor; gradual boundary.

$\begin{array}{rr}0.3 & 0.3 \\ 1.5 & 1.2 \\ 2.4 & .9 \\ 3.8 & 1.4 \\ & \\ 5.5 & 1.7 \\ & \\ 9.0 & 3.5 \\ & \\ 11.3 & 2.3 \\ 14.0 & 2.7 \\ 19.0 & 5.0 \\ 23.0 & 4.0 \\ & \\ 24.0 & 1.0 \\ 29.0 & 5.0 \\ 34.0 & 5.0 \\ & \\ 38.5 & 4.5 \\ 39.0 & .5 \\ 44.0 & 5.0 \\ & \\ 49.0 & 5.0 \\ 54.0 & 5.0 \\ 59.0 & 5.0 \\ 63.5 & 4.5 \\ 64.0 & .5 \\ 70.0 & \\ & \\ & \\ & \\ & \\ & \end{array}$

Sand, quartz, fine (fL), subroumded, olive gray $(5 Y 5 / 2)$.

Sand, quartz, very fine (vfU), dark gray $(5 Y 4 / 1)$.

Clay, very dark gray (5 Y $3 / 1)$; silt, abundant; wood fragments, minor $(1.0-2.0 \mathrm{~cm}$ at $33.0 \mathrm{ft})$; conchoidal fracture.

Clay, dark gray (5 Y 4/1); silt, minor; massive; abrupt boundary.

Clay, olive gray ( 5 Y 5/2); shells, whole and fragments, abundant; very hard.

Clay, dark gray (5 Y 4/1); silt, common; highly fractured at 40.0-43.0 ft, sample crumbles into $1.0-2.0 \mathrm{~cm}$ fragments.

Clay, dark gray (5Y 4/1); silt, common; massive.

Clay, dark gray (5Y 4/1); silt, common; massive.

Clay, dark gray $(5 Y 4 / 1)$; silt, abundant; massive.

Clay, dark gray (5 Y $4 / 1)$; silt, abundant; massive.

Sand, quartz, medium ( $\mathrm{mL}$ and $\mathrm{mU}$ ) to coarse ( $\mathrm{CL}$ ), subangular, dark gray $(5 \mathrm{Y} 4 / 1)$; silt, minor.

No sample 